Aus dem Institut für Molekulare Onkologie

Prof. Dr. med. M. Dobbelstein

der Medizinischen Fakultät der Universität Göttingen

\title{
Der Tumorsuppressor p53 reguliert HSF1 im Modell des kolorektalen Karzinoms
}

\author{
INAUGURAL-DISSERTATION \\ zur Erlangung des Doktorgrades \\ der Medizinischen Fakultät der \\ Georg-August-Universität zu Göttingen
}

vorgelegt von

Adrian Stender

aus

Duderstadt

Göttingen 2020 
Dekan:

\section{Betreuungsausschuss}

Betreuer:

Ko-Betreuer:

\section{Prüfungskommission}

Referent:

Ko-Referent:

Drittreferent:

Datum der mündlichen Prüfung:
Prof. Dr. med. W. Brück

Prof. Dr. med. M. Dobbelstein

Prof. Dr. med. J. Gaedcke

Prof. Dr. med. M. Dobbelstein

Prof. Dr. med. J. Gaedcke

Prof. Dr. mult. T. Meyer

15.07.2021 
Hiermit erkläre ich, die Dissertation mit dem Titel "Der Tumorsuppressor p53 reguliert HSF1 im Modell des kolorektalen Karzinoms" eigenständig angefertigt und keine anderen als die von mir angegebenen Quellen und Hilfsmittel verwendet zu haben.

Göttingen, den 


\section{Inhaltsverzeichnis}

Abbildungsverzeichnis ................................................................................. III

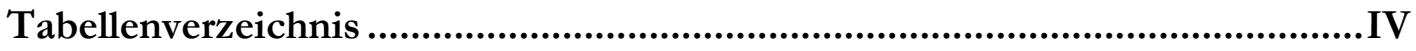

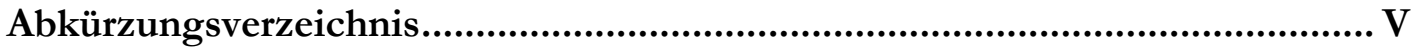

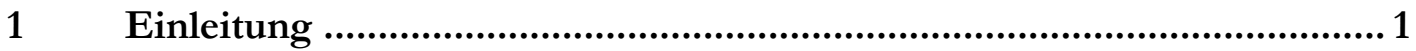

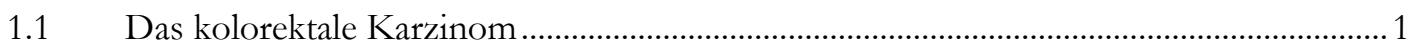

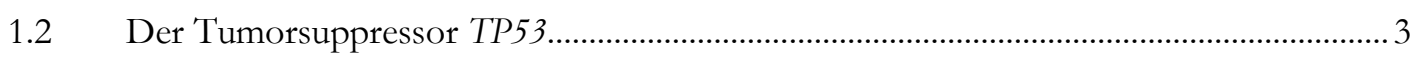

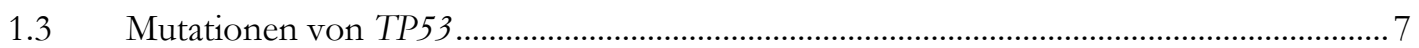

1.4 Das stressinduzierte Chaperone-System und der heat-shock factor 1 .................................... 7

1.5 HSF1 in der Rolle eines Non-Onkogens......................................................................11

1.6 Zielsetzung dieser experimentellen Arbeit …………………………………………......13

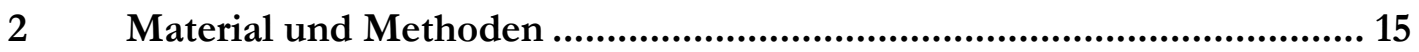

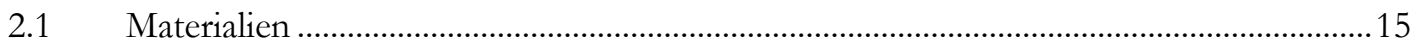

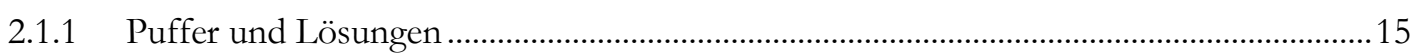

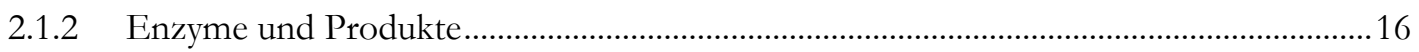

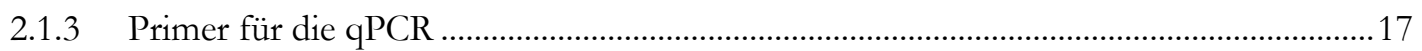

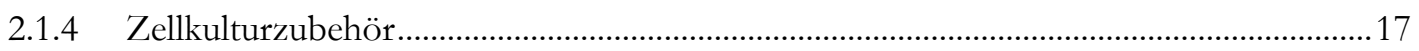

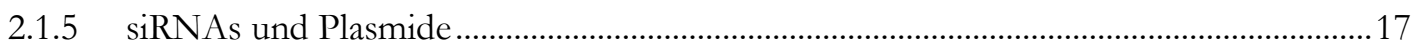

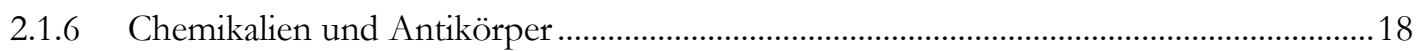

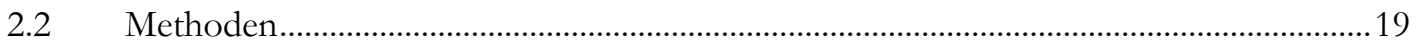

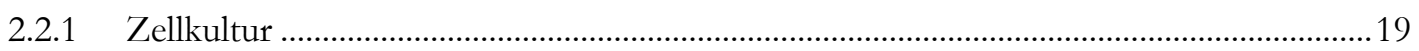

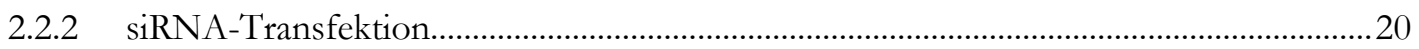

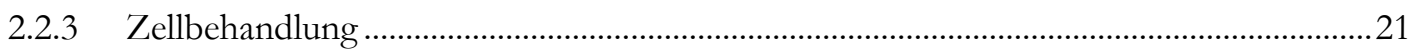

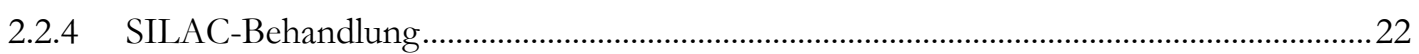

2.2.5 Proteinextraktion aus kultivierten Zellen für Western-Blot-Analysen..............................22

2.2.6 Konzentrationsbestimmung eines Proteinlysats............................................................23

2.2.7 Proteinextraktion aus kultivierten Zellen für Ko-Immunpräzipitation ...........................23

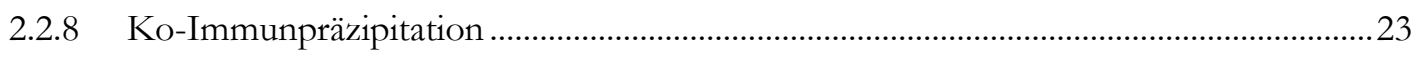

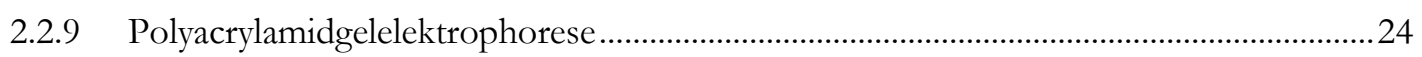

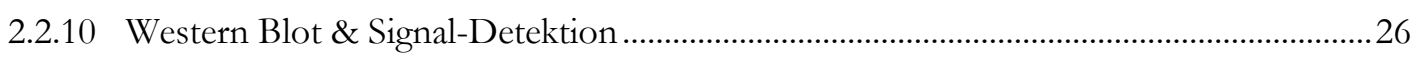

2.2.11 mRNA-Isolierung aus kultivierten Zellen mit Konzentrationsbestimmung ...................27

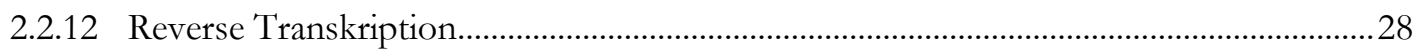

2.2.13 Quantitative real-time PCR ...................................................................................................22

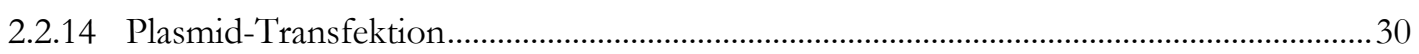

2.2.15 Hitzeschockbehandlung von humanen Zellen ................................................................ 31

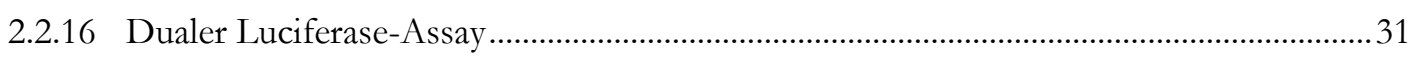

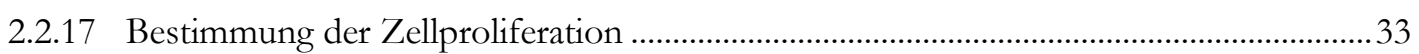

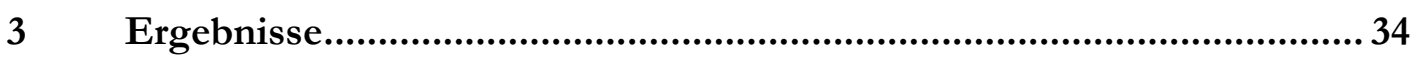

3.1 Eine p53-Aktivierung führt zu einer Veränderung der HSF1-Phosphorylierung............34 
3.2 Eine p53-Aktivierung hemmt die Expression von HSF1-regulierten Genen ..................35

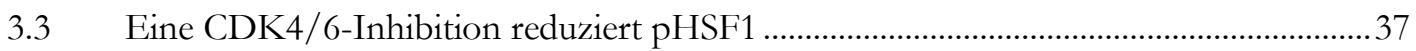

3.4 Eine CDK4/6-Inhibition hemmt die Expression von HSF1-regulierten Genen...........42

3.5 Überprüfung der HSF1-Aktivität in einem dualen Luciferase-Assay ...............................43

3.6 Die Untersuchung von HSF1-überexprimierenden HCT116-Zellen.................................45

3.7 Zwischen CDK4 und HSF1 findet keine Komplexbildung statt ......................................4

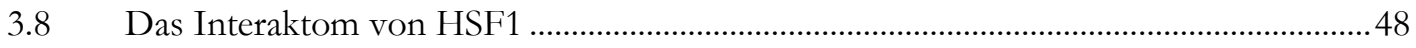

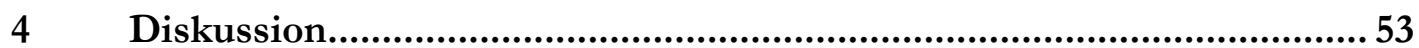

4.1 Identifizierung möglicher HSF1-Regulatoren................................................................53

4.2 Der Einfluss von wildtypischem p53 auf das tumorfördernde HSF1-System.................55

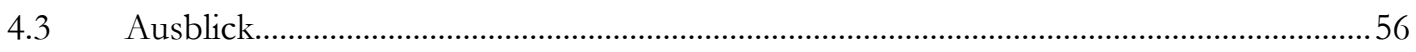

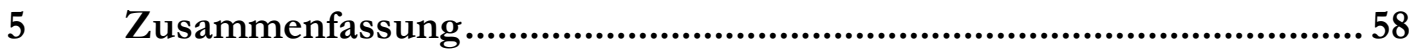

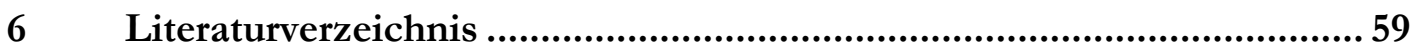




\section{Abbildungsverzeichnis}

Abbildung 1: Struktur von p53................................................................................................

Abbildung 2: p21 inhibiert CDKs und vermittelt einen p53-abhängigen Zellzyklusarrest. ......... 4

Abbildung 3: Die Freisetzung von p53 aus dem Komplex mit MDM2 ermöglicht eine p53-

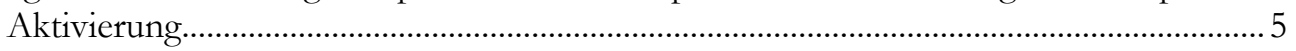

Abbildung 4: Übersicht ausgewählter, p53-regulierter Gene........................................................ 6

Abbildung 5: HSP90 im stressinduzierten Chaperone-Netzwerk. ................................................ 8

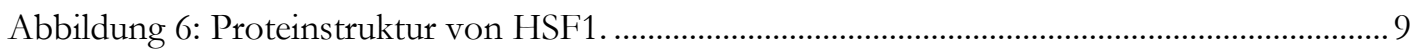

Abbildung 7: HSF1-Trimerisierung und Bindung an HSEs....................................................... 10

Abbildung 8: Modifizierungen beeinflussen die Aktivität von HSF1 ............................................11

Abbildung 9: Beispielhafte Darstellung des Messprinzips zur Ermittlung der Zellkonfluenz...33

Abbildung 10: p53-Aktivierung führt zu einer Reduktion von pHSF1..........................................34

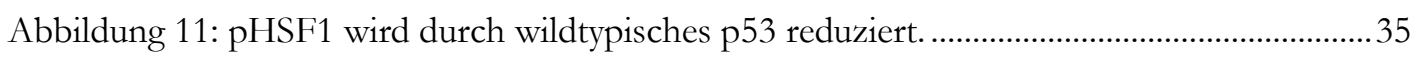

Abbildung 12: Analyse ausgewählter HSF1-Zielgene................................................................... 36

Abbildung 13: Expression von HSF1-regulierter Zielgene nach p53-Aktivierung in HCT116-

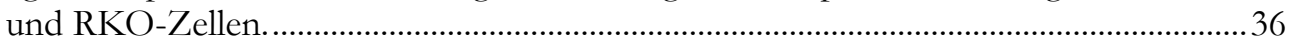

Abbildung 14: Die Nutlin-3a-vermittelte Repression von HSF1 ist abhängig von

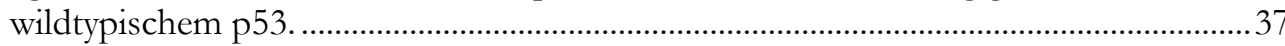

Abbildung 15: CDKN1 $A$ wird durch p53-Aktivierung durch Nutlin-3a stark induziert.............38

Abbildung 16: Die Nutlin-3a-vermittelte Repression von HSF1 ist abhängig von p21..............39

Abbildung 17: CDK4/6-Inhibition reduziert pHSF1 ................................................................. 40

Abbildung 18: CDK4/ 6 vermittelt die p53-abhängige Reduktion von pHSF1...........................41

Abbildung 19: Eine p53-Aktivierung bzw. CDK4/6-Inhibition führen reproduzierbar zu einer

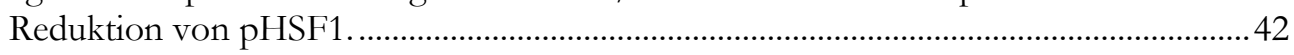

Abbildung 20: Expression von HSF1-reguliertern Zielgenen nach CDK4/6-Inhibition in HCT116- und RKO-Zellen............................................................................................4

Abbildung 21: Hitzeschockbehandlung führt zur Steigerung der transkriptionellen Aktivität

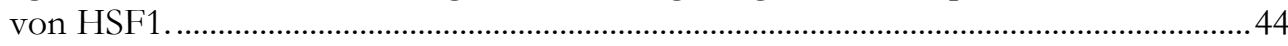

Abbildung 22: Die HSF1-abhängige relative Luciferase-Aktivität wird durch p53 und CDK4/6

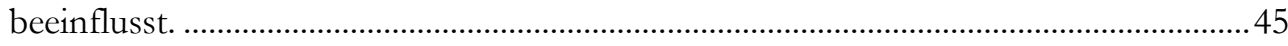

Abbildung 23: HSF1-überexprimierende Klone zeigen eine Reduktion von pHSF1 nach p53-

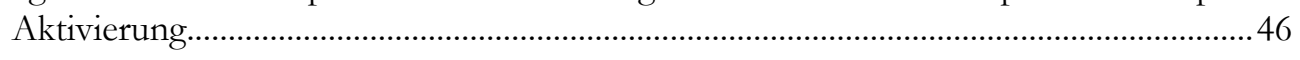

Abbildung 24: Expression HSF1-regulierter Zielgene in HSF1c1 .................................................46

Abbildung 25: Eine HSF1-Überexpression hat keinen Einfluss auf die Zellproliferation..........47

Abbildung 26: Eine Bindung von CDK4 und HSF1 ist nicht nachweisbar.................................4 48

Abbildung 27: Überprüfung der Behandlung mit Nutlin-3a vor massenspektrometrischer Analyse des HSF1 Interaktoms. ...................................................................................... 49

Abbildung 28: Vergleich zweiter Antikörper zur CoIP.................................................................4

Abbildung 29: Darstellung des spezifischen HSF1-Interaktoms..................................................51

Abbildung 30: Darstellung des HSF1-Interaktoms nach Zellbehandlung.....................................52 


\section{Tabellenverzeichnis}

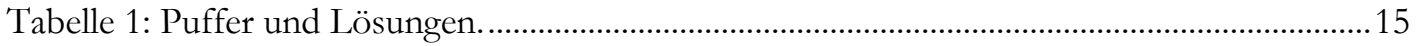

Tabelle 2: Enzyme und Produkte für Proteinbiochemie..................................................................16

Tabelle 3: Enzyme und Produkte für reverse Transkription \& qPCR.........................................16

Tabelle 4: Reagenzien und Chemikalien für den dualen Luciferase-Assay. ................................16

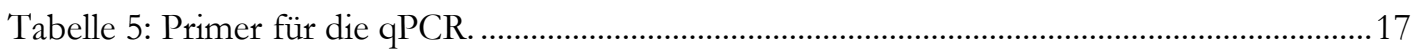

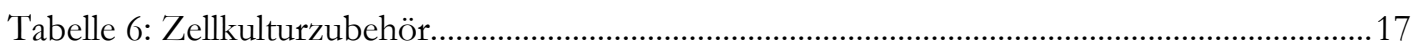

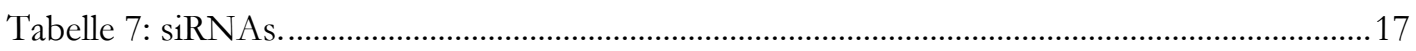

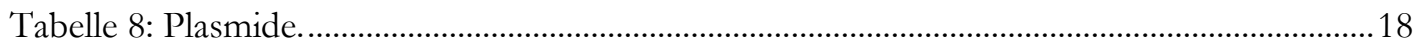

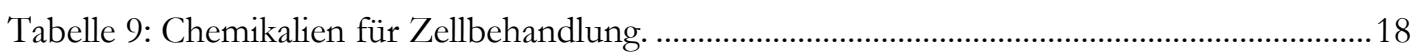

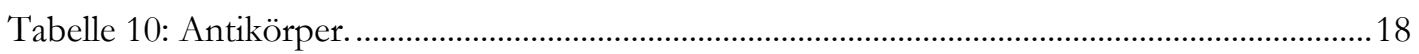

Tabelle 11: Human Karzinomzelllinien aus Kolonkarzinomen....................................................19

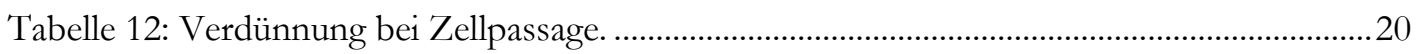

Tabelle 13: Zellzahl für siRNA-Transfektion in 12er-Multiwellplatten......................................21

Tabelle 14: Zellzahl für Behandlung mit Inhibitoren in 12er-Multiwellplatten..........................21

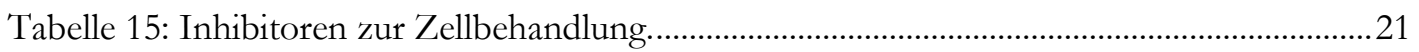

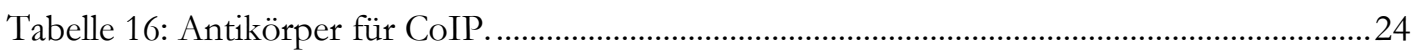

Tabelle 17: Zusammensetzung der Polyacrylamidgele. ....................................................................25

Tabelle 18: Antikörper für Western Blots. ....................................................................................2 27

Tabelle 19: Zusammensetzung der Reaktionslösungen für cDNA-Synthese.............................29

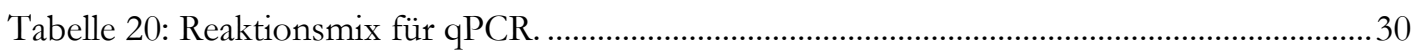

Tabelle 21: Schema für die Transfektion mit Plasmid-DNA. .........................................................3

Tabelle 22: Schema für Zellbehandlung nach erfolgter Transfektion..........................................32

Tabelle 23: Messprotokoll für den dualen Luciferase-Assay. .............................................................32

Tabelle 24: Überblick über vorbereitende Schritte für die CoIPs zur massenspektrometrischen 


\section{Abkürzungsverzeichnis}

APC adenomatous poliposis coli

BSA bovines Serum-Albumin

$\mathrm{CDK}$ Cyclin-abhängige Kinase cDNA komplementäre DNA

CoIP Ko-Immunopräzipitation

$\mathrm{Ct}$ cycle threshold

DMSO Diemethylsulfoxid

EGFR epidermal growth factor receptor

ERK extracellular signal related kinase

FCS fetales Kälber-Serum

HER2 buman epidermal growth factor receptor 2

HSE heat-shock element

HSF1 heat-shock factor 1

HSF1c1 HCT116 LentiHSF1-Klon 12

HSF1c2 HCT116 LentiHSF1-Klon 21

HSP heat-shock protein

KRAS kirstin rat sarcoma viral oncogene homolog

MAPK mitogen-activated protein kinase

MDM2 mouse double minute 2

MEK mitogen-activated protein kinase kinase mRNA messenger ribonucleic acid mTOR mammalian target of rapamycin

ORFc1 HCT116 LentiORF-Klon 13

ORFc2 HCT116 LentiORF-Klon 14

PAS Protein A Sepharose PBS phosphat-buffered saline PI3K Phosphoinositid-3-Kinase qPCR quantitative real-time Polymerasekettenreaktion $\mathrm{Rb}$ Retinoblastoma Protein RPM revolutions per minute shRNA short hairpin ribonucleic acid stable isotope labeling by amino acids in cell culture short interfering ribonucleic acid small ubiquitin-like modifier 


\section{$1 \quad$ Einleitung}

\subsection{Das kolorektale Karzinom}

Bösartige Neubildungen des Kolon und Rektum gehören in Deutschland zu den häufigsten Karzinomen. Dabei waren Karzinome des Darms 2016 bei Männern die dritthäufigste bzw. bei Frauen zweithäufigste Krebsneuerkrankung. In Hinblick auf die Krebssterblichkeit stellten Karzinome des Darms in derselben Erhebung die dritthäufigste Krebstodesursache dar. Etwa zwei Drittel aller bösartigen Neubildungen des Darms sind dabei Karzinome des Dick- sowie Enddarms (Zentrum für Krebsregisterdaten im Robert Koch-Institut 2019). Hiervon wiederum sind etwa zwei Drittel Kolon- und ein Drittel Rektumkarzinome (Siegel et al. 2018).

Trotz der Kontinuität des Darms sind zwischen Karzinomen des Kolon und Rektum distinkte Unterschiede beschrieben worden (Hong et al. 2012). Je nach Lokalisation unterscheidet sich die therapeutische Strategie sowie die Prognose hinsichtlich Metastasierung und Überleben (Sauer et al. 2004; Riihimäki et al. 2016; van der Sijp et al. 2016). Für Rektumkarzinome konnten molekulare Prädikatoren der Prognose identifiziert werden (Liersch et al. 2009; Hu et al. 2018). Die dabei gültigen Prinzipien finden trotz der Unterschiede zwischen beiden Entitäten häufig Übertragung auf Kolonkarzinome, sodass zusammenfassend auch von kolorektalen Karzinomen geschrieben wird. Auf makroskopischer Ebene ist eine sequenzielle Entstehung von Karzinomen als sogenannte Adenom-Karzinom-Sequenz etabliert. In dieser Sequenz entwickeln sich Karzinome aus Adenomen, die zuvor als Polypen der Darmschleimhaut einzustufen sind (Muto et al. 1975). Während einer Koloskopie können solche Schleimhautpolypen präventiv entfernt werden, wodurch sich die Erkrankungsrate von kolorektalen Karzinomen sowie die durch kolorektale Karzinome bedingte Mortalität stark reduzieren lässt. Daher werden mittlerweile Koloskopien mit endoskopischer Polypektomie zu diagnostischen als auch therapeutischen Zwecken standardmäßig durchgeführt (Winawer et al. 1993; Zauber et al. 2012). Insbesondere in der Altersgruppe ab dem 50. Lebensjahr kommt es zu einer starken Zunahme der Anzahl an Polypen und an Karzinomen, die sich im Rahmen einer Koloskopie nachweisen lassen. Präventionsstrategien zielen daher vor allem auf diese Alterskohorte ab. Allerdings sind Karzinome sowie Polypen auch schon bei Patienten nachweisbar, die das 50. Lebensjahr noch nicht erreicht haben (Imperiale et al. 2002).

Verschiedene Risikofaktoren wie z. B. Rauchen, Übergewicht und eine ballaststoffarme Ernährung wurden in Zusammenhang mit der Entstehung von kolorektalen Karzinomen gebracht. In einer dänischen prospektiven Kohortenstudie ging eine Reduktion der genannten Risikofaktoren mit einer Reduktion der Krankheitshäufigkeit einher (Kirkegaard 
et al. 2010). Besonders gefährdet im Verlauf ihres Lebens an einem kolorektalen Karzinom zu erkranken, sind Patienten, welche an einer chronisch entzündlichen Darmerkrankung leiden (Eaden et al. 2001; Jess et al. 2005). Darüber hinaus existieren Personengruppen mit familiär gesteigertem Risiko. Hierbei handelt es sich um Anlageträger von verschiedenen Genmutationen, welche mit einem erhöhten Erkrankungsrisiko einhergehen (Jasperson et al. 2010).

Anhand von Größe sowie Infiltrationsgrad des Primärtumors, dem Befall von Lymphknoten und dem Vorliegen von Fernmetastasen wird ein Erkrankungsstadium der TNMKlassifikation festgelegt (Brierley et al. 2017). Stark abhängig vom Ausbreitungsstadium der Erkrankung ist die Prognose des kolorektalen Karzinoms, ebenso bieten sich unterschiedliche therapeutische Möglichkeiten. Eine chirurgische Resektion des Tumors steht meist im Mittelpunkt der Therapie. Die als totale mesorektale Exzision bzw. komplette mesokolische Exzision bezeichnete Operationstechnik orientiert sich an den während der Embryonalentwicklung angelegten trennenden Strukturen der viszeralen sowie parietalen Peritonealblätter. Zu den Grundsätzen einer onkologischen Resektion gehört, neben der kompletten Exzision des Tumors, die zentrale Ligatur versorgender Gefäße und die Entfernung drainierenden Lymphgefäße und -knoten (Heald 1988; Hohenberger et al. 2009). Weiterhin stehen verschiedene Kombinationstherapien aus unterschiedlichen Chemotherapeutika und auch monoklonalen Antikörpern zur Verfügung, wobei Kombinationen aus 5-Fluorouracil und Oxaliplatin oder Irinotecan die am häufigsten angewandten primären Therapiekonzepte darstellen. Etwa die Hälfte der Patienten erhalten dabei zusätzlich eine Therapie mit einem monoklonalen Antikörper. (Abrams et al. 2014).

Diese vergleichsweise neue Therapieoption mit Antikörpern stellt eine Form der gerichteten, molekularen Therapie dar. Der für die Therapie des metastasierten kolorektalen Karzinoms am häufigsten verwendete Antikörpers ist Bevacizumab, wobei es sich um einen Inhibitor des vascular endothelial growth factors handelt (Hurwitz et al. 2004; Abrams et al. 2014). Darüber hinaus besteht durch selektive epidermal growth factor receptor (EGFR) Antikörper eine zweite Möglichkeit der gerichteten, molekularen Therapie (Cunningham et al. 2004). Der therapeutische Effekt dieser Behandlung ist abhängig vom Mutationsstatus von kirstin rat sarcoma viral oncogene homolog (KRAS). Dabei handelt es sich um einen intrazellulären Mediator des EGFR-Signalwegs. Aktivierende Mutationen von Mediatoren des mitogen-activated protein kinase (MAPK) -Signalwegs oder Phosphoinositid-3-Kinase (PI3K) -Signalwegs vermindern die therapeutische Wirkung von EGFR-Inhibitoren (Lièvre et al. 2006).

Für die Entstehung von kolorektalen Karzinomen gilt die Akkumulation einiger somatischer Mutationen in entscheidenden Genen über den Zeitraum von mehreren Jahren als notwendig. Weitere Mutationen, die für die Krebsentstehung von geringerer Bedeutung sind, kommen ebenfalls hinzu (Vogelstein et al. 1988; Tomasetti et al. 2015). Hieraus resultierend wurde ein genetisches Modell der Entstehung von kolorektalen Karzinomen entwickelt, welches durch das Auftreten von Mutationen in einigen typischen Genen wie 
adenomatous poliposis coli (APC), KRAS und TP53 geprägt ist (Fearon 2011). Insbesondere Mutationen von $A P C$ scheinen eine der frühsten Veränderungen darzustellen, die als Voraussetzung für die Entstehung von kolorektalen Karzinomen gelten (Sottoriva et al. 2015; Yang et al. 2019). APC ist entscheidend bei der Regulierung des WNT/ $\beta$-CateninSignalwegs (Clevers und Nusse 2012). Zu diesen entscheidenden Mutationen, welche als Voraussetzung für die Karzinomentstehung und -progression angenommen werden können, kommen weitere Mutationen in verschiedenen Signalwegen dazu (Feng et al. 2019).

\subsection{Der Tumorsuppressor TP53}

Der Tumorsuppressor TP53 ist in malignen Tumoren eines der am häufigsten mutierten Gene, welches in ca. $60 \%$ der kolorektalen Malignome mutiert vorliegt (Giannakis et al. 2016). Der Verlust des Tumorsuppressors TP53 in kolorektalen Karzinomen markiert den Übergang vom Adenom zum invasiven Karzinom (Baker et al. 1990). Keimbahnmutationen von TP53 sind ursächlich für das Li-Fraumeni-Syndrom. Hierbei handelt es sich um ein hereditäres Tumorsyndrom. Betroffene entwickeln oft schon in einem jungen Alter multiple solide Tumore wie z. B. Mammakarzinome oder Sarkome (Malkin et al. 1990). Auch im Mausmodel führt der genetische knock-out zu einem Phänotyp, der sich durch die spontane Entwicklung von Krebserkrankungen insbesondere malignen Lymphomen auszeichnet, somit jedoch phänotypisch verschieden vom Li-Fraumeni-Syndrom ist (Donehower et al. 1992).

TP53 codiert für den Transkriptionsfaktor p53 (Abbildung 1). p53 gliedert sich in Nterminale Transaktivierungsdomänen, auf welche eine Prolin-reiche Region folgt. Zentral befindet sich die DNA-bindende Domäne. C-terminal sind eine Oligomerisierungs- sowie eine C-terminale Domäne nachweisbar (Kaiser und Attardi 2018).

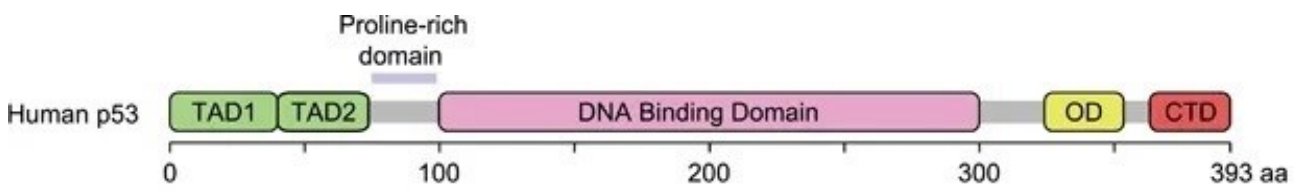

Abbildung 1: Struktur von p53. Modifiziert nach Sullivan et al. (2018). Die Verwendung erfolgt unter der Creative Commons Attribution-Non-Commercial-NoDerivs 4.0 International Licence.

Die transkriptionelle Aktivität von p53 ist streng reguliert (Abbildung 3). Entscheidend an der Regulierung beteiligt ist mouse double minute 2 (MDM2), welches p53 bindet und in seiner Aktivität beschränkt (Momand et al. 1992). MDM2 dient dabei als E3-Ubiquitin-Ligase, welche die Ubiquitinierung von p53 vermittelt und somit für den Abbau durch das Proteasom markiert (Fang et al. 2000). Zusätzlich scheint MDM2 den nukleären Export von 
p53 in das Zytoplasma zu fördern, was zum Abbau von p53 beiträgt (Boyd et al. 2000). p53 selbst reguliert die Expression von MDM2 auf transkriptioneller Ebene positiv, sodass vermehrte p53-Aktivität mit einer Zunahme der MDM2-Expression im Sinne einer negativen Rückkopplungsschleife einhergeht (Wu et al. 1993).

$\mathrm{Zu}$ den Funktionen von p53 gehört die Induktion von Zellzyklusarrest, Seneszenz und Apoptose. Verschiedene zelluläre Stressreize wie DNA-Schädigung, Hypoxie, Nährstoffmangel können eine p53-Aktivierung herbeiführen (Kaiser und Attardi 2018). Daraufhin akkumuliert p53 rasch, was zunächst mit Zellzyklusarrest in der G1-Phase sowie einem Stopp der replikativen DNA-Synthese einhergeht (Kastan et al. 1991). Hieran zentral beteiligt ist das p53-regulierte Gen $C D K N 1 A$, welches für p21 kodiert, einem Inhibitor von Cyclinabhängigen Kinasen (CDK). Nach p53-Aktivierung induziert p53 die Expression von p21 (el-Deiry et al. 1993). Durch Bindung und Inhibition von CDK-Komplexen kann p21 die Phosphorylierung des Retinoblastoma Proteins $(\mathrm{Rb})$ verhindern und induziert somit einen Zellzyklusarrest (Abbildung 2) (Harper et al. 1993).

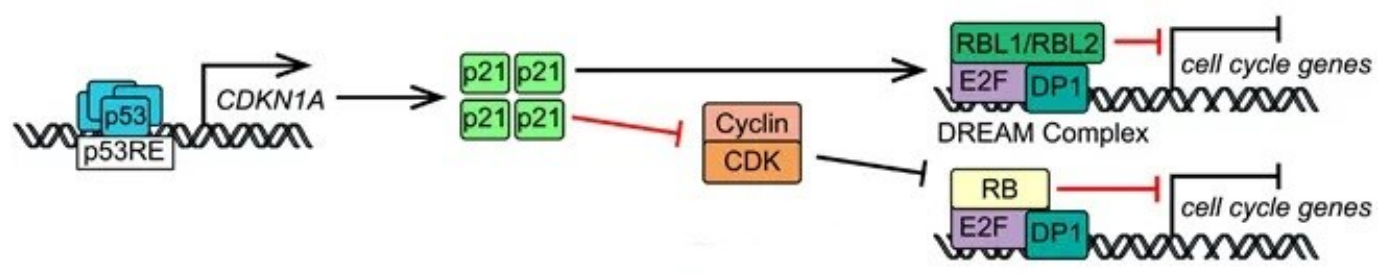

Abbildung 2: p21 inhibiert CDKs und vermittelt einen p53-abhängigen Zellzyklusarrest. Modifiziert nach Sullivan et al. (2018). Die Verwendung erfolgt unter der Creative Commons Attribution-NonCommercial-NoDerivs 4.0 International Licence.

CDKs stellen eine diverse Familie von Kinasen dar, welche in der Regulation des Zellzyklus sowie der Transkription beteiligt sind. Die Aktivität von CDKs hängt von sogenannte Cyclinen ab; Proteine, deren Konzentrationen während des Zellzyklus charakteristisch oszillieren (Malumbres 2014). Verschiedene Inhibitoren stehen für die Beeinflussung von CDKs zu Verfügung. Der Inhibitor PD0332991 hemmt selektiv CDK4/6 und findet unter dem Namen Palbociclib bereits bei der Therapie von Brustkrebs klinische Anwendung (Finn et al. 2009). Auch der Inhibitor LEE001 hemmt CDK4/ 6 selektiv (Tripathy et al. 2017). Der Inhibitor RO3306 hemmt selektiv CDK1, für die Verwendung in höheren Konzentrationen ist jedoch auch die Inhibition anderer CDKs angegeben (Vassilev 2006).

Für die Aktivierung von p53 ist es notwendig die negative Rückkopplungsschleife zwischen p53 und MDM2 zu unterbrechen. Dies gelingt z. B. durch MDM2-Inhibition, was p53 aus dem p53-MDM2-Komplex freisetzt und aktiviert. Eine Aktivierung von p53 kann auch pharmakologisch durch den Inhibitor Nutlin-3a erreicht werden, der selbst MDM2 bindet 
(Abbildung 3A) (Vassilev et al. 2004). Ein anderer spezifischer MDM2-Inhibitor ist RG7112 (Vu et al. 2013).

Im Kontext von zellulärem Stress wird p53 durch posttranslationale Modifizierung von p53 und MDM2 zusätzlich aktiviert (Abbildung 3B). Verschiedene Proteinkinasen sind identifiziert worden, die p53 und MDM2 phosphorylieren und somit zur p53-Aktivierung beitragen. Ein sehr starke p53-Aktivierung erfolgt durch DNA-Schädigung. Hierbei werden eine Vielzahl von Signalwegen aktiviert, die für die DNA-Reparatur notwendig sind (Shieh et al. 1997; Khosravi et al. 1999; Tibbetts et al. 1999). Nach p53-Aktivierung durch DNASchädigung werden Signalwege zur DNA-Reparatur angestoßen. Gelingt eine Reparatur der DNA-Schäden nicht, werden p53-abhängig Apoptose-auslösende Gene wie z. B. PUMA, NOXA, BAX induziert (Kaiser und Attardi 2018).

A

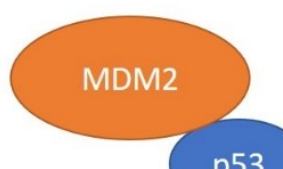

p53
B

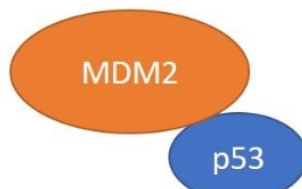

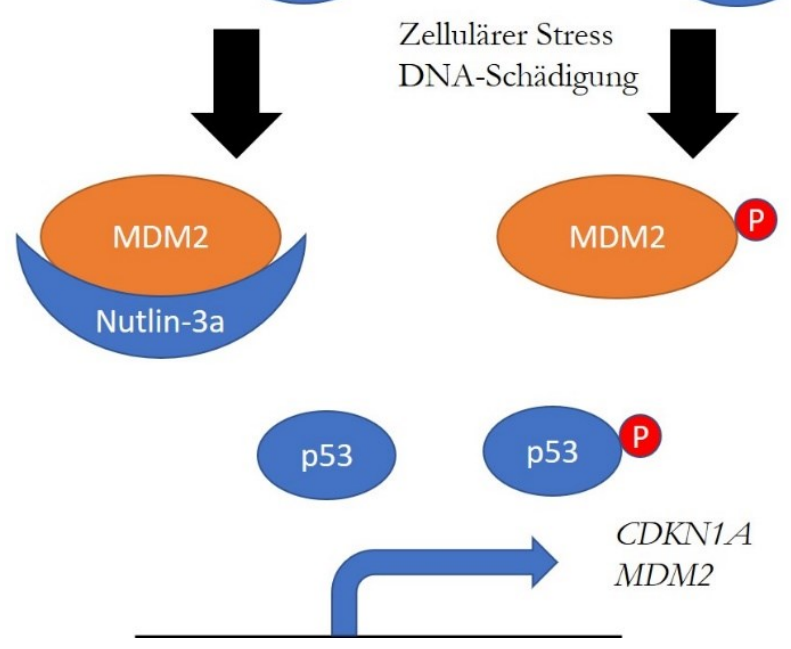

Abbildung 3: Die Freisetzung von p53 aus dem Komplex mit MDM2 ermöglicht eine p53-Aktivierung. Grafik erstellt nach Vassilev et al. (2004) und Kaiser und Attardi (2018). (A) Der Inhibitor Nutlin-3a bewirkt die Freisetzung von p53 aus dem Komplex mit MDM2. (B) Verschiedene Reize können eine Phosphorylierung von MDM2 und p53 bewirken, was zur p53-Aktivierung führt. Die transkriptionelle Regulierung von MDM2 durch p53 stellt eine negative Rückkopplungsschleife dar.

Zahlreiche Gene werden durch p53 reguliert und tragen zur vielfältigen Wirkung von p53 nach Aktivierung bei (Abbildung 4). Durch verschiedene Mechanismen, auf welche hier nur verwiesen werden soll, wie z. B. die Regulation von Ferroptose, die Förderung zellulärer Differenzierung und die Inhibition von Glykolyse als Antwort auf chronischen onkogenen Stress, wirkt p53 ebenfalls als Tumorsuppressor (Kaiser und Attardi 2018). In Tumoren, welche wildtypisches TP53 aufweisen, ist die vermehrte Expression von p53-regulierten Genen wie RPS27L, CDKN1A, und ZMAT3 nachweisbar (Parikh et al. 2014). 

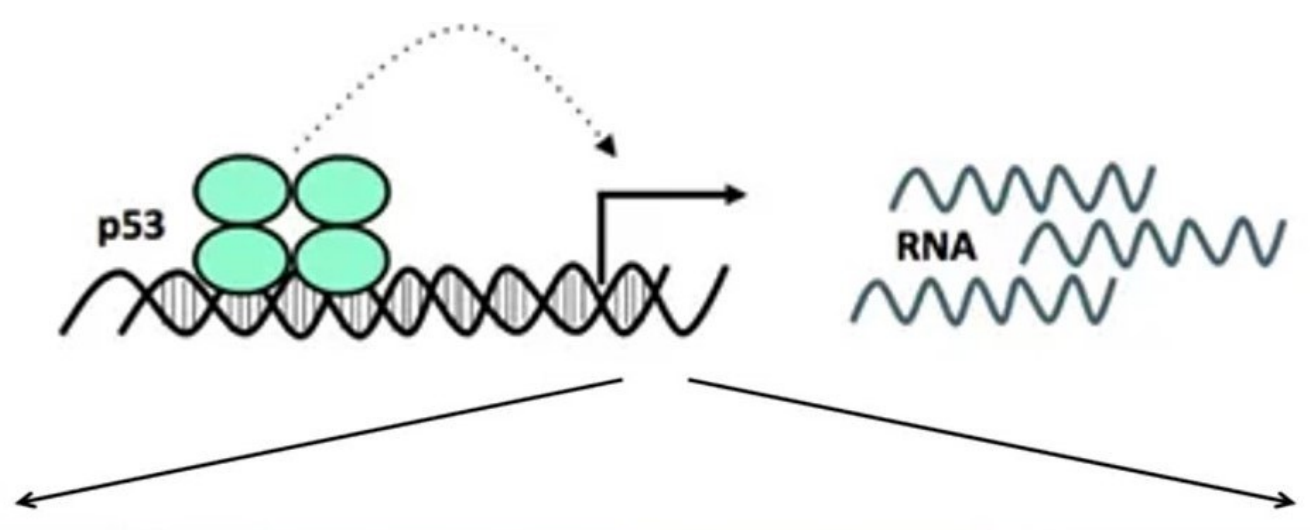

\begin{tabular}{l|l|l|l}
\hline Apoptosis & Cell Cycle Arrest & Senescence & DNA Repair \\
\hline Apaf1 & $14-3-3$ & Cdkn1a & Ddb2 \\
Bax & Btg2 & Pai1 & Recc5 \\
Fas & Ccng1 & Pml & Fancc \\
Mir-34 & Cdkn1a & & Gadd45a \\
Noxa & Gadd45a & & Ku86 \\
Traf4 & mir-34a & & Mgmt \\
Perp & mir-34b/c & & Mlh1 \\
Pidd & Prl3 & & Msh2 \\
Pig3 & Ptprv & Polh \\
Puma & Reprimo & & Polk \\
Siva & Zmat3 & & Rrm2b \\
Tnfrsf10d & & & Xpc
\end{tabular}

Abbildung 4: Übersicht ausgewählter, p53-regulierter Gene. p53 reguliert ein komplexes Gennetzwerk, welches an einer Vielzahl von zellulären Funktionen beteiligt ist. Modifiziert nach (Kaiser und Attardi 2018). Die Verwendung erfolgt mit freundlicher Genehmigung des Verlages Springer Nature. Lizenznummer 4780141507808.

Im Mausmodell induziert die p53-Aktivierung in unmittelbarer zeitlicher Folge auf DNASchädigung vor allem Apoptose und Zelluntergang (Christophorou et al. 2006). Lymphome entstehen in einem ähnlichen Model erst nach p53-Verlust mit einer altersabhängigen Latenz, sodass das langfristige Vorhandensein sowie eine andauernde basale Aktivität von wildtypischem p53 für die Tumorsuppression notwendig zu sein scheinen (Hinkal et al. 2009).

Im Mausmodell des kolorektalen Karzinoms ist die initiale p53-Aktivierung für DNAReparatur und Apoptose notwendig und der knock-out von p53 korreliert mit einer erhöhten Tumorinzidenz nach Karzinogenexposition (Schwitalla et al. 2013). Zusätzlich kommt es in der späteren Tumorentwicklung beim Fehlen von p53 indirekt zur vermehrten Aktivierung von Signalwegen, die Entzündungsprozesse vermitteln, einem vermehrten infiltrativen Wachstum der Tumore und dem Auftreten von Lymphknotenmetastasen (Schwitalla et al. 2013). 


\subsection{Mutationen von TP53}

Während Mutationen von TP53 in fast allen Krebsentitäten nachweisbar sind, unterscheiden sich die verschiedenen Entitäten hinsichtlich der Häufigkeit und Art der Mutationen. Verändernde Mutationen betreffen häufig die DNA-bindende Domäne und sind ein Merkmal fortgeschrittener, aggressiver Tumore (Olivier et al. 2010). Hinsichtlich ihres Genotyps lassen sich neben Tumoren mit wildtypischem TP53, deletierende Mutationen, welche einen loss-of-function erzeugen, und sogenannte Missense-Mutationen unterscheiden. Bei Missense-Mutationen handelt es sich um Punktmutationen, bei denen es nicht zu einem Abbruch der Translation kommt, aber durch konformationelle Änderung ein aberrantes Protein entsteht (Parikh et al. 2014).

Für einige Missense-Mutationen ließ sich in vivo ein gain-of-function, also der Zugewinn onkogener Wirkung durch Mutation, demonstrieren. Das Vorhandensein bestimmter Mutationen scheint gegenüber reinen Deletionen von TP53 die Tumorprogression zu fördern (Olive et al. 2004). Besonders die R248Q-Mutation zeichnet sich durch einen ausgeprägten gain-of-function aus, der im Mausmodel durch das verfrühte Auftreten von Malignomen und einem verkürzten Überleben auffällt (Hanel et al. 2013). Notwendig für diesen Effekt ist eine erhöhte Konzentration von p53 durch Proteinstabilisierung des mutierten p53-Proteins. Hierfür verantwortlich ist eine vermehrte Aktivität und Bindung des Chaperones HSP90 an das aberrante p53-Protein (Alexandrova et al. 2015). Im Mausmodel des kolorektalen Karzinoms führt die Stabilisierung von mutiertem p53 zu größeren und invasiven Tumoren; dabei kann durch pharmakologische Inhibition von HSP90 die Stabilisierung von mutiertem p53 verringert werden, was mit dem Verlust der onkogenen Wirkung von mutiertem p53 einhergeht (Schulz-Heddergott et al. 2018).

\subsection{Das stressinduzierte Chaperone-System und der heat- shock factor 1}

Eine Reihe von Proteinen, welche als heat-shock proteins (HSP) bezeichnet werden, fungieren als molekulare Chaperone. HSPs tragen zur korrekten Proteinfaltung bei und unterbinden die Fehlfaltung von Proteinen; ist eine korrekte Proteinfaltung nicht möglich tragen Chaperone zum Proteinabbau bei (Whitesell und Lindquist 2005). In Zellen existiert eine basale, konstitutive Expression von HSPs. Daneben gibt es auch eine durch zellulären Stress induzierbare Expression von HSPs, welche vom heat-shock factor 1 (HSF1) abhängig ist (McMillan et al. 1998). Für eine korrekte Proteinfaltung ist in normalen Zellen ein Komplex aus verschiedenen HSPs nötig, der in seiner Funktion maßgeblich von HSP90 bestimmt wird (Smith et al. 1995).

In malignen Zellen ist die Aktivität und Funktion von HSPs verändert. Dabei geht der Komplex aus HSP90 und anderen Co-Chaperonen in einen hoch aktiven Zustand über, der zur Stabilisierung multipler Onkoproteine wie HER-2/ErbB2, Akt oder Bcr-Abl beiträgt 
(Kamal et al. 2003). Hierdurch verliert HSP90 seine eigentliche Funktion als Chaperone und stabilisiert mutierte, fehlgefaltete Onkoproteine, die für den malignen Phänotyp entarteter Zellen notwendig sind (Abbildung 5).

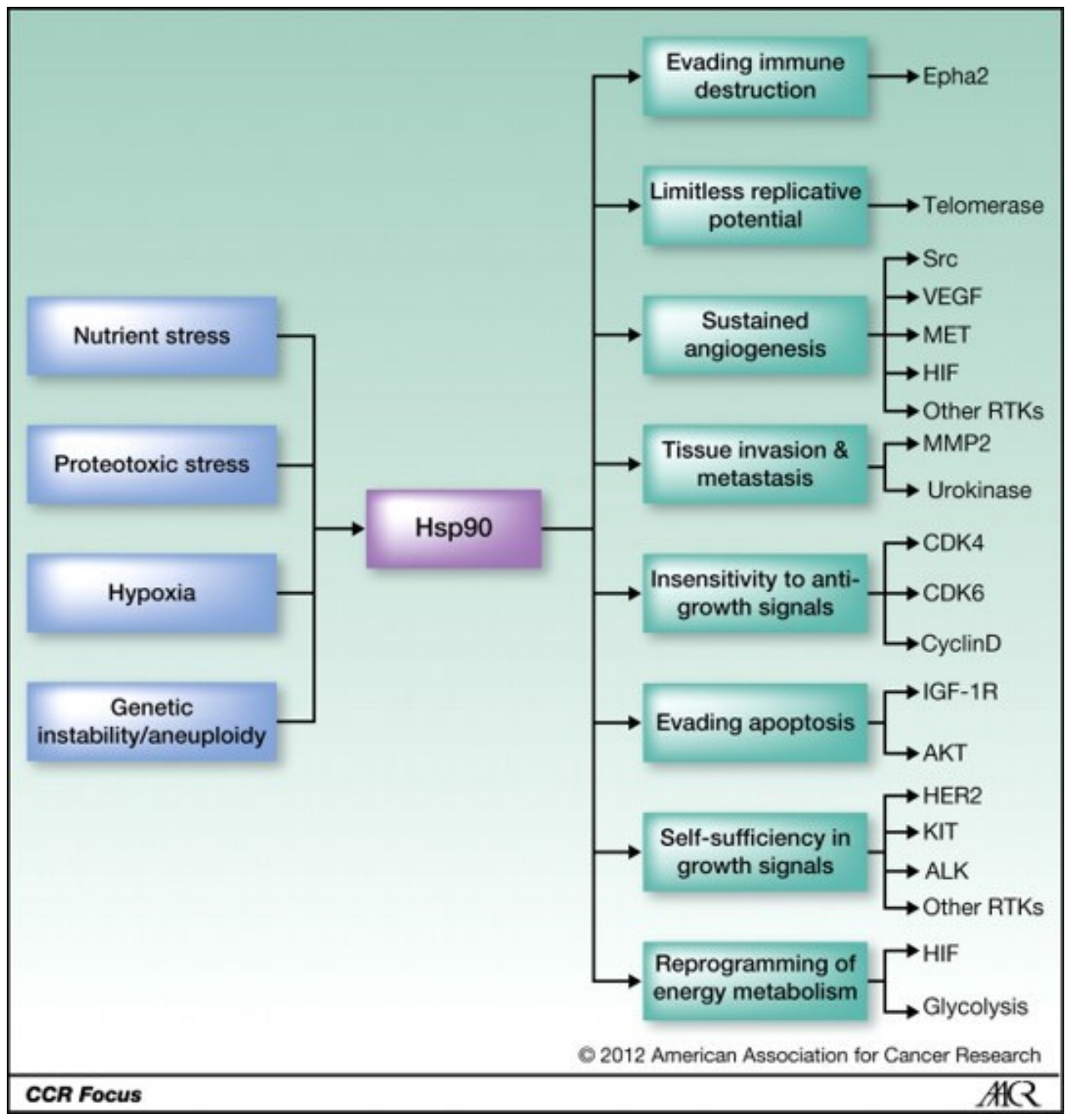

Abbildung 5: HSP90 im stressinduzierten Chaperone-Netzwerk. HSP90 wird durch zellulären Stress induziert und stabilisiert eine Reihe von Onkoproteinen (Neckers und Workman 2012). Die Verwendung erfolgt mit freundlicher Genehmigung der American Association for Cancer Research. Lizenznummer 4780201199623.

Neben HSP90 existieren weitere HSPs wie HSP110, HSP70 und HSP27, die als molekulare Chaperone fungieren und in Krebszellen häufig überexprimiert sind (Calderwood und Gong 2016).

Der Transkriptionsfaktor HSF1 reguliert die zelluläre Stressantwort auf Reize wie Hitze, Schwermetalle oder Infektionen. Die zelluläre Stressantwort umfasst eine veränderte 
Expression verschiedener Gene (Ritossa 1962). Während ein großer Teil der HSF1regulierten Gene zu den Chaperonen zu zählen ist, sind unter den regulierten Genen auch solche, die andere biologische Funktionen erfüllen. HSF1 spielt also nicht nur bei der Bewältigung von proteotoxischem Stress eine wichtige Rolle, sondern reguliert auch Gene, welche in unterschiedlichen zellulären Prozessen involviert sind (Hahn et al. 2004). Während in Modellorganismen wie Saccaromyces cerevesiae oder Drosophila melanogaster nur eine HSF-Isoform vorkommt, besitzen Säugetierzellen mindestens vier HSF-Isoformen. HSF1 gilt dabei als die funktionell bedeutsamste Isoform. Die stressinduzierte Expression von HSPs ist stark reduziert und die Tumorentwicklung ist stark abhängig von HSF1 (McMillan et al. 1998; Dai et al. 2007).

HSF1 gliedert sich in mehrere Proteindomänen. N-terminal befindet sich eine DNAbindende Domäne neben einer Oligomerisierungsdomäne. Weiterhin sind eine zentrale, regulatorische Domäne sowie eine Transaktivierungsdomäne vorhanden, die sich C-terminal befindet (Abbildung 6). Reize, die das vermehrte Auftreten von fehlgefalteten Proteinen hervorrufen, führen zur Aktivierung von HSF1. Mehrere Mechanismen sind an der Regulierung von HSF1 beteiligt, die zu einem differenzierten Aktivierungsmuster beitragen (Anckar und Sistonen 2011).

a

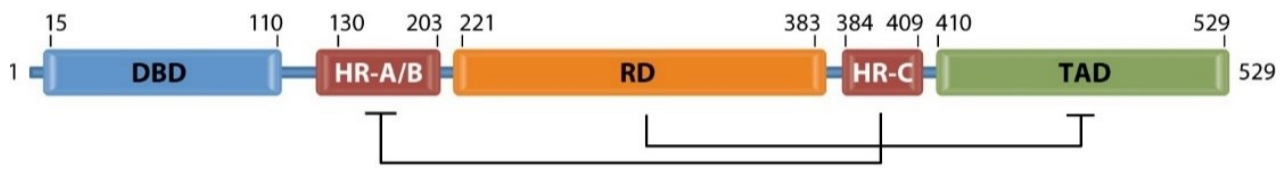

Abbildung 6: Proteinstruktur von HSF1. Aus Anckar und Sistone (2011). Die Verwendung erfolgt mit freundlicher Genehmigung des Verlages Annual Reviews. Lizenznummer 1020857-1.

HSF1 liegt in inaktivierter Form als Monomer vor und ist diffus im gesamten Zytoplasma verteilt. Durch Stressreize kommt es zur HSF1-Aktivierung, die mit Trimerisierung und rascher, nukleären Akkumulation von HSF1 einhergeht (Sarge et al. 1993). HSF1 akkumuliert dabei in distinkten, subnukleären Strukturen, die mit einer Transition von HSF1 zu Orten der aktivierten Transkription in Zusammenhang gebracht werden (Jolly et al. 1997). HSF1Trimere binden sogenannte beat-shock elements (HSE) in der Promotorregion regulierter Zielgene (Abbildung 7). HSEs bestehen aus repetitiven nGAAn-Sequenzen; die dabei induzierte Transkriptionsaktivität hängt davon ab, ob ein HSF1-Homotrimer oder z. B. ein Heterotrimer aus HSF1 und dem heat-shock factor 2 bindet (Sandqvist et al. 2009). 
b

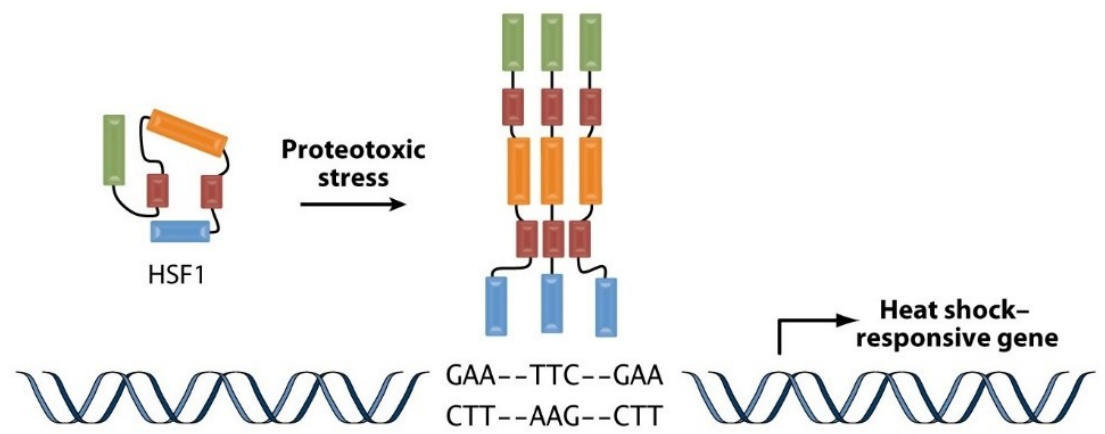

Abbildung 7: HSF1-Trimerisierung und Bindung an HSEs. HSF1-Aktivierung geht mit Trimerisierung und Bindung an HSEs in der Promotorregion regulierter Gene einher (Anckar und Sistonen 2011). Die Verwendung erfolgt mit freundlicher Genehmigung des Verlages Annual Reviews. Lizenznummer 1020857-1.

Trimerisierung von HSF1 wird durch HSP90 beeinflusst, dabei werden HSF1-Monomore durch Komplexbildung mit HSP90 in einem inaktiven, monomeren Zustand gehalten. Durch den vermehrten Anfall von fehlgefalteten Proteinen kommt es zur Freisetzung von HSF1 aus dem Komplex, wobei HSP90 durch die anfallenden, fehlgefalteten Proteine sequestriert wird. Dies wird auch als replacement-model bezeichnet. Dieser Mechanismus trägt durch das alleinige vermehrte Auftreten von fehlgefalteten Proteinen zu einer Trimerisierung sowie Bindung von DNA durch eine partielle HSF1-Aktivierung bei (Zou et al. 1998).

Eine erhöhte Aktivität von HSF1 wird zusätzlich durch verschiedene posttranslationale Modifizierungen reguliert, wobei insbesondere der Einfluss von Phosphorylierungen beschrieben wurde (Anckar und Sistonen 2011). Zellulärer Stress führt dabei zur Phosphorylierung an verschiedenen Positionen hauptsächlich im Bereich der regulatorischen Domäne (Abbildung 8). Während verschiedene Phosphorylierungsstellen identifiziert werden konnten, scheint lediglich die Phosphorylierung des Serinrestes an Position 326 signifikanten Einfluss auf die Aktivität von HSF1 zu haben und zur Aktivitätssteigerung beizutragen (Guettouche et al. 2005). Die konstitutive Phosphorylierung der Serinreste an der Position 303 bzw. an Position 307 lässt HSF1 hingegen in einem inaktiven Zustand verbleiben (Kline und Morimoto 1997). 


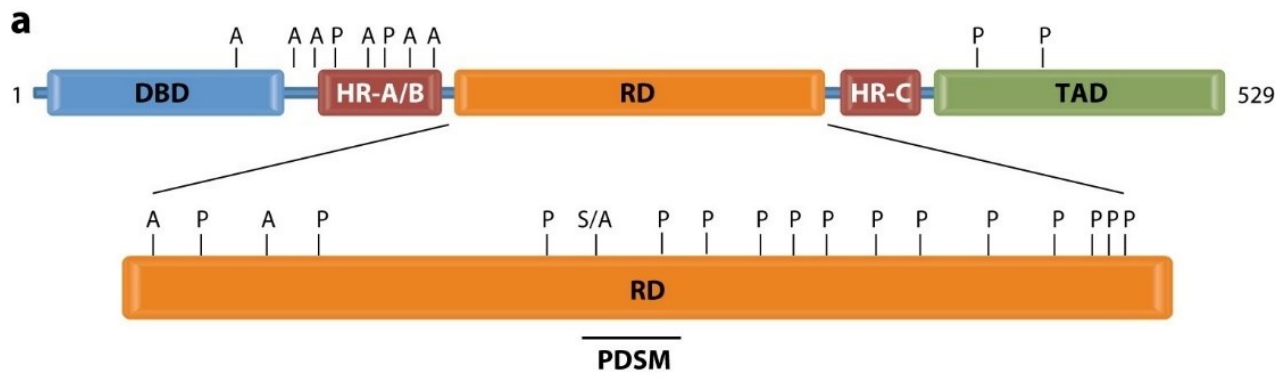

Abbildung 8: Modifizierungen beeinflussen die Aktivität von HSF1. Zahlreiche posttranslationale Modifizierungen sind beschrieben, wobei insbesondere der Einfluss von Phosphorylierungen im Bereich der regulatorischen Domäne entscheidend die HSF1-Aktivität beeinflusst (Anckar und Sistonen 2011). Die Verwendung erfolgt mit freundlicher Genehmigung des Verlages Annual Reviews. Lizenznummer 1020857-1.

Bisher konnte nur für einen kleinen Teil der Phosphorylierungen eine vermittelnde Kinase identifiziert werden. Für die Phosphorylierung von Ser326 haben sich bisher experimentell mehrere vermittelnde Kinasen identifizieren lassen. Die HSF1-Aktivität nach Hitzeschockbehandlung und pHSF1 können in vitro durch knock-down des mammalian target of rapamycin (mTOR) aus dem PI3K-Signalweg inhibiert werden (Chou et al. 2012). Der PI3K-Signalweg kann in vitro spezifisch durch Ly294002 gehemmt werden (Gharbi et al. 2007).

Zusätzlich wurde die Regulierung durch die beiden Kinase mitogen-activated protein kinase kinase (MEK) und extracellular signal related kinase (ERK) beschrieben, die beide zum MAPKSignalweg zählen (Tang et al. 2015). MEK-Inhibition verringert die HSF1-Aktivität, während eine ERK-Inhibtion den gegenteiligen Effekt erzielt. Vermittelnd scheinen dabei die Phosphorylierungen von Ser326 und Ser307 zu sein. MEK bindet HSF1 direkt, phosphoryliert Ser326 und unterdrückt dadurch die Phosphorylierung von Ser307. ERK wirkt gegenteilig. Da ERK gleichzeitig in seiner Aktivität durch MEK reguliert wird, scheint dieser Signalweg zu einer differenzierten HSF1-Aktivierung beizutragen. Für eine MEKInhibition konnte zusätzlich eine krebstherapeutische Wirkung nachgewiesen werden, die mit erhöhter intrazellulärer Amyloidablagerung im Mausmodell als Zeichen einer verminderten Bewältigung von proteotoxischem Stress einhergeht. Der therapeutische Effekt ist dabei synergistisch zu Bortezomib (Tang et al. 2015).

\subsection{HSF1 in der Rolle eines Non-Onkogens}

Krebszellen sind gegenüber normalen Zellen in einer Reihe von Eigenschaften verändert und zeigen ein aberrantes biologisches Verhalten. Eine Reihe von prinzipiellen Kennzeichen von malignen Zellen wurden von Hanahan und Weinberg (2011) umfassend beschrieben. Die mit der malignen Transformation in Zusammenhang stehenden Veränderungen verursachen zellulären Stress, der Krebszellen vor besondere Herausforderungen stellt 
(Amend und Pienta 2015). Es kommt dabei unter anderem zu veränderter, disproportionaler Proteinbiosynthese, was als proteotoxischer Stress bezeichnet wird und vermehrter Zellproliferation durch deregulierte Zellsignalwege. Zusätzlich liegt in Krebszellen häufig Hypoxie und Nährstoffmangel vor. Dies versuchen Krebszellen durch eine erhöhte Expression von HSPs zu kompensieren (Whitesell und Lindquist 2005; Oromendia et al. 2012).

Die Aktivität von HSF1 in Krebszellen ist stark erhöht, da Krebszellen unter Stress stehen, der eine starke HSF1-Aktivierung und Chaperon-Expression herbeiführt. Die vermehrte nukleäre Akkumulation von HSF1 konnte als prognostisch relevanter Faktor für Brustkrebspatientinnen identifiziert werden und scheint auch für andere Tumore mit dem Fortschreiten der Erkrankung, dem Auftreten von Metastasen und einer insgesamt schlechteren Prognose assoziiert zu sein (Santagata et al. 2011; Scott et al. 2011; Fang et al. 2012). Dabei kommt es sowohl zu einer erhöhten quantitativen Expression von HSF1 als auch zu einer erhöhten Aktivität, gekennzeichnet durch eine Verstärkung von pHSF1 und vermehrter nukleärer HSF1-Akkumulation. Dies induziert jedoch nicht nur die vermehrte Expression von Chaperonen, sondern auch die Expression von Genen, die spezifisch in Tumorzellen durch HSF1 reguliert werden und an einer Reihe von biologischen Funktionen wie Zellmigration oder Zellzyklusregulation beteiligt sind (Mendillo et al. 2012).

Die Aktivierung von HSF1 wird in Brustkrebszellen, welche den buman epidermal growth factor receptor 2 (HER2) aufweisen, durch Verstärkung von pHSF1 über die HER2-Akt-mTOR-Achse gesteigert. Dies geht mit vermehrter Expression von Chaperonen einher (Schulz et al. 2014). HER2 wird wiederum durch HSP90 stabilisiert, was eine positive Rückkopplungsschleife darstellt. Zusammenfassend tragen mehrere proliferativ-wirksame Signalwege zur Modifizierung und Aktivierung von HSF1 bei (Anckar und Sistonen 2011).

Die funktionelle Relevanz von HSF1 wurde in verschiedenen Modellsystemen überprüft. Die Wirkung von HSF1 wurde dabei von Solimini (2007) zusammenfassend als „NonOncogen Addiction“ bezeichnet. Dies soll ausdrücken, dass HSF1 nicht die Wirkung eines klassischen Onkogens besitzt und z. B. durch Mutation oder Amplifikation eine maligne Transformation hervorrufen kann. Nichtsdestotrotz ist HSF1 für Krebszellen in seiner Funktion unerlässlich und für eine maligne Transformation durch andere Onkogene unbedingt nötig (Solimini et al. 2007).

Dai (2007) zeigte wie HSF1 für die Entstehung von toxisch induzierten Hauttumoren im Maustiermodell nötig ist. HSF1-defiziente Mäuse entwickeln weniger Hauttumore und überleben länger als wildtypische Mäuse. Auch überleben Mäuse mit einer knock-in Variante des mutierten p53, die ansonsten spontan verschiedene Tumore entwickeln und an diesen versterben, länger, wenn sie gleichzeitig HSF1-defizient sind. Zusätzlich ist der HSF1-Status für die Transformation durch verschiedene Onkogene wie $\mathrm{R} A S$ entscheidend (Dai et al. 2007). 
Für mutiertes p53 wird ebenfalls ein rekurrenter Effekt auf HSF1 diskutiert. Mutiertes p53, welches durch HSP90 stabilisiert wird, bewirkt eine Aktivierung von HSF1 über pHSF1 via der MAPK- sowie PI3K-Signalwege. Dies führt wiederum zu vermehrter Stabilisierung von mutiertem p53 in Sinne einer positiven Rückkopplungsschleife (Li et al. 2014).

Im p53-knock-out-Mausmodell hat HSF1 eine ambivalente Wirkung. p53-defiziente Mäuse entwickeln normalerweise rasch Lymphome und versterben an diesen. Bei gleichzeitiger HSF1-Defizienz entstehen nur sehr selten primär Lymphome, während es häufiger zu anderen Neoplasien wie Sarkomen kommt, sodass HSF1 in diesem Model auch das Tumorspektrum beeinflusst. Das Überleben beider Gruppen unterscheidet sich allerdings nicht signifikant (Min et al. 2007).

Auch in einem Mausmodel des hepatozellulären Karzinoms zeigt sich die tumorfördernde Wirkung von HSF1. HSF1-defiziente Tiere zeigen verglichen mit Wildtyp-Tieren nur selten Tumore, welche auch nur ein geringes Wachstum aufweisen. Damit zusammenhängend ist die chemisch ausgelöste Entzündungsreaktion in der Leber in HSF1-defizienten Tieren wesentlich geringer und es kommt zu weniger ausgeprägter hepatischer Fetteinlagerung. Nicht nur die Tumorentstehung ist in diesem Model durch HSF1 beeinflusst, sondern auch das Tumormilieu und die -progression fördernden Faktoren (Jin et al. 2011).

Im Zusammenhang mit anderen Tumorsuppressorgenen als p53 ist HSF1 auch beschrieben. Der Verlust des Tumorsuppressorgens Neurofibromatosis Typ 1 führt zu einer Aktivierung von HSF1 durch eine Deregulation des MAPK-Signalwegs. Dies geht mit erhöhtem pHSF1 und vermehrter Expression von HSF1-Zielgenen einher. Im Mausmodell der Neurofibromatose 1 entwickeln sich Tumore erst später und die Mäuse überleben länger, wenn gleichzeitig ein genetischer HSF1 knock-out vorliegt. Das sich entwickelnde Tumorspektrum unterscheidet sich hinsichtlich des HSF1-Status (Dai et al. 2012).

\subsection{Zielsetzung dieser experimentellen Arbeit}

Zielsetzung dieser Arbeit war es den Einfluss von wildtypischem p53 auf den durch Stress aktivierten Transkriptionsfaktor HSF1 zu analysieren. Die Wahl des kolorektalen Karzinoms als Modell ergab sich aus der Schlüsselrolle von p53 für diese Erkrankung sowie aus vorausgehenden Experimenten der Arbeitsgruppe.

Es sollte ermittelt werden, ob wildtypisches p53 einen regulatorischen Einfluss auf die HSF1Aktivität hat und die gesteigerte Expression von Chaperonen in Tumoren inhibiert. Durch die pharmakologische Inhibition verschiedener Signalwege mittels verfügbarer Inhibitoren sollte eine Verbindung zwischen p53 und HSF1 identifiziert werden, konkurrierende Signalwege überprüft und ein mechanistisches Modell der Regulierung entworfen werden. Eine p53-Aktivierung wurde durch Behandlung mit dem MDM2-Inhibitor Nutlin-3a erzeugt. 
Als Maß der HSF1-Aktivität wurden posttranslationale Modifizierungen von HSF1 betrachtet. Der Status von pHSF1 wurde spezifisch in Western Blots überprüft, da für den Einfluss dieser Modifizierung die meisten Hinweise aus der Literatur vorliegen.

Weiterhin wurde die Transkription verschiedener HSF1-regulierter Gene in mehreren Zelllinien untersucht. Die Expression wurde auf Ebene der messenger ribonucleic acid (mRNA) mittels quantitativer real-time Polymerasekettenreaktion (qPCR) ermittelt.

Als Arbeitshypothese wurde ein inhibitorischer Effekt des Tumorsuppressors p53 auf HSF1 angenommen. Falls sich ein inhibitorischer Einfluss von wildtypischem p53 auf HSF1 bestätigt, wäre mit einer verminderten Expression von durch HSF1 regulierten Genen zu rechnen. 


\section{Material und Methoden}

\subsection{Materialien}

\subsubsection{Puffer und Lösungen}

Tabelle 1: Puffer und Lösungen.

\begin{tabular}{|c|c|}
\hline Puffer & Bestandteile \\
\hline 6x Laemmli-Puffer & $\begin{array}{l}350 \text { mM Tris, } \mathrm{pH} 6,8 \\
30 \% \text { Glycerol } \\
10 \% \text { SDS } \\
9,3 \% \text { Dithiotreitol } \\
0,02 \% \text { Bromphenolblau }\end{array}$ \\
\hline Block-Puffer & $\begin{array}{l}5 \% \text { Milchpulver oder BSA in TBS } \\
0,05 \% \text { Tween } 20\end{array}$ \\
\hline CoIP-Puffer & $\begin{array}{l}50 \mathrm{mM} \text { Tris }-\mathrm{HCl}, \mathrm{pH} 7,5 \\
150 \mathrm{mM} \mathrm{NaCl} \\
1 \% \mathrm{NP}-40\end{array}$ \\
\hline Firefly-Puffer & $\begin{array}{l}15 \mathrm{mM} \mathrm{K}_{2} \mathrm{HPO}_{4}, \mathrm{pH} 8,0 \\
25 \mathrm{mM} \mathrm{Glyclyglycin} \\
4 \mathrm{mM} \mathrm{EGTA} \\
15 \mathrm{mM} \mathrm{MgSO}_{4} \\
4 \mathrm{mM} \mathrm{ATP} \\
1,25 \mathrm{mM} \text { Dithiotreitol } \\
0,1 \mathrm{mM} \mathrm{CoA} \\
80 \mu \mathrm{M} \text { Luciferin }\end{array}$ \\
\hline Laufpuffer & $\begin{array}{l}25 \mathrm{mM} \text { Tris }-\mathrm{HCl}, \mathrm{pH} 8,3 \\
192 \mathrm{mM} \text { Glycin } \\
0,1 \% \text { SDS }\end{array}$ \\
\hline phosphat-buffered saline & $\begin{array}{l}150 \mathrm{mM} \mathrm{NaCl}, \mathrm{pH} 7,4 \\
2,7 \mathrm{mM} \mathrm{KCl} \\
1,5 \mathrm{mM} \mathrm{KH}_{2} \mathrm{PO}_{4} \\
4,3 \mathrm{mM} \mathrm{Na}_{2} \mathrm{HPO}_{4} \times 2 \mathrm{H}_{2} \mathrm{O}\end{array}$ \\
\hline qPCR-Puffer & 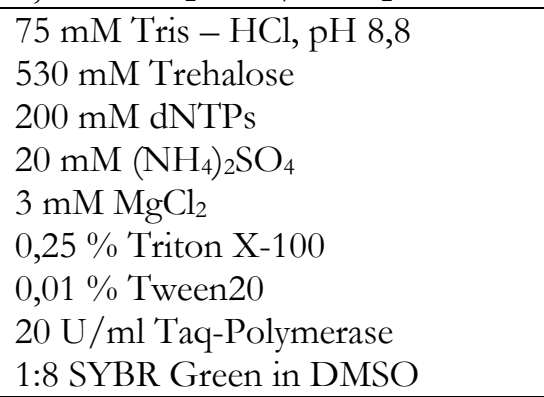 \\
\hline Renilla-Puffer & $\begin{array}{l}\text { 0,22 } \mathrm{M} \mathrm{K}_{2} \mathrm{HPO}_{4}, \mathrm{pH} 5,1 \\
\text { 1,1 } \mathrm{M} \mathrm{NaCl} \\
\text { 2,2 } \mathrm{mM} \mathrm{Na}_{2} \mathrm{EDTA} \\
\text { 1,5 } \mathrm{mM} \mathrm{NaN}_{3} \\
0,5 \mathrm{mM} \mathrm{BSA} \\
\text { 1,5 } \mu \mathrm{M} \text { Coelenterazine }\end{array}$ \\
\hline RIPA-Puffer & $\begin{array}{l}20 \mathrm{mM} \text { Tris }-\mathrm{HCl}, \mathrm{pH} \mathrm{7,5} \\
150 \mathrm{mM} \mathrm{NaCl} \\
10 \mathrm{mM} \text { EDTA } \\
1 \% \text { TritonX-100 }\end{array}$ \\
\hline
\end{tabular}




\begin{tabular}{|l|l|}
\hline Puffer & Bestandteile \\
\hline & $1 \%$ Desoxycholat \\
& $0,1 \%$ SDS \\
\hline TBST & $0,05 \%$ Tween20 in TBS \\
\hline Transferpuffer & $25 \mathrm{mM}$ Tris $-\mathrm{HCl}, \mathrm{pH} 8,3$ \\
& $192 \mathrm{mM}$ Glycin \\
& $5 \mathrm{mM}$ SDS \\
& $15 \%$ Methanol \\
\hline tris-buffered saline & $0,1 \mathrm{M}$ Tris $-\mathrm{HCl}, \mathrm{pH} 7,5$ \\
& $0,15 \mathrm{M} \mathrm{NaCl}$ \\
\hline
\end{tabular}

\subsubsection{Enzyme und Produkte}

Tabelle 2: Enzyme und Produkte für Proteinbiochemie.

\begin{tabular}{|l|l|l|}
\hline Produkt & Hersteller & Katalognummer \\
\hline $\begin{array}{l}\text { Complete } \\
\text { Cocktail }\end{array}$ & Protease Inhibitor & 11836170001 \\
\hline Pierce BCA Protein Assay Kit & Thermo Fisher Scientific & 23225 \\
\hline Sepharose CL4B & Amersham Bioscience & $17-0150-01$ \\
\hline $\begin{array}{l}\text { PageRuler Prestained Protein } \\
\text { Ladder, 10 bis 250 kDa }\end{array}$ & Thermo Fisher Scientific & 26619 \\
\hline $\begin{array}{l}\text { SuperSignal West Femto } \\
\text { Maximum Sensitivity } \\
\text { Substrate }\end{array}$ & Thermo Fisher Scientific & 34095 \\
\hline $\begin{array}{l}\text { Immobilon Western HRP } \\
\text { Substrat }\end{array}$ & Merck Millipore & WBKLS0500 \\
\hline Rotiphorese Gel 30 & Carl Roth & 3029.1 \\
\hline
\end{tabular}

Tabelle 3: Enzyme und Produkte für reverse Transkription \& qPCR.

\begin{tabular}{|l|l|l|}
\hline Produkt & Hersteller & Katalognummer \\
\hline TRIzol®-Reagenz & Thermo Fisher Scientific & 15596026 \\
\hline $\begin{array}{l}\text { M-MuLV Reverse } \\
\text { Transcriptase }\end{array}$ & New England Biolabs & M0253 L \\
\hline $\begin{array}{l}\text { Primer Oligo dT23 VN } \\
\text { Primer (1 mM) }\end{array}$ & Metabion & \\
\hline $\begin{array}{l}\text { Primer Random Nonamers } \\
(1 \mathrm{mM})\end{array}$ & Metabion & B0253 S \\
\hline $\begin{array}{l}\text { M-MuLV Reverse } \\
\text { Transcriptase Reaction Buffer }\end{array}$ & New England Biolabs & S - 7563 \\
\hline SYBR Green in DMSO & Thermo Fisher Scientific & M0307 L \\
\hline RNase Inhibitor & New England Biolabs & $1202,1203,1204,1205$ \\
\hline dNTPs (je 100mM) & Primetech & 1800 \\
\hline Taq Polymerase $(5 \mathrm{U} / \mu \mathrm{l})$ & Primetech & \\
\hline
\end{tabular}

Tabelle 4: Reagenzien und Chemikalien für den dualen Luciferase-Assay.

\begin{tabular}{|l|l|l|}
\hline Produkt & Hersteller & Katalognummer \\
\hline Passive-lysis-buffer (5x) & Promega & E1941 \\
\hline OptiPlate-96 & PerkinElmer & 600529 \\
\hline
\end{tabular}




\subsubsection{Primer für die qPCR}

Primer wurden mittels des Primer-BLAST Programms des National Center for Biotechnology Information entworfen und von Metabion International AG (Planegg/Steinkirchen) bezogen. Lyophilisierte Primer wurden in Wasser gelöst, auf eine Konzentration von $100 \mathrm{pmol} / \mu \mathrm{l}$ eingestellt und dann bei $-20^{\circ} \mathrm{C}$ gelagert.

Tabelle 5: Primer für die qPCR.

\begin{tabular}{|l|l|l|}
\hline $\mathbf{G e n}$ & forward-Primer $\mathbf{5}^{\prime} \mathbf{- 3}^{\prime}$ & $\mathbf{b a c k}^{\prime} \mathbf{a r d}-\mathbf{P r i m e r} \mathbf{5}^{\prime} \mathbf{- 3}^{\mathbf{\prime}}$ \\
\hline CDC6 & TAAAAGCCCTGCCTCTCAGC & TGAGTGAGGGGGACCATTCT \\
\hline HSP90AA & GCCCAGAGTGCTGAATACCC & GTGGAAGGGCTGTT'TCCAGA \\
\hline HSPA1B & TCAAGGGCAAGATCAGCGAG & TGATGGGGTTACACACCTGC \\
\hline HSPB1 & GGAGTGGTCGCAGTGGTTAG & ATGTAGCCATGCTCGTCCTG \\
\hline HSPH1 & ACTGCTTGTTCAAGAGGGCTGTGA & AACATCCACACCCACACACATGCT \\
\hline ITGB3BP & TCCCGAATCTCAGAATGCCTG & TGACAAGTTCCAGTTGTTGGAG \\
\hline RPLP0 & GAT TGGCTACCCAACTGT'TG & CAGGGGCAGCAGCCACAAA \\
\hline
\end{tabular}

\subsubsection{Zellkulturzubehör}

Tabelle 6: Zellkulturzubehör.

\begin{tabular}{|l|l|}
\hline Produkt & Hersteller \\
\hline DMSO & PanReac AppliChem \\
\hline Mikroreaktionsgefäß $(1,5 \mathrm{ml}$ und $2,0 \mathrm{ml})$ & Sarstedt \\
\hline Fetales Kälberserum $(\mathrm{FCS})$ & GIBCO, Thermo Fisher Scientific \\
\hline Falcon Röhrchen $(15 \mathrm{ml}$ und $50 \mathrm{ml})$ & Sarstedt \\
\hline L-Glutamin & GIBCO, Thermo Fisher Scientific \\
\hline Lipofectamine2000 & Thermo Fisher Scientific \\
\hline McCoy's 5 A Medium & GIBCO, Thermo Fisher Scientific \\
\hline Multiwellplatte $(24 \mathrm{er}-)$ & Corning \\
\hline Multiwellplatte $(6 e r-/ 12 \mathrm{er}-/ 24 \mathrm{er}-)$ & Greiner Bio-One \\
\hline Penicillin, Streptomycin & GIBCO, Thermo Fisher Scientific \\
\hline RPMI 1640 Medium & GIBCO, Thermo Fisher Scientific \\
\hline Trypanblau $(0,4 \%)$ & Thermo Fisher Scientific \\
\hline Trypsin-EDTA $0,05 \%$ & GIBCO, Thermo Fisher Scientific \\
\hline Zellkulturschalen Durchmesser $10 \mathrm{~cm} / 15 \mathrm{~cm}$ & Greiner Bio-One \\
\hline Zellschaber $(16 \mathrm{~cm} / 25 \mathrm{~cm})$ & Sarstedt \\
\hline
\end{tabular}

\subsection{5 siRNAs und Plasmide}

Es wurde ausschließlich short interfering ribonucleic acid (siRNA) der Firma Thermo Fisher Scientific verwendet.

Tabelle 7: siRNAs.

\begin{tabular}{|l|l|l|l|}
\hline siRNA-Nummer & Zielgen & Bezeichnet als & Selektivität \\
\hline Scramble 2 (scr2) & Kontroll siRNA & & \\
\hline s415 & CDKN1A & p21 KD \# 1 & silencer select \\
\hline s417 & CDKN1 $A$ & p21 KD \# 2 & silencer select \\
\hline
\end{tabular}




\begin{tabular}{|l|l|l|l|}
\hline siRNA-Nummer & Zielgen & Bezeichnet als & Selektivität \\
\hline s605 & TP53 & p53 KD \#1 & silencer select \\
\hline s607 & TP53 & p53 KD \#2 & silencer select \\
\hline s6951 & HSF1 & HSF1 KD \#1 & silencer select \\
\hline s6952 & HSF1 & HSF1 KD \#2 & silencer select \\
\hline
\end{tabular}

Tabelle 8: Plasmide.

\begin{tabular}{|l|l|l|l|}
\hline Plasmid & Expression & Hersteller & Katalognummer \\
\hline $\begin{array}{l}\text { pRL Renilla Luciferase } \\
\text { Control Reporter } \\
\text { Vector }\end{array}$ & Rluc & Promega & E2241 \\
\hline pcDNA p53 & TP53 & & \\
\hline $\begin{array}{l}\text { pSUPER-p53 for } \\
\text { shp53 }\end{array}$ & shRNA gegen TP53 & OligoEngine & VEC-P53-0001 \\
\hline $\begin{array}{l}\text { Precision LentiORF } \\
\text { positive control }\end{array}$ & Kontrolle & Dharmacon & \\
\hline $\begin{array}{l}\text { Precision LentiORF } \\
\text { HSF1 w/o Stop Codon }\end{array}$ & HSF1 & Dharmacon & OHS5898- \\
\hline $\begin{array}{l}\text { pG14.41 } \\
{[\text { Luc2P/HSE/Hygro }]} \\
\text { Vector }\end{array}$ & luc2P & Promega & E3751 \\
\hline pcDNA3.1 & Kontrolle & & \\
\hline
\end{tabular}

\subsubsection{Chemikalien und Antikörper}

Tabelle 9: Chemikalien für Zellbehandlung.

\begin{tabular}{|l|l|l|}
\hline Chemikalien & Hersteller & Katalognummer \\
\hline Campothecin & Sigma Aldrich & C9911 \\
\hline Doxorubicin & Sigma Aldrich & D1515 \\
\hline LEE011 (Ribociclib) & Selleckchem & S7440 \\
\hline LY294002 & Seleckchem & S7158 \\
\hline MG132 & Calbiochem & 474791 \\
\hline Nutlin-3a & Sigma Aldrich & N6287 \\
\hline PD0332991 (Palbociclib) & Sigma Aldrich & PZ0199 \\
\hline RG7112 & Seleckchem & S7030 \\
\hline RO3306 & Sigma Aldrich & SML0569 \\
\hline
\end{tabular}

Tabelle 10: Antikörper.

\begin{tabular}{|l|l|l|l|l|}
\hline Zielprotein & Wirtstier & Klonalität & Hersteller & Katalognummer \\
\hline Aktin & Maus & monoklonal & abcam & ab6276 \\
\hline CDK4 & Kaninchen & monoklonal & abcam & ab68266 \\
\hline HA-Tag & Kaninchen & monoklonal & Cell Signaling & 3724 \\
\hline HSC70 & Maus & monoklonal & Santa Cruz & sc7298 \\
\hline
\end{tabular}




\begin{tabular}{|c|c|c|c|c|}
\hline Zielprotein & Wirtstier & Klonalität & Hersteller & Katalognummer \\
\hline HSF1 & Kaninchen & polyklonal & Santa Cruz & sc9144 \\
\hline $\begin{array}{l}\text { Kaninchen IgG } \\
(\mathrm{H}+\mathrm{L})- \\
\text { Peroxidase } \\
\text { gekoppelt }\end{array}$ & Esel & polyklonal & Jackson & 711-036-152 \\
\hline p21 & Kaninchen & monoklonal & Cell Signaling & 2974 \\
\hline p53 & Maus & monoklonal & Santa Cruz & sc126 \\
\hline $\begin{array}{l}\text { Phosho-HSF1 } \\
\text { (S326) }\end{array}$ & Kaninchen & monoklonal & abcam & ab76076 \\
\hline $\begin{array}{l}\text { Phospho-AKT } \\
\text { (S473) }\end{array}$ & Kaninchen & monoklonal & Cell Signaling & 4060 \\
\hline $\begin{array}{l}\text { Phospho-Rb } \\
\text { (S807/8011) }\end{array}$ & Kaninchen & polyklonal & Cell Signaling & 9308 \\
\hline $\begin{array}{l}\text { Phospho-S6 } \\
\text { (S235/236) }\end{array}$ & Kaninchen & polyklonal & Cell Signaling & 2211 \\
\hline
\end{tabular}

\subsection{Methoden}

\subsubsection{Zellkultur}

Alle verwendeten Zelllinien wurden adhärent in Zellkulturschalen (Durchmesser $10 \mathrm{~cm}$ oder $15 \mathrm{~cm}$ ) bei $37^{\circ} \mathrm{C}$ und $5 \% \mathrm{CO}_{2}$ kultiviert. RKO- und LS513T-Zellen wurden in RPMI-1640Medium versetzt mit 10\% fetalem Kälber Serum (FCS), Penicillin/Streptomycin und Glutamin kultiviert. Für HCT116- und SW480-Zellen wurde McCoy`s-5A-Medium versetzt mit $10 \%$ FCS und Penicillin/Streptomycin verwendet (Tabelle 11). Alle Zellkulturarbeiten wurden unter sterilen Bedingungen unter einer Sicherheitswerkbank HERASAFE KS (Heraeus) mit laminarem Luftstrom durchgeführt. HSF1-überexprimierende Zelllinien wurden vor Beginn der Experimente in unserem Labor generiert.

Tabelle 11: Human Karzinomzelllinien aus Kolonkarzinomen.

\begin{tabular}{|l|l|l|l|}
\hline Zelllinie & p53 Status & HSF1 Status & Kulturmedium \\
\hline RKO & Wildtyp & Wildtyp & RPMI-1640 \\
\hline LS513T & Wildtyp & Wildtyp & RPMI-1640 \\
\hline HCT116 & Wildtyp & Wildtyp & McCoy's-5A \\
\hline HCT116 p53+/+ & Wildtyp & Wildtyp & McCoyss-5A \\
\hline HCT116 p53-/- & Deletion von Exon 2 & Wildtyp & McCoys-5A \\
\hline $\begin{array}{l}\text { HCT116 LentiORF- } \\
\text { Klon 13 }\end{array}$ & Wildtyp & Wildtyp & McCoyss-5A \\
\hline $\begin{array}{l}\text { HCT116 LentiORF- } \\
\text { Klon 14 }\end{array}$ & Wildtyp & Wildtyp & McCoys-5A \\
\hline $\begin{array}{l}\text { HCT116 LentiHSF1- } \\
\text { Klon 12 }\end{array}$ & Wildtyp & Überexpression & McCoyss-5A \\
\hline $\begin{array}{l}\text { HCT116 LentiHSF1- } \\
\text { Klon 21 }\end{array}$ & Wildtyp & Überexpression & McCoys-5A \\
\hline SW480 & Mutiert & Wildtyp & McCoys-5A \\
\hline U2OS & Wildtyp & Wildtyp & McCoys-5A \\
\hline
\end{tabular}


Initial wurden in $10 \%$ Dimethylsulfoxid (DMSO)/90\% FCS kryokonservierte Zellen aufgetaut und in Kultur genommen. Die Zellen wurden vorsichtig aufgetaut und mit dem zehnfachen Volumen des Kulturmediums versetzt. Nach Zentrifugation bei Raumtemperatur und 1000 revolutions per minute (RPM) für 5 min wurde der entstandene Überstand verworfen und das Zellpellet für die weitere Kultivierung in $10 \mathrm{ml}$ frischem Medium resuspendiert. Die Zellen wurden bis zur jeweils nächsten Passagierung in einer Zellkulturschale kultiviert.

Vor dem Beginn von Experimenten wurden die Zellen mindestens dreimal passagiert. Dabei wurde das Medium verworfen und die adhärenten Zellen mit $10 \mathrm{ml}$ autoklavierter phosphatbuffered saline (PBS) gewaschen, um FCS-Rückstände zu entfernen. Weiterhin wurden $2 \mathrm{ml}$ Trypsin zugesetzt und für mindestens 5 min bei $37^{\circ} \mathrm{C}$ inkubiert. Durch vorsichtiges Klopfen wurden die Zellen anschließend von der Kulturschale gelöst. Das Trypsin wurde durch Zugabe von $8 \mathrm{ml}$ frischen Medium inaktiviert, die Zellen durch Pipettieren vereinzelt und auf eine neue Kulturschale aufgeteilt. Abhängig von der verwendeten Zelllinie wurde dazu nur ein bestimmter Anteil der Zellsuspension weiterverwendet und mit neuem Medium verdünnt. Das Verhältnis der Volumina von Zellsuspension und frischem Medium ist in Tabelle 12 dargestellt. Das Medium wurde regelmäßig erneuert.

Tabelle 12: Verdünnung bei Zellpassage.

\begin{tabular}{|l|l|}
\hline Zelllinie & Verdünnung (Zellsuspension: Medium) \\
\hline HCT116 (alle Zelllinien) & $1: 20$ \\
\hline LS513T & $1: 5$ \\
\hline RKO & $1: 20$ \\
\hline
\end{tabular}

\subsection{2 siRNA-Transfektion}

Zellen wurden mit siRNA transfiziert. Die verwendeten Zellen wurden während des Passagierens gewonnen. Die entstandene Zellsuspension wurde in ein Reaktionsgefäß gefüllt und bei 1000 RPM für 3 min zentrifugiert. Der Überstand wurde verworfen und das Zellpellet in $10 \mathrm{ml}$ antibiotikafreiem Kulturmedium resuspendiert. Zur Ermittlung der Zellzahl wurden $10 \mu \mathrm{l}$ der Zellsuspension mit $10 \mu \mathrm{l}$ Trypanblau versetzt. Hiervon wurden 10 $\mu \mathrm{l}$ in eine Zählkammer gefüllt und die Zellzahl pro Mikroliter Zellsuspension wurde automatisch mit der Countess Automated Cell Counter (Thermo Fisher Scientific) ermittelt. Anschließend wurden die Zellen in 12er-Multiwellplatten kultiviert, hierfür wurde eine angepasste Zellzahl verwendet. Die verwendeten Zellzahlen sind in Tabelle 13 dargestellt. Für eine Kulturschale einer 12er-Multiwellplatte wurde ein Gesamtvolumen von $1 \mathrm{ml}$ verwendet. Dabei wurde die Zellsuspension zu antibiotikafreiem Kulturmedium zugegeben, sodass zunächst ein Gesamtvolumen von $800 \mu$ l entstand.

Zusätzlich wurden $200 \mu \mathrm{l}$ Transfektionslösung zugegeben. Diese wurde im Vorfeld erstellt. Zunächst wurden je $2 \mu \mathrm{l}$ Lipofectamie2000 mit $100 \mu \mathrm{l}$ FCS- und antibiotikafreiem Kutlturmedium gemischt und für 5 min bei Raumtemperatur inkubiert. Auch wurden in einem zweiten Schritt je 10 pmol siRNA zu weiteren $100 \mu$ FCS- und antibiotikafreiem 
Kulturmedium gegeben. Auch diese Lösung wurde gemischt und für $5 \mathrm{~min}$ bei Raumtemperatur inkubiert. Beide wurden zur Erstellung der Transfektionslösung zu gleichen Teilen gemischt. Vor Verwendung wurde dieser für 20 min bei Raumtemperatur inkubiert. Eine Übersicht der verwendeten siRNAs ist Tabelle 7 gegeben.

Die Zellen wurden für $24 \mathrm{~h}$ kultiviert. Anschließend wurde das Medium durch frisches Kulturmedium ersetzt. Die Zellen wurden vor der weiteren Verwendung für weitere $24 \mathrm{~h}$ oder 48 h kultiviert.

Tabelle 13: Zellzahl für siRNA-Transfektion in 12er-Multiwellplatten.

\begin{tabular}{|l|l|l|}
\hline Zelllinie & $\begin{array}{l}\text { Zellzahl pro Milliliter } \\
\text { Medium bei 48 h Protokoll }\end{array}$ & $\begin{array}{l}\text { Zellzahl pro Milliliter } \\
\text { Medium bei 72 h Protokoll }\end{array}$ \\
\hline HCT116 wt & $1,5 * 10^{5}$ & $1,1 * 10^{5}$ \\
\hline HCT116 p53 $+/+$ & $1,5 * 10^{5}$ & $/$ \\
\hline HCT116 p53-/- & $1,5 * 10^{5}$ & $/$ \\
\hline RKO & $1,2 * 10^{5}$ & $/$ \\
\hline
\end{tabular}

\subsubsection{Zellbehandlung}

Für die Zellbehandlung wurden Zellen während des Passagierens gewonnen. Dazu wurde zunächst wie in Kapitel 2.2.2 vorgegangen. Die Zellen wurden allerdings zunächst in 12erMultiwellplatten für $24 \mathrm{~h}$ kultiviert. Die verwendeten Zellzahlen sind Tabelle $14 \mathrm{zu}$ entnehmen. Anschließend wurde der Überstand verworfen und die adhärenten Zellen mit $1 \mathrm{ml}$ PBS gewaschen. Dann wurde frisches Kulturmedium mit dem jeweiligen Inhibitor gemischt und dies den Zellen zugegeben. Inhibitoren waren entweder in DMSO oder Wasser gelöst und wurden in unterschiedlichen Konzentrationen verwendet. Zellen wurden bis zur weiteren Analyse mit dem Inhibitor inkubiert. Tabelle 15 gibt einen Einblick in die verwendeten Inhibitoren und deren Behandlungskonzentrationen.

Tabelle 14: Zellzahl für Behandlung mit Inhibitoren in 12er-Multiwellplatten.

\begin{tabular}{|l|l|l|}
\hline Zelllinie & $\begin{array}{l}\text { Zellzahl pro Milliliter Medium } \\
\text { bei } 48 \text { h Protokoll }\end{array}$ & $\begin{array}{l}\text { Zellzahl pro Milliliter } \\
\text { Medium bei 72 h Protokoll }\end{array}$ \\
\hline HCT116 & $1,3 * 10^{5}$ & $/$ \\
\hline RKO & $1,3 * 10^{5}$ & $8,0 * 10^{4}$ \\
\hline
\end{tabular}

Tabelle 15: Inhibitoren zur Zellbehandlung.

\begin{tabular}{|l|l|l|}
\hline Inhibitor & Lösungmittel & $\begin{array}{l}\text { verwendete } \\
\text { Konzentrationen }\end{array}$ \\
\hline LEE011 & DMSO & $500 \mathrm{~nm}, 1 \mu \mathrm{M}, 5 \mu \mathrm{M}, 10 \mu \mathrm{M}$ \\
\hline LY294002 & DMSO & $25 \mu \mathrm{M}$ \\
\hline MG132 & DMSO & $10 \mu \mathrm{M}$ \\
\hline Nulin-3a & DMSO & $20 \mu \mathrm{M}$ \\
\hline PD0332991 & $\mathrm{H}_{2} \mathrm{O}$ & $1 \mu \mathrm{M}, 5 \mu \mathrm{M}, 10 \mu \mathrm{M}$ \\
\hline RG7112 & DMSO & $500 \mathrm{~nm}, 1 \mu \mathrm{M}, 5 \mu \mathrm{M}, 10 \mu \mathrm{M}$ \\
\hline RO3306 & DMSO & $500 \mathrm{~nm}, 1 \mu \mathrm{M}, 1,5 \mu \mathrm{M}, 2 \mu \mathrm{M}$, \\
& & $5 \mu \mathrm{M}, 10 \mu \mathrm{M}$ \\
\hline
\end{tabular}




\subsubsection{SILAC-Behandlung}

In Vorbereitung für die massenspektrometrische Analyse wurden Zellen nach dem Verfahren des stable isotope labeling by amino acids in cell culture (SILAC) konditioniert (Ong et al. 2002). Dazu wurden Zellen der Linie HCT116 LentiHSF1-Klon 12 (HSF1c1) verwendet. Es wurden drei Populationen geteilt, anschließend wurden diese mit je einem Konditionierungsmedium behandelt. Verwendet wurden drei SILAC-Konditionierungsmedien auf Basis des RPMI-Mediums. Diese erhielten wir von unseren Kooperationspartnern in der Arbeitsgruppe von Dr. Petra Beli (Institute of Molecular Biology Mainz). Die Konditionierungsmedien, die vom Hersteller frei von den Aminosäuren Arginin und Lysin, FCS und Antibiotika geliefert wurden, sind von unseren Kooperationspartnern mit Penicillin, FCS und Aminosäuren versetzt worden. Die Konditionierungsmedien unterschieden sich hinsichtlich der zugesetzten Aminosäuren Arginin und Lysin, die unterschiedlich schwere, stabile Isotope enthielten. Durch Verwendung unterschiedlicher Kombinationen der substituierten Aminosäuren entstanden drei verschiedene Konditionierungsmedien light (Arginin 0, Lysin 0), medium (Arginin 6, Lysin 0) und beary (Arginin 10, Lysin 8).

Zur Konditionierung wurden die Zellpopulationen ausschließlich mit dem jeweiligen Konditionierungsmedium kultiviert. Die Konditionierung wurde für mindestens fünf Zellpassagen durchgeführt, sodass eine vollständige Inkorporation der markierten Aminosäuren erfolgen konnte. Auch für den gesamten Zeitraum der experimentellen Verwendung wurden die Zellpopulationen ausschließlich mit dem jeweiligen Konditionierungsmedium kultiviert. Vor jedem durchgeführten Experiment wurden $2 * 10^{5}$ Zellen jeder Population mit PBS gewaschen und in flüssigem Stickstoff schockgefroren. Der Erfolg der Inkorporation wurde anhand dieser Zellprobe überprüft.

\subsubsection{Proteinextraktion aus kultivierten Zellen für Western-Blot-Analysen}

Für die Proteinextraktion aus kultivierten Zellen wurden diese zuvor in 12er-Multiwellplatten kultiviert. Vor Beginn der Proteinextraktion wurde der Grad der Konfluenz der Zellen und ihre Vitalität in den einzelnen Kulturschalen unter einem Durchlichtmikroskop abgeschätzt. Die Extraktion wurde gekühlt durchgeführt, alle Gefäße wurden dazu auf Eis gestellt. Mit einem Zellschaber wurden die adhärenten Zellen vorsichtig vom Boden der Kulturschalen gelöst. Anschließend wurde die Zellsuspension in ein sauberes Reaktionsgefäß überführt. Die Zellen wurden mit 1000 RPM für 3 min pelletiert. Der Überstand wurde verworfen und das Pellet mehrfach mit $1 \mathrm{ml}$ eiskaltem PBS gewaschen. Es wurde frischer RIPA-Puffer zugesetzt, der zuvor mit Complete ${ }^{\circledR}$ Protease Inhibitor Cocktail (Roche) versetzt wurde. Abhängig von Zelllinie und Zellkonfluenz wurde ein angepasstes Puffervolumen zwischen $100 \mu \mathrm{l}$ und $200 \mu \mathrm{l}$ verwendet. Durch vorsichtiges Auf- und Abpipettieren wurde das Zellpellet homogenisiert. Die Proben wurden anschließend für 30 min auf Eis inkubiert. Alle Proben wurden zusätzlich mit dem Sonopuls HD 2200 (Bandelin) homogenisiert und dann 
bei 13000 RPM für 3 min zentrifugiert. Der Überstand wurde als Proteinlysat bei $-80^{\circ} \mathrm{C}$ aufbewahrt.

\subsubsection{Konzentrationsbestimmung eines Proteinlysats}

Die Proteinkonzentration der hergestellten Proteinlysate wurde mit dem Pierce BCA Protein Assay Kit (Thermo Fisher Scientific) bestimmt. Dabei wurden die Angaben des Herstellers befolgt. Für jede Messung wurden $200 \mu \mathrm{l}$ der Bicinchoninsäure-Reagenz verwendet, diese wurden den Angaben des Herstellers folgend hergestellt. Pro Messung wurden $10 \mu$ l einer Probe verwendet, diese wurden gut mit der Bicinchoninsäure-Reagenz vermischt und bei $37^{\circ} \mathrm{C}$ für $30 \mathrm{~min}$ inkubiert. Anschließend wurde die Proteinkonzentration photometrisch bestimmt. Im Vorfeld wurde eine Eichgerade im Konzentrationsbereich 0,5 mg/ml bis 2,0 $\mathrm{mg} / \mathrm{ml}$ erstellt, die für die Bestimmung der Probenkonzentration verwendet wurde. Die Standards der Eichgerade wurden mit vom Hersteller geliefertem bovinen Serum-Albumin (BSA) erstellt.

Die Konzentrationsbestimmung der Proben erfolgte an technischen Duplikaten. Bei Konzentrationen außerhalb des Messbereichs wurden Verdünnungen der Probe verwendet.

\subsubsection{Proteinextraktion aus kultivierten Zellen für Ko-Immunpräzipitation}

Für die Proteinextraktion zur Ko-Immunpräzipitationen (CoIP) wurden Zellen in 6erMultiwellplatten, Kulturschalen mit $10 \mathrm{~cm}$ oder $15 \mathrm{~cm}$ Durchmesser kultiviert. Die Zellqualität wurde vor Beginn der Proteinextraktion visuell überprüft.

Die Extraktion wurde gekühlt durchgeführt, dazu wurden alle verwendeten Gefäße auf Eis gestellt. Das Kulturmedium wurde vorsichtig aspiriert und verworfen. Anschließend wurden die Zellen mit eiskaltem PBS gewaschen. Zur Zelllyse wurde frischer CoIP-Puffer zugegeben, der mit Complete ${ }^{\circledR}$ Protease Inhibitor Cocktail (Roche) substituiert wurde. Das zugegebene Puffervolumen wurde abhängig von Größe der Kulturschalen, Zelllinie und konfluenz angepasst. Mit einem Zellschaber wurden die adhärenten Zellen vom Kulturschalenboden gelöst und durch vorsichtiges Auf- und Abpipettieren mit dem Puffer homogenisiert. Die Proben wurden in ein sauberes Reaktionsgefäß übertragen und für 30 min auf Eis inkubiert. Daraufhin wurden die Proben mit dem Sonopuls HD 2200 (Bandelin) homogenisiert und bei 13000 RPM für 3 min zentrifugiert. Der Überstand wurde in ein neues Reaktionsgefäß übertragen und als fertiges Lysat zur CoIP weiterverwendet.

\subsubsection{Ko-Immunpräzipitation}

Die Proteinkonzentration wurde mit dem Pierce BCA Protein Assay Kit bestimmt wie in Kapitel 2.2.6 beschrieben. Proben mit einer größeren Proteinkonzentration als $1 \mathrm{mg} / \mathrm{ml}$ wurden mit Puffer verdünnt. Anschließend wurden die Proben aliquotiert, sodass Volumina mit einem Proteingehalt von $1 \mathrm{mg}$ entstanden. Proben, welche für die spätere 
massenspektrometrische Analyse erstellt wurden, wurden so aliquotiert, dass ein Proteingehalt von $10 \mathrm{mg}$ mit einer Konzentration von $1 \mathrm{mg} / \mathrm{ml}$ vorlag. Anschließend wurden $50 \mu \mathrm{l}$ frische Protein-A Sepahrose CL4B (PAS) pro Milliliter Probenvolumen für die Vorreinigung zugegeben. PAS wurde zuvor in CoIP-Puffer äquilibriert. Die Vorreinigung wurde für $1 \mathrm{~h}$ bei $4^{\circ} \mathrm{C}$ durchgeführt, dabei wurden die Proben rotierend gemischt. Die Proben wurden bei 1000 RPM für 4 min zentrifugiert und der Überstand in ein neues Reaktionsgefäß überführt. Ein $50 \mu \mathrm{l}$ Aliquot der Proben wurde bei $-80^{\circ} \mathrm{C}$ als sogenanntes Input gelagert. Anschließend wurde der Primärantikörper zugegeben und die Proben über Nacht bei $4^{\circ} \mathrm{C}$ rotierend gemischt, wobei sich Antigen-Antikörper-Komplexe bilden sollten. Als Kontrollantikörper wurde ein gegen Hämagglutinin-Tag (HA-Tag) gerichteter Antikörper oder ein Antikörper spezifisch für Maus-Immunglobulin verwendet. Tabelle 16 gibt einen Überblick über die für CoIP verwendeten Antikörper sowie die eingesetzte Antikörpermenge.

Tabelle 16: Antikörper für CoIP.

\begin{tabular}{|l|l|l|l|}
\hline Zielstruktur & Hersteller & Katalognummer & $\begin{array}{l}\text { Verdünnung }(\boldsymbol{\mu g} \\
\text { AB } / \mathbf{m} \text { Probe) }\end{array}$ \\
\hline CDK4 & abcam & ab68266 & 4,25 \\
\hline HA-Tag & Cell Signalling & 3724 & 2 \\
\hline HSF1 & Santa Cruz & sc-9144 & 3 \\
\hline $\begin{array}{l}\text { Phospho-HSF1 } \\
\text { (Ser326) }\end{array}$ & abcam & ab76076 & 2 \\
\hline
\end{tabular}

Nach Abschluss der Inkubationszeit wurden $20 \mu \mathrm{l}$ PAS pro Milliliter Probenvolumen zugegeben und die Proben für $1 \mathrm{~h}$ bei $4^{\circ} \mathrm{C}$ rotierend inkubiert. Hierbei werden AntigenAntikörper-Komplexe durch PAS gebunden, was die anschließende Präzipitation ermöglicht. Die Proben wurden bei 1000 RPM für 5 min zentrifugiert und der Überstand verworfen. Das entstandene Pellet wurde zweimal mit einem dem Probenvolumen entsprechenden Volumen CoIP-Puffer gewaschen. Anschließend wurde das Pellet einmal mit einem dem Probenvolumen entsprechenden Volumen CoIP-Puffer gewaschen, der mit Complet ${ }^{\circledR}$-Protease-Inhibitor-Cocktail (Roche) versetzt war.

Das Pellet von Proben, die für die spätere massenspektrometrische Analyse verwendet wurden, ist nach vollständiger Aspiration des Puffers mit flüssigem Stickstoff schockgefroren und dann bei $-80^{\circ} \mathrm{C}$ bis zur weiteren Verwendung gelagert worden. Das Pellet von Proben, die für Western Blots verwendet wurden, wurde durch Zugabe von $30 \mu \mathrm{l}$ dreifach konzentriertem Laemmli Puffer eluiert und dann bei $-20^{\circ} \mathrm{C}$ bis zur weiteren Verwendung gelagert.

\subsubsection{Polyacrylamidgelelektrophorese}

Eine diskontinuirliche, denaturierende Polyacrylamidgelelektrophorese wurde nach dem erstmals von Ulrich Laemmli beschriebenen Protokoll durchgeführt (Laemmli 1970). Für die 
Elektrophorese wurden entweder das Hoefer-Mini-VE-Vertical-Electrophoresis-System (Amersham Biosciences) oder das Mini-Protean Tetra Cell System (Biorad) verwendet. Für das zuerst genannte System wurden Polyacrylamidgele mit einer Stärke von $1 \mathrm{~mm}$ verwendet, für das zuletzt genannte System wurden Gele mit einer Stärke von 1,5 mm verwendet.

Die Polyacrylamidgele wurden in einer vom Hersteller bezogenen, modifizierten Rahmenkonstruktion zwischen zwei Glasplatten gegossen. Dazu wurde zuerst das Trenngel gegossen und mit Isopropanol überschichtet. Nach vollständiger Polymerisierung des Gels wurde der Isopropanol sorgfältig entfernt und das Sammelgel direkt auf das Trenngel gegossen. Sofort wurde ein vom Hersteller bezogener Plastikkamm eingebracht, der zehn Sammeltaschen im Gel formte. Eine Sammeltasche des Hoefer-Mini-VE-VerticalElectrophoresis-Systems hatte ein maximales Volumen von ca. $40 \mu$, während eine Sammeltasche des Mini-Protean Tetra Cell Systems ca. $60 \mu \mathrm{l}$ fasste. Die vollständig polymerisierten Gele wurden bis zur weiteren Verwendung bei $4^{\circ} \mathrm{C}$ in einer feuchten Kammer aufbewahrt. Es wurden Trenngele mit einer Acrylamidkonzentration von $10 \%$ bis $12 \%$ eingesetzt. Die Acrylamidkonzentration des Sammelgels betrug $4 \%$. Die Zusammensetzung der Gele ist in Tabelle 17 dargestellt.

Zur Elektrophorese wurde Proben mit angeglichenen Proteinmengen eingesetzt. Dazu wurde die Proteinkonzentration der Proteinlysate zuvor wie in Kapitel 2.2.6 bestimmt und ein angepasstes Volumen des Proteinlysats verwendet. Zusätzlich wurde das Volumen der Proben mit Ripa-Puffer untereinander ausgeglichen und mit ausreichend Laemmli-Puffer gemischt. Vor Verwendung wurden alle Proben vollständig aufgetaut und nach Zugabe des Laemmli-Puffers für $5 \mathrm{~min}$ bei $95^{\circ} \mathrm{C}$ denaturiert. Zur Elektrophorese wurden Probenvolumina mit einem Proteingehalt zwischen 25 bis $40 \mu \mathrm{g}$ verwendet. Die pageruler prestained protein ladder (Thermo Fisher Scientific) wurde als Proteingrößenstandard eingesetzt, leere Geltaschen wurden mit einem Gemisch aus Ripa-Puffer und Laemmli-Puffer gefüllt.

Polyacrylamidgele wurden vertikal in die Kammer eingesetzt, die Kammern mit Laufpuffer befüllt, der Kamm entfernt und die Proben in die vorgesehenen Geltaschen gefüllt. Die Elektrophorese wurde bei $80 \mathrm{~V}$ begonnen und fortgesetzt bis eine sichtbare Auftrennung des Proteingrößenstandards im Trenngel begann. Die Spannung wurde dann auf $120 \mathrm{~V}$ erhöht und die Elektrophorese fortgesetzt bis ein gewünschter Grad der Auftrennung erreicht wurde. Dieser war nach Herauslaufen der 10 kDa Bande des Größenstandards, teils aber auch erst nach Herauslaufen der $25 \mathrm{kDa}$ Bande erreicht.

Tabelle 17: Zusammensetzung der Polyacrylamidgele.

\begin{tabular}{|l|l|l|}
\hline Acrylamidkonzentration & Gelkomponenten & Volumen \\
\hline $4 \%$ (Sammelgel) & $1,5 \mathrm{M}$ Tris - HCl, $\mathrm{pH} 6,8$ & $0,6 \mu \mathrm{l}$ \\
\hline & $10 \%$ APS & $50 \mu \mathrm{l}$ \\
\hline & $10 \%$ SDS & $75 \mu \mathrm{l}$ \\
\hline & Rotiphorese Gel 30 & $0,68 \mathrm{ml}$ \\
\hline & Tetramethylethylendiamin & $5 \mu \mathrm{l}$ \\
\hline & Wasser & $3,4 \mathrm{ml}$ \\
\hline $10 \%$ (Trenngel) & $0,5 \mathrm{M}$ Tris $-\mathrm{HCl}, \mathrm{pH} 8,8$ & $4 \mathrm{ml}$ \\
\hline
\end{tabular}




\begin{tabular}{|l|l|l|}
\hline Acrylamidkonzentration & Gelkomponenten & Volumen \\
\hline & $10 \%$ APS & $75 \mu \mathrm{l}$ \\
\hline & $10 \%$ SDS & $160 \mu \mathrm{l}$ \\
\hline & Rotiphorese Gel 30 & $5,7 \mathrm{ml}$ \\
\hline & Tetramethylethylendiamin & $5 \mu \mathrm{l}$ \\
\hline & Wasser & $4,8 \mu \mathrm{l}$ \\
\hline $12 \%$ (Trenngel) & $0,5 \mathrm{M}$ Tris $-\mathrm{HCl}, \mathrm{pH} 8,8$ & $4 \mathrm{ml}$ \\
\hline & $10 \%$ APS & $75 \mu \mathrm{l}$ \\
\hline & $10 \%$ SDS & $160 \mu \mathrm{l}$ \\
\hline & Rotiphorese Gel 30 & $6,7 \mathrm{ml}$ \\
\hline & Tetramethylethylendiamin & $5 \mu \mathrm{l}$ \\
\hline & Wasser & $3,7 \mathrm{ml}$ \\
\hline
\end{tabular}

\subsubsection{Western Blot \& Signal-Detektion}

Nach Beendigung der Elektrophorese wurde das Polyacrylamidgel aus der Kammer entfernt und ein Western-Blot-Transfer angeschlossen. Der Transfer wurde im Hoefer-Mini-VETransfer-Tank (Amersham Biosciences) durchgeführt. Dazu wurde in dieser Reihenfolge ein sauberer Schwamm, drei Whatman-Papiere, das Gel, die Membran, drei weitere WhatmanPapiere und ein Schwamm zwischen zwei Plastikstücken fixiert. Auf ein luftblasenfreies Aufbringen der Membran auf das Gel wurde geachtet. Die Membran sowie die WhatmanPapiere wurden zuvor auf eine dem Gel angepasst Größe geschnitten, alle Komponenten wurden sorgfältig in Puffer getränkt und so in der Kammer positioniert, dass sich das Gel zwischen Kathode und Membran befand. Die Rotation von Gel und Membran zueinander wurde vermerkt. Anschließend wurde der Tank zwischen Anode und Kathode der Kammer mit eiskaltem Transferpuffer gefüllt und alles im Tank befestigt. Der Transfer wurde auf Eis gekühlt in einer Kühlkammer bei $4^{\circ} \mathrm{C}$ durchgeführt, wobei eine konstante Spannung zwischen $80 \mathrm{~V}$ und $100 \mathrm{~V}$ für $2 \mathrm{~h}$ angelegt wurde.

Anschließend wurde die Membran kurz in TBST gewaschen, dann für 30 min bei Raumtemperatur in Block-Puffer inkubiert und noch einmal kurz in TBST gewaschen. Die Primärantikörperlösung wurde durch Verdünnung des Primärantikörpers in Block-Puffer hergestellt. Sofern nicht anders vom Hersteller des Antikörpers gefordert, wurde BlockPuffer mit $5 \%$ Milchpulver verwendet. Sofern vom Hersteller gefordert sowie für Antikörper mit phosphorylierter Zielstruktur wurde Block-Puffer mit $5 \%$ BSA verwendet. Zur Inkubation wurden je $10 \mathrm{ml}$ der Primärantikörperlösung mit Stücken der Nitrocellulosemembran in einem Reaktionsgefäß inkubiert. Die Membran wurde zuvor anhand des Größenstandards zerschnitten und nur Stücke, die den bekannten Größenbereich der Zielstruktur des Antikörpers enthielten, wurden zur Inkubation verwendet. Die Membranstücke wurden rotierend bei $4^{\circ} \mathrm{C}$ über Nacht mit der Primärantikörperlösung inkubiert, wobei darauf geachtet wurde, dass während der Inkubation alle Teile der Membran gleichmäßig mit Lösung bedeckt wurden. Alternativ wurde die Inkubation auch für $1 \mathrm{~h}$ bei Raumtemperatur durchgeführt. Nach Abschluss der Inkubationszeit wurde die Membranstücke dreimal für je 20 min bei Raumtemperatur mit frischem TBST gewaschen. Anschließend wurden die Membranstücke mit dem 
Sekundärantikörper inkubiert. Der Sekundärantikörper wurde in Block-Puffer mit $5 \%$ Milchpulver verdünnt. Die Inkubation erfolgte analog zur Primärantikörperinkubation für $1 \mathrm{~h}$ bei Raumtemperatur. Abschließend wurden die Membranstücke dreimal für $20 \mathrm{~min}$ mit TBST gewaschen.

Als Ladekontrolle wurde Aktin oder HSC70 verwendet. Bei der Inkubation wurden sowohl Primär-als auch Sekundärantikörper gleichzeitig in Blockpuffer mit $5 \%$ Milchpulver für $1 \mathrm{~h}$ bei Raumtemperatur eingesetzt. Anschließend wurde die Membran sorgfältig für dreimal 20 min mit TBST gewaschen.

Zur Signalentwicklung wurden die Membranstücke sorgfältig und gleichmäßig mit Elektrochemolumineszenz-Entwicklungslösung bedeckt. Abhängig von der Stärke des erwarteten Signals wurden dazu entweder Immobilon Western HRP Substrat (Merck Millipore) oder SuperSignal West Femto Maximum Sensitivity Substrate (Thermo Fisher Scientific) verwendet. Für beide Lösungen wurden den Angaben der Hersteller entsprechend zwei enthaltene Komponenten zu gleichen Teilen gemischt, die entstandene Lösung wurde dann sofort verwendet. Die benetzte Membran wurde blasenfrei in Plastikschlauchfolie eingeschlagen. Zur Detektion des Signals wurde ein ChemolumineszenzBildentwicklungssystem (Intas Science Imaging Instruments) verwendet und die Entwicklungszeit wurde je nach Signalintensität angepasst. Die Bilder wurden mit Adobe Photoshop (Adobe) bearbeitet. Dabei wurde das Signal invertiert und die Gesamtintensität für eine bessere Beurteilbarkeit angepasst.

Tabelle 18: Antikörper für Western Blots.

\begin{tabular}{|l|l|l|l|}
\hline Zielstruktur & Hersteller & Katalognummer & $\begin{array}{l}\text { Verdünnung in } \\
\text { Blockpuffer }\end{array}$ \\
\hline Aktin & abcam & ab6276 & $1: 10000$ \\
\hline CDK4 & abcam & ab68266 & $1: 500$ \\
\hline HSC70 & Santa Cruz & sc7298 & $1: 3000$ \\
\hline p21 & Cell Signaling & 2947 & $1: 1000$ \\
\hline p53 & Santa Cruz & sc -126 & $1: 1000$ \\
\hline $\begin{array}{l}\text { Phospho-Akt } \\
\text { (Ser473) }\end{array}$ & Cell Signaling & 4060 & $1: 1000$ \\
\hline $\begin{array}{l}\text { Phospho-HSF1 } \\
\text { (Ser326) }\end{array}$ & abcam & ab76076 & $1: 1000$ \\
\hline $\begin{array}{l}\text { Phospho-Rb } \\
\text { (Ser807/8011) }\end{array}$ & Cell Signaling & 9308 & $1: 1000$ \\
\hline $\begin{array}{l}\text { Phospho-S6 } \\
\text { (Ser235/236) }\end{array}$ & Cell Signaling & 2211 & $1: 2000$ \\
\hline
\end{tabular}

\subsubsection{1 mRNA-Isolierung aus kultivierten Zellen mit Konzentrationsbestimmung}

Zur Isolierung von mRNA wurde TRIzol ${ }^{\circledR}$-Reagenz (Thermo Fisher Scientific) verwendet. Dabei wurden die vom Hersteller empfohlenen Vorgaben berücksichtigt.

Für die Extraktion von mRNA wurden Zellen in 12er-Multiwellplatten kultiviert. Vor Beginn der Extraktion wurden die kultivierten Zellen nach den in Kapitel 2.2.5 beschriebenen 
Qualitätsmerkmalen kontrolliert und beim Arbeiten wurde eine Kontamination der Proben mit fremder RNA streng vermieden. Die Zellen wurden gekühlt zu einer Sicherheitswerkbank transportiert und die Isolierung wurde hierunter durchgeführt. Das Medium wurde verworfen und $1 \mathrm{ml}$ TRIzol ${ }^{\circledR}$-Reagenz pro Kulturschale zur Inkubation bei Raumtemperatur zugefügt. Durch Auf- und Abpipettieren wurde eine Homogenisierung der Probe erreicht und anschließend wurden die Proben in ein sauberes Reaktionsgefäß überführt. Weitere Arbeiten konnten zunächst ungekühlt fortgesetzt werden. Nach 5 min Inkubationszeit bei Raumtemperatur wurden $200 \mu \mathrm{l}$ Chloroform zugegeben und die Proben für $15 \mathrm{sec}$ kräftig geschüttelt. Anschließend wurden die Proben für weitere $3 \mathrm{~min}$ bei Raumtemperatur inkubiert und dann bei $12000 \mathrm{RPM}$ und $4^{\circ} \mathrm{C}$ für 15 min zentrifugiert. Es resultierte eine dreischichtige Probe mit einer oberen wässrigen, einer mittleren weißlichen Phase und einer unteren phenolhaltigen Phase. Die obere wässrige Phase, welche die RNA enthielt, wurde in ein neues Probengefäß überführt und weiterverwendet.

Die Proben wurden mit $500 \mu \mathrm{l}$ Isopropanol gemischt und für 10 min bei Raumtemperatur inkubiert, bevor sie für 10 min zentrifugiert wurden. Nach diesem Schritt wurde ein durchsichtiges Pellet aus RNA am Gefäßboden sichtbar. Der Überstand wurde vorsichtig aspiriert und das Pellet einmalig mit $75 \%$ Ethanol gewaschen, bevor es in $20 \mu \mathrm{l}$ nucleaseund RNAse-freiem Wasser resuspendiert wurde. Abschließend wurden die Proben für 10 min bei $50^{\circ} \mathrm{C}$ mit geöffnetem Deckel inkubiert, um eine vollständige Evaporation der eingesetzten Alkohole zu gewährleisten.

Die RNA-Konzentrationsbestimmung wurde mit dem NanoDrop ND-1000 Spectrophotometer (Thermo Fisher Scientific) durchgeführt, wozu $2 \mu$ l Probe eingesetzt worden sind. Die Bestimmung erfolgte anhand des Extinktionswertes bei $260 \mathrm{~nm}$, es erfolgte eine automatische Ausgabe der Konzentration durch die NanoDrop Software. Die isolierte mRNA wurde bei $-80^{\circ} \mathrm{C}$ gelagert.

\subsubsection{Reverse Transkription}

Für jede Synthese von komplementärer DNA (cDNA) mittels reverser Transkription wurde $1 \mu \mathrm{g}$ isolierter mRNA verwendet und mit RNAse-freiem Wasser auf ein Volumen von $10 \mu \mathrm{l}$ verdünnt. Anschließend wurde eine erste Reaktionslösung aus Primern und dNTPs hergestellt, von dem $6 \mu \mathrm{l}$ zu jeder Probe zugegeben wurde. Die Proben wurden dann bei $70^{\circ} \mathrm{C}$ für 5 min inkubiert, kurz herunterzentrifugiert und dann auf Eis gestellt. Von einer zuvor hergestellten, zweiten Reaktionslösung wurden $4 \mu \mathrm{l}$ zugegeben und gut mit den Proben gemischt, die dann bei $42^{\circ} \mathrm{C}$ für $1 \mathrm{~h}$ inkubiert wurden. Tabelle 19 gibt einen Überblick über die verwendeten Reaktionslösungen. Direkt daran anschließend wurden die Proben bei $85^{\circ} \mathrm{C}$ für 5 min inkubiert bevor $130 \mu \mathrm{l}$ RNAse-freies Wasser zugegeben wurden. Die fertigen Proben wurden bei $-20^{\circ} \mathrm{C}$ aufbewahrt. 
Tabelle 19: Zusammensetzung der Reaktionslösungen für cDNA-Synthese.

\begin{tabular}{|l|l|}
\hline $\begin{array}{l}\text { Reaktionslösung } 1 \text { für Reverse } \\
\text { Transkription }\end{array}$ & Volumen $(\boldsymbol{\mu l})$ pro Probe \\
\hline $\begin{array}{l}\text { Gemischte Primer }(50 \mu \mathrm{M} \text { Poly T, } 15 \mu \mathrm{M} \\
\text { Zufällige Primer) }\end{array}$ & 2 \\
\hline 2,5 mM dNTPs & 4 \\
\hline $\begin{array}{l}\text { Reaktionslösung } 2 \text { für Reverse } \\
\text { Transkription }\end{array}$ & 2 \\
\hline $\begin{array}{l}\text { M-MuLV Reverse Transcriptase Reaction } \\
\text { Buffer }\end{array}$ & 2 \\
\hline RNase Inhibitor & $0,25(10 \mathrm{U})$ \\
\hline M-MuLV Reverse Transcriptase & $0,125(25 \mathrm{U})$ \\
\hline
\end{tabular}

\subsubsection{Quantitative real-time PCR}

Die Expression ausgewählter Gene wurde quantitativ analysiert. Hierbei wurde die Expression spezifischer mRNA quantitativ nachgewiesen. Dazu wurde der interkalierende Fluoreszenzfarbstoff SYBR-Green verwendet. Während der PCR-Reaktion wird die Fluoreszenz des an doppelsträngige DNA gebundenem SYBR-Greens ausgelesen. Die Fluoreszenzintensität verhält sich direkt proportional zur Menge neu amplifizierter DNA. Die Fluoreszenz von SYBR-Green wurde automatisch durch einen qPCR-Zykler ausgelesen und protokolliert. Der Beginn des exponentiellen Anstiegs der Fluoreszenzintensität über den Hintergrundwert wurde als gycle threshold $(\mathrm{Ct})$ aufgenommen, dieser markiert den Beginn der exponentiellen Vervielfältigung eines spezifischen PCR-Produktes. Wenn zu Beginn der Reaktion viel der spezifisch nachzuweisenden cDNA vorlag, wurde der Ct früh erreicht, bei einem geringen Gehalt an cDNA entsprechend später. Um die Expression betrachteter Gene zu normalisieren, wurde diese zu der Expression des Genes RPLPO ins Verhältnis gesetzt. Diese kodiert für ein ribosomales Protein und dessen Expression ist nahezu unabhängig von Kultur- und Behandlungsbedingungen. Weiterhin wurde reines Wasser als Negativkontrolle verwendet. Verglichen wurde die Expression eines Gens zwischen einer Kontrolle und einer Probe. Dazu wurden folgende, von der $\Delta \Delta$ Ct-Methode abgeleitete Formeln verwendet:

$\Delta C t($ Probe $)=C t($ Probe: Gene of Interest $)-C t($ Probe $: R P L 0)$

$\Delta C t($ Kontrolle $)=C t($ Kontrolle: Gene of Interest $)-C t($ Kontrolle: $R P L 0)$

$\Delta \Delta \mathrm{Ct}=\Delta \mathrm{Ct}($ Probe $)-\Delta \mathrm{Ct}($ Kontrolle $)$

Normalisierte rel. Expression $=2^{-\Delta \Delta C t}$

Bei Werten $>1$ war von einer Überexpression gegenüber der Kontrolle auszugehen, bei Werten $<1$ entsprechend umgekehrt.

Zum Nachweis spezifischer cDNA wurden anhand der mRNA-Sequenz Primer entworfen, wozu das Primer-BLAST Programm des National Center for Biotechnology Information genutzt wurde. Entworfene Primer überspannten i. d. R. Exon-Exon-Kontakte, womit 
versucht wurde eine für Analysezwecke ungewollte Amplifikation von genomischer DNA auszuschließen. Primer wurden von Metabion International AG (Planegg/Steinkirchen) bezogen. Die Primerqualität wurde zusätzlich in einem Vorversuch untersucht. Dabei wurde eine cDNA-Verdünnungsreihe verwendet (1:1, 1:2, 1:4, 1:8, 1:16). Es wurden nur solche Primerpaare weiterbenutzt, bei deren Verwendung sich ein Anstieg des Ct um 1 pro Verdünnungsschritt zeigte und deren Reaktionsprodukte eine hohe, gleichbleibende Schmelztemperatur hatten. Weiterhin wurden nur solche Primerpaare verwendet, deren theoretisches Reaktionsamplifikat eine Länge von 300 bp nicht signifikant überschritt. Hierdurch konnte eine zusätzliche Spezifität für cDNA gegenüber genomischer DNA erreicht werden, da aufgrund der kurzen Elongationszeit des verwendeten PCR-Protokolls eine Amplifikation längerer Produkte vermieden wurde, die z. B. bei unspezifischen Bindungen der Primer entstehen könnten.

Die qPCR-Reaktionen wurden auf einer 96er-Multiwellplatte durchgeführt. Es wurde je $3 \mu \mathrm{l}$ cDNA-Probe eingesetzt. Primerpaare wurden im Verhältnis 1:10 in Wasser verdünnt, forward- und backward-Primer wurden dabei zu gleichen Teilen gemischt. Für die Reaktionen wurde ein Reaktionsgemisch aus qPCR-Puffer, verdünnten und gemischten Primern und Wasser angesetzt, von diesem wurden je Reaktion $22 \mu$ verwendet. Tabelle 20 stellt die Zusammensetzung des Reaktionsgemisches für qPCR dar.

Alle Komponenten wurden unter Kühlung und Lichtschutz zusammengeführt, dabei wurden Verunreinigungen streng vermieden. Fertige 96er-Multiwellplatte wurden mit optisch klarer Folie versiegelt und in den Thermocycler eingebracht. Verwendet wurde das CFX96 Touch Real-Time PCR Detection System (Biorad). Das verwendete Protokoll begann mit einer initialen Phase bei $95^{\circ} \mathrm{C}$ für $5 \mathrm{~min}$, dann folgten 40 Zyklen bei $95^{\circ} \mathrm{C}$ für $15 \mathrm{sec}$ und $60^{\circ} \mathrm{C}$ für $1 \mathrm{~min}$. Abschließend wurden in $0,5^{\circ} \mathrm{C}$ Schritten Schmelzkurven von $60^{\circ} \mathrm{C}$ bis $95^{\circ} \mathrm{C}$ aufgezeichnet.

Tabelle 20: Reaktionsmix für qPCR.

\begin{tabular}{|l|l|}
\hline Reaktionsgemisch für qPCR & Volumen $(\boldsymbol{\mu l})$ pro Probe \\
\hline qPCR-Puffer & 14 \\
\hline Verdünnte und gemischte Primer & 1 \\
\hline dd $\mathrm{H}_{2} \mathrm{O}$ & 7 \\
\hline Totales Volumen & 22 \\
\hline
\end{tabular}

\subsubsection{Plasmid-Transfektion}

Humane Zellen wurden mit Plasmid-DNA transfiziert. Dazu wurden Zellen während des Passagierens auf einer 12er-Multiwellplatte ausgebracht und für $24 \mathrm{~h}$ kultiviert. Anschließend wurden die Transfektion mit Plasmid-DNA durchgeführt.

Zunächst wurde pro Transfektionsansatz $4 \mu \mathrm{l}$ Lipofectamine2000 und $100 \mu \mathrm{l}$ zusatzfreies Medium gemischt und mehrere Male vorsichtig invertiert. Außerdem wurde $800 \mathrm{ng}$ PlasmidDNA und $100 \mu$ zusatzfreies Medium gemischt. Beide wurden für 5 min bei Raum- 
temperatur inkubiert, im Verhältnis 1:1 gemischt und nach sorgfältigem Invertieren für weitere 20 min bei Raumtemperatur inkubiert.

Die Zellen wurden mit $1 \mathrm{ml}$ PBS gewaschen. Anschließend wurden $800 \mu \mathrm{l}$ antibiotikafreies Medium und pro Transfektionsansatz je $200 \mu \mathrm{l}$ der fertigen Transfektionslösung zugegeben. Die Zellen wurden für weitere $24 \mathrm{~h}$ unter Normalbedingungen kultiviert, jedoch wurde das Medium bereits nach $6 \mathrm{~h}$ verworfen und durch frisches Kulturmedium ersetzt. Nach Abschluss von $24 \mathrm{~h}$ wurden weitere Experimente angeschlossen.

\subsubsection{Hitzeschockbehandlung von humanen Zellen}

Humane Zellen wurden einer Hitzeschockbehandlung bei $42^{\circ} \mathrm{C}$ ausgesetzt. Dazu wurden vollständig adhärente Zellen verwendet, die zuvor für mindestens $24 \mathrm{~h}$ in einer 12erMultiwellplatte kultiviert und ggf. behandelt wurden. Die Kulturplatten wurden für $1 \mathrm{~h}$ bei $42^{\circ} \mathrm{C}$ und anschließend für weitere $2 \mathrm{~h}$ bei $37^{\circ} \mathrm{C}$ inkubiert. Nach Abschluss der Behandlung erfolgte die Zellaufbereitung.

\subsubsection{Dualer Luciferase-Assay}

Zur Analyse der HSF1-Aktivität wurde ein dualer Luciferase-Assay verwendet. Dabei wurden RKO- und HCT116-Zellen verwendet. Diese wurden in einer 12er-Multiwellplatte ausgebracht und mit je $800 \mathrm{ng}$ Plasmid-DNA transfiziert (Tabelle 21). Am zweiten Versuchstag erfolgte die Behandlung mit verschiedenen Inhibitoren (

Tabelle 22). Von drei Ansätzen, welche zum Transfektionschema-A gehörten, wurde je einer mit DMSO, $20 \mu \mathrm{M}$ Nutlin-3a bzw. $10 \mu \mathrm{M}$ PD0332991 behandelt. Nach insgesamt $48 \mathrm{~h}$ wurden manche Zellen einem Hitzeschock ausgesetzt, die andere Gruppe wurde unter normalen Bedingungen weiterkultiviert.

Tabelle 21: Schema für die Transfektion mit Plasmid-DNA.

\begin{tabular}{|l|l|}
\hline Transfektionschema & Verwendete Plasmide \\
\hline A & 500 ng pGl4.41 \\
& 100 ng pRl - Tk \\
& 200 ng pcDNA3.1 \\
\hline B & 500 ng pGl4.41 \\
& 100 ng pRl - Tk \\
\hline C & 200 ng pSUPER-p53 p53 \\
& 500 ng pG14.41 \\
& 100 ng pRl - Tk \\
& 100 ng pcDNA p53 \\
& 100 ng pcDNA3.1 \\
\hline
\end{tabular}


Tabelle 22: Schema für Zellbehandlung nach erfolgter Transfektion.

\begin{tabular}{|l|l|l|l|}
\hline Transfektionschema & \multicolumn{2}{|l|}{ Inhibitorbehandlung } \\
\hline A & DMSO & $20 \mu \mathrm{M}$ Nutlin-3a & $10 \mu \mathrm{M}$ PD0332991 \\
\hline B & DMSO & & \\
\hline C & DMSO & & \\
\hline $\begin{array}{l}\text { Kontrollgruppe ohne } \\
\text { Transfektion }\end{array}$ & DMSO & Unbehandelt & \\
\hline
\end{tabular}

Nach Abschluss der Transfektion und Behandlung wurden die Zellen für einen dualen Luciferase-Assay verwendet. Da die Expression der Firefly-Luciferase vom Plasmid pG14.41luc2P/HSE durch multiple HSEs im Promotor reguliert wird, ist die Expression der Luciferase direkt von der Bindung von HSF1 an die HSEs abhängig. Um unterschiedliche Transfektionseffizienz als Ursache für Differenzen in der Luciferase-Aktivität auszuschließen, wurde zusätzlich die Aktivität der Renilla-Luciferase quantifiziert und der Quotient aus beiden gebildet. Die Renilla-Luciferase wurde vom Plasmid pRL-TK konstitutiv durch den Herpes-Simplex-Virus-Thymidinkinase-Promotor exprimiert.

Die Zellen wurden für die Durchführung des dualen Luciferase-Assays auf Eis gekühlt und mit einem Zellschaber vom Boden des Kulturgefäßes gelöst. Anschließend wurde das Volumen in ein sauberes Reaktionsgefäß überführt und bei $3000 \mathrm{RPM}$ und $4^{\circ} \mathrm{C}$ für 5 min zentrifugiert. Der Überstand wurde verworfen, die Zellen vorsichtig in $100 \mu \mathrm{l}$ passiv-lysis-buffer resuspendiert und für $15 \mathrm{~min}$ bei Raumtemperatur inkubiert. Die Proben wurden bei 14000 RPM zentrifugiert und der zellfreie Überstand als Proben weiterverwendet. Je $20 \mu l$ des Probenvolumens wurden für eine Messung in ein well der OptiPlate-96 überführt. Die Messungen wurden in technischen Triplikaten durchgeführt und als Kontrolle wurde Wasser und das Lysat von nicht transfizierten, unbehandelten Zellen verwendet. Die Platte wurden in das Centro LB 960 Mirkoplatten Luminometer (Berthold Technologies) überführt, das Messprotokoll ist in Tabelle 23 dargestellt.

Tabelle 23: Messprotokoll für den dualen Luciferase-Assay.

\begin{tabular}{|l|l|l|}
\hline Aktion & Zeit (s) & Volumen $(\boldsymbol{\mu l})$ \\
\hline Zugabe Firefly-Puffer & & 100 \\
\hline Verzögerung & 2 & \\
\hline $\begin{array}{l}\text { Quantifizierung Firefly } \\
\text { Luciferase Aktivität }\end{array}$ & 20 & \\
\hline Verzögerung & 2 & 100 \\
\hline Zugabe Renilla-Puffer & 2 & \\
\hline Verzögerung & 20 & \\
\hline $\begin{array}{l}\text { Quantifizierung Renilla } \\
\text { Luciferase Aktivität }\end{array}$ & & \\
\hline
\end{tabular}




\subsubsection{Bestimmung der Zellproliferation}

Um den Einfluss von HSF1 auf das Wachstumsverhalten von humanen Zellen zu bestimmen, wurde die Zellproliferation mit dem Celigo Cytometer (Nexcelom, Software Version 2.0) erfasst. Dabei wurden Zellen der Linie HCT116 verwendet, die zuvor lentiviral transduziert wurden und letztendlich HSF1 überexprimierten. Verglichen wurde dabei zwei Zelllinien, die HSF1 überexprimieren, HSF1c1 und HCT116 LentiHSF1-Klon 21 (HSF1c2), mit zwei Zelllinien, die nur das virale Kontrollkonstrukt enthielten, HCT116 LentiORFKlon 13 (ORFc1) und HCT116 LentiORF-Klon 14 (ORFc2). Die Zellen wurden für $24 \mathrm{~h}$ kultiviert und das Wachstumsverhalten dann für die folgenden vier Tage mit dem Celigo Cytometer überprüft. Die Messung wurde jeweils nach 24 h durchgeführt und das Medium wurde zuvor gewechselt, um tote, nicht adhärente Zellen zu entfernen. Mit dem Celigo Cytometer wurde die Zellkonfluenz in Prozent bezogen auf die Gesamtfläche der Kulturschale gemessen. Messungen wurden als technische Triplikate durchgeführt.

A

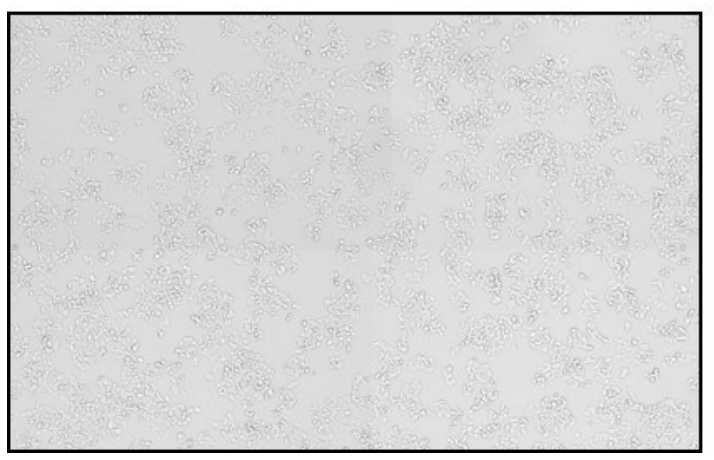

B

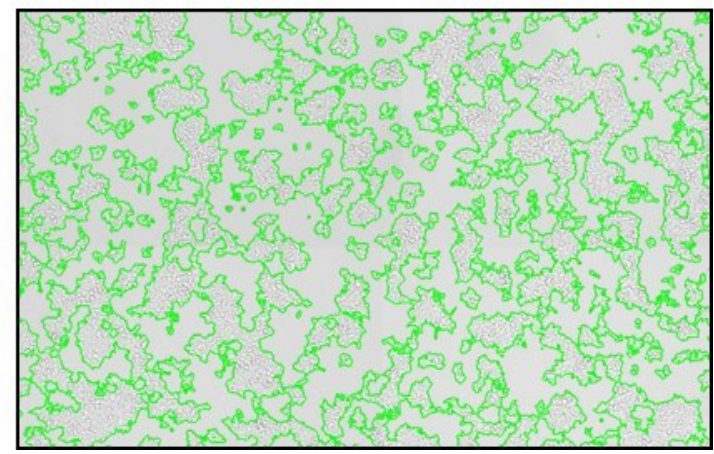

Abbildung 9: Beispielhafte Darstellung des Messprinzips zur Ermittlung der Zellkonfluenz. (A) Bild der ORFc2- Zellen nach 24 h Kultivierung. (B) Erfassung der Konfluenz (grüner Bereich) nach Einstellen der Messkriterien. 


\section{Ergebnisse}

\subsection{Eine p53-Aktivierung führt zu einer Veränderung der HSF1- Phosphorylierung}

Zur Überprüfung des Einflusses des Tumorsuppressors p53 auf HSF1 wurde in Western Blots pHSF1 untersucht. Wildtypisches p53 wurde durch den MDM2-Inhibitor Nutlin-3a indirekt durch eine Aufhebung der negativen Rückkopplungsschleife zwischen p53 und MDM2 aktiviert.

In verschiedenen Darmkrebszellen mit wildtypischem p53 führte die Aktivierung von p53 durch $20 \mu \mathrm{M}$ Nutlin-3a für $24 \mathrm{~h}$ zu einer Veränderung von pHSF1. Untersucht wurden HCT116-, RKO- sowie LS174T-Zellen. Beim Nachweis von pHSF1 im Western Blot entstanden mehrere Banden, die im Größenbereich von $85 \mathrm{kDa}$ bis $120 \mathrm{kDa}$ detektiert wurden. Nach p53-Aktivierung war der Verlust einer der oberen Banden zu beobachten (Abbildung 10).

\section{HCT116}

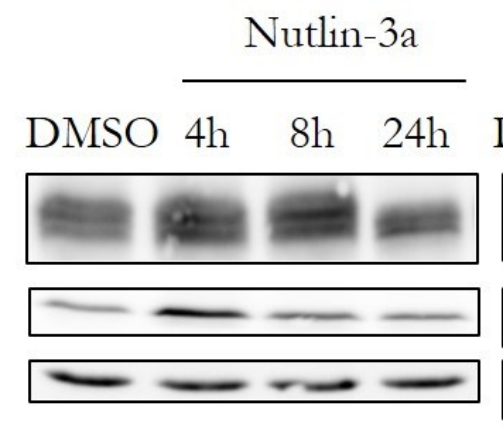

LS174T

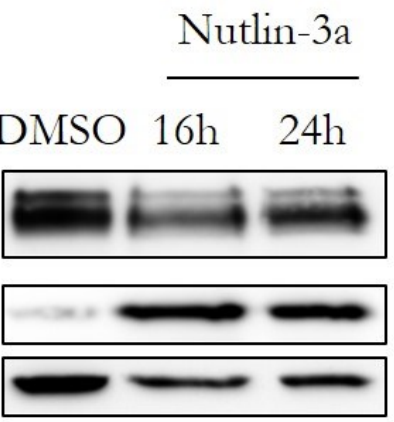

RKO

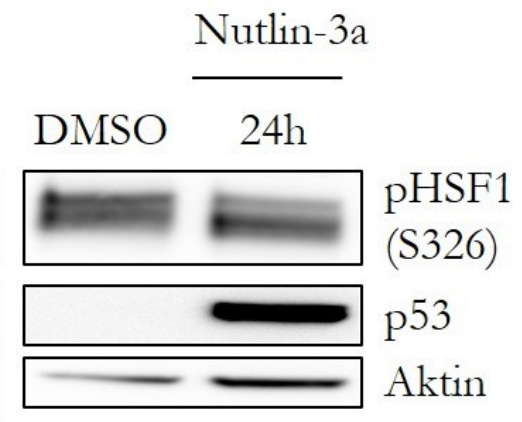

Abbildung 10: p53-Aktivierung führt zu einer Reduktion von pHSF1. Mehrere Darmkrebszelllinien mit wildtypischem p53 (HCT116, LS174T, RKO) wurden mit DMSO oder $20 \mu \mathrm{M}$ Nutlin-3a für 24 h behandelt. Repräsentative Western Blots. Unabhängige Exprimente für HCT116 $n=3, \operatorname{LS174T} n=3, \operatorname{RKO} n=2$ (biologische Replikate).

Zusätzlich wurde pHSF1 nach Zellbehandlung mit den zwei verschiedenen DNAschädigenden Pharmaka Campothecin und Doxorubicin überprüft. Eine DNA-Schädigung führte zu einer starken p53-Aktivierung. Die DNA-Schädigung führte zu einer Reduktion von pHSF1 wie die Behandlung mit Nutlin-3a, es kam zum Verlust der oberen Banden. Dieser Effekt ging ebenfalls mit p53-Akkumulation als Zeichen der p53-Aktivierung einher (Abbildung 11A).

Weiterhin sollte geklärt werden, ob die herbeigeführte Reduktion von pHSF1 abhängig vom p53-Status ist. Dazu wurden SW480-Darmkresbzellen mit mutiertem p53 mit $20 \mu \mathrm{M}$ Nutlin3a behandelt und pHSF1 bestimmt. In SW480-Zellen führte eine p53-Aktivierung mit 
Nutlin-3a nicht zu einer Veränderung des p53-Levels. Im betrachteten Zeitrahmen kam es nicht zu einer Veränderung von pHSF1 nach p53-Aktivierung (Abbildung 11B).

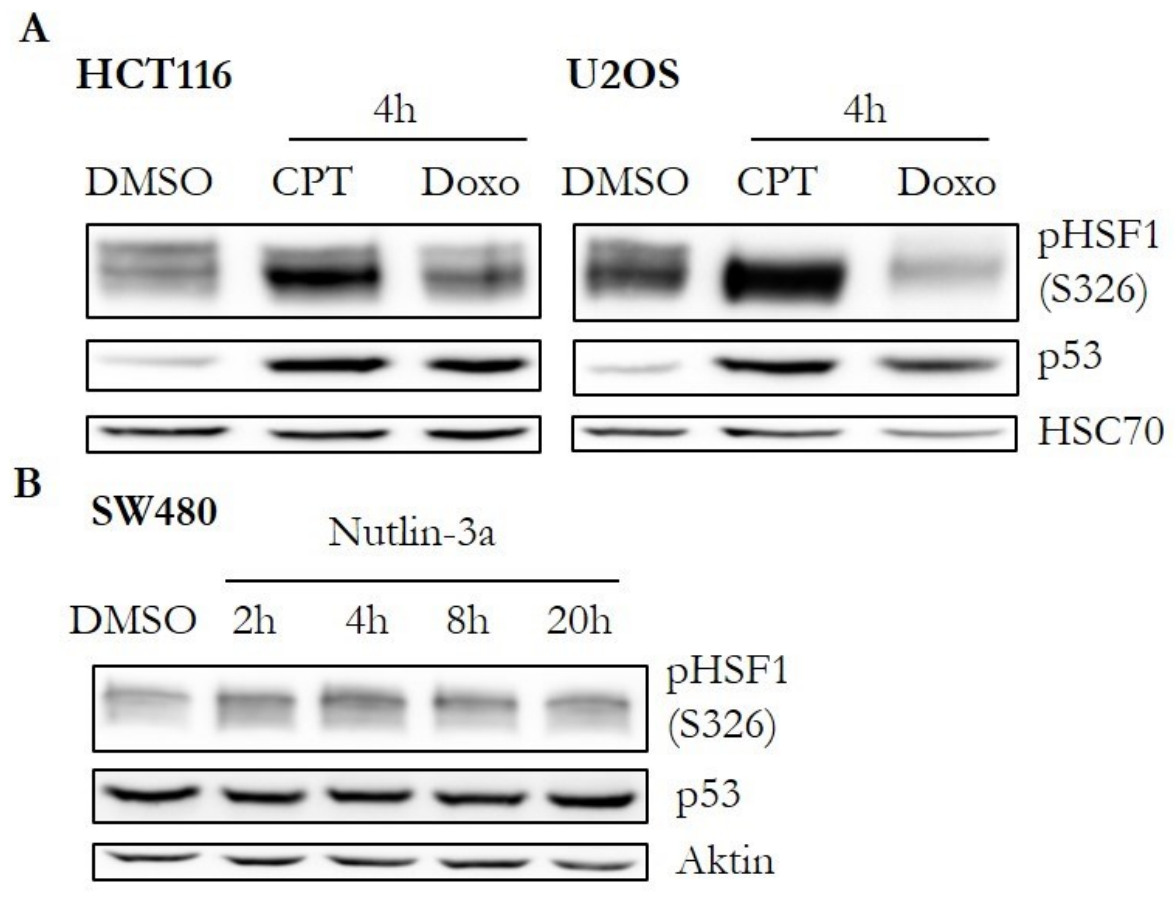

Abbildung 11: pHSF1 wird durch wildtypisches p53 reduziert. (A) Zellen wurden mit 2,87 $\mu \mathrm{M}$ Campothecin oder $500 \mathrm{nM}$ Doxorubicin für 4 h behandelt. $\mathrm{n}=1$. (B) In SW480-Zellen mit mutiertem p53 kam es nach Behandlung mit $20 \mu \mathrm{M}$ Nutlin-3a für $24 \mathrm{~h}$ nicht zu einer Reduktion von pHSF1. $\mathrm{n}=1$.

In den Versuchen zeigte sich ein p53-spezifischer, regulatorischer Effekt auf HSF1, der mit einer Reduktion von pHSF1 einherging. Dieser Effekt ist abhängig von wildtypischen, funktionellem p53. Welchen Einfluss damit p53 auf die Aktivität von HSF1 hat, kann hieraus noch nicht sicher abgeleitet werden.

\subsection{Eine p53-Aktivierung hemmt die Expression von HSF1- regulierten Genen}

Es konnte gezeigt werden, dass eine p53-Aktivierung mit einer Reduktion von pHSF1 einhergeht. Um zu klären, welchen Effekt dies auf die transkriptionelle HSF1-Aktivität hat, wurde die Expression verschiedener HSF1-regulierter Gene mittels qPCR überprüft.

Zunächst wurde verschiedene HSF1-regulierte Gene gewählt und die Expression nach knockdown von HSF1 überprüft (Abbildung 12). Ausgewählt wurden sowohl HSF1-regulierte Gene, die zu den stressinduzierten Chaperonen wie HSPA1B zählen, als auch solche, die Zellmigration wie ITGB3BP oder Zellzyklusregulation wie CDC6 regulieren. Eine HSF1Depletion verringerte stark die Expression aller betrachteten HSF1-Zielgene. Die 
Abhängigkeit der Expression der ausgewählten Gene HSPA1B, CDC6 und ITGB3BP vom Transkriptionsfaktor HSF1 konnte bestätigt werden, jedoch kam es nicht zu einer vollständigen Unterdrückung der Expression.

HCT116

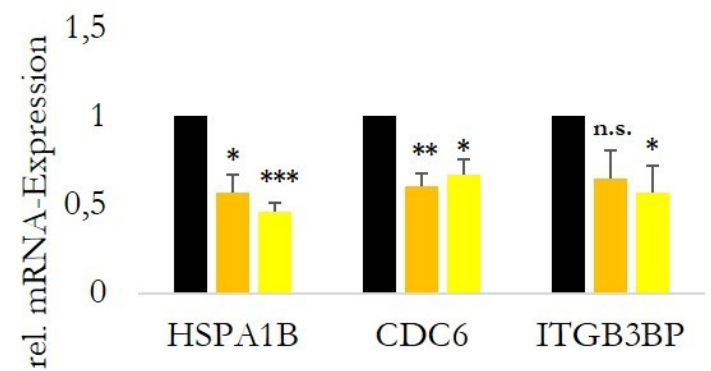

- Kontrolle $\because \mathrm{HSF} 1 \mathrm{KD} \# 1=\mathrm{HSF} 1 \mathrm{KD} \# 2$
$\mathrm{RKO}$

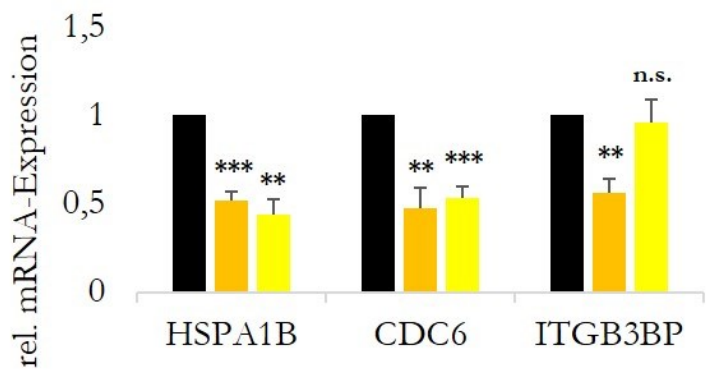

Kontrolle $₫$ HSF1 KD \#1 $=$ HSF1 KD \#2

Abbildung 12: Analyse ausgewählter HSF1-Zielgene. HCT116- und RKO-Zellen wurde mit einer Kontroll-siRNA oder mit zwei HSF1-siRNA für $72 \mathrm{~h}$ behandelt. Die mRNA-Expression von HSPA1B, CDC6 und ITGB3BP wurde mittels qPCR ermittelt. Expression standardisiert zu RPLPO. Unabhängige Experimente $\mathrm{n}=3$. Die Diagrammbalken zeigen den Mittelwert \pm Standardfehler. Student t-Test: ${ }^{*} \mathrm{p}<0,05{ }^{*} \mathrm{p}<0,01$ $* * * \mathrm{p}<0,001$ n.s. $=$ nicht signifikant. $\mathrm{KD}=$ knock-down.

Zusätzliche HSF1-Zielgene wurden für die weiteren Analysen ausgewählt. Alle HSF1Zielgene zeigten sich nach einer Zellbehandlung mit Nutlin-3a reprimiert. Für die Zielgene HSP90AA1 und HSPB1 war die Reduktion zwar nicht statistisch signifikant, aber es zeigte sich eine einheitliche Tendenz (Abbildung 13).

\section{HCT116 RKO}

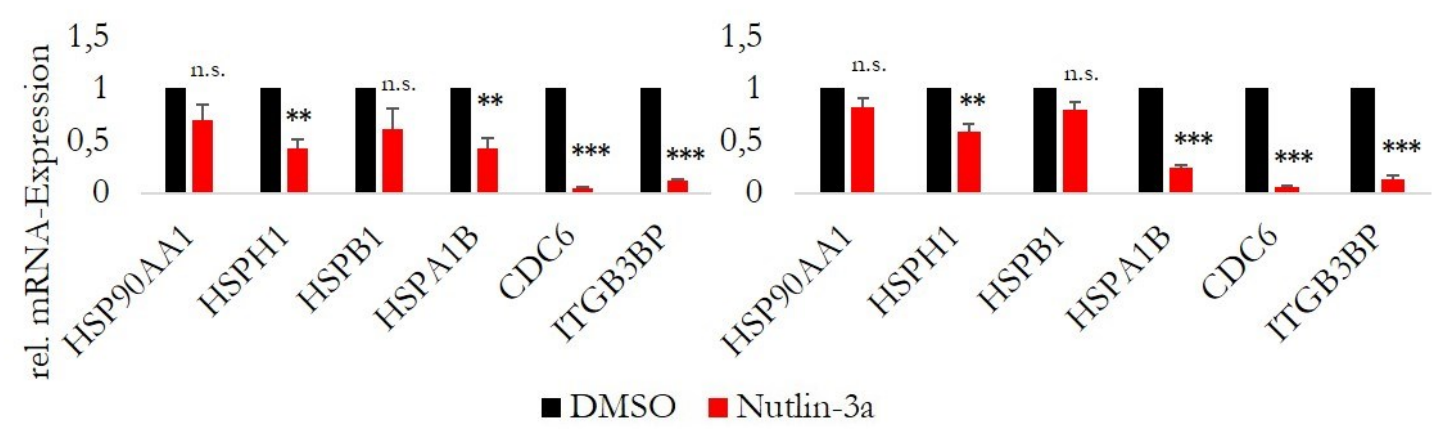

Abbildung 13: Expression von HSF1-regulierter Zielgene nach p53-Aktivierung in HCT116- und RKO-

Zellen. HCT116- und RKO-Zellen wurden mit DMSO oder $20 \mu \mathrm{M}$ Nulin-3a für $24 \mathrm{~h}$ behandelt. Expression standardisiert zu RPLO. Unabhängige Experimente $\mathrm{n}=3$. Die Diagrammbalken zeigen den Mittelwert \pm Standardfehler. Student t-Test: ${ }^{*} \mathrm{p}<0,05 * * \mathrm{p}<0,01 * * * \mathrm{p}<0,001$ n.s. $=$ nicht signifikant. 
Um einen unspezifischen Effekt von Nutlin-3a auszuschließen und die p53-abhängige HSF1-Regulation zu beweisen, wurden HCT116- und RKO-Zellen mit zwei siRNAs gegen TP53 transfiziert. Zudem wurde p53 durch Nutlin-3a in den Zellen aktiviert. Eine p53Depletion verhindert größtenteils die Nutlin-3a-vermittelte HSF1-Inhibition und bestätigt damit die p53-abhängige HSF1-Regulation (Abbildung 14).

\section{HCT116}

\section{$\begin{array}{lll}\text { HSPA1B } & \text { CDC6 }\end{array}$}
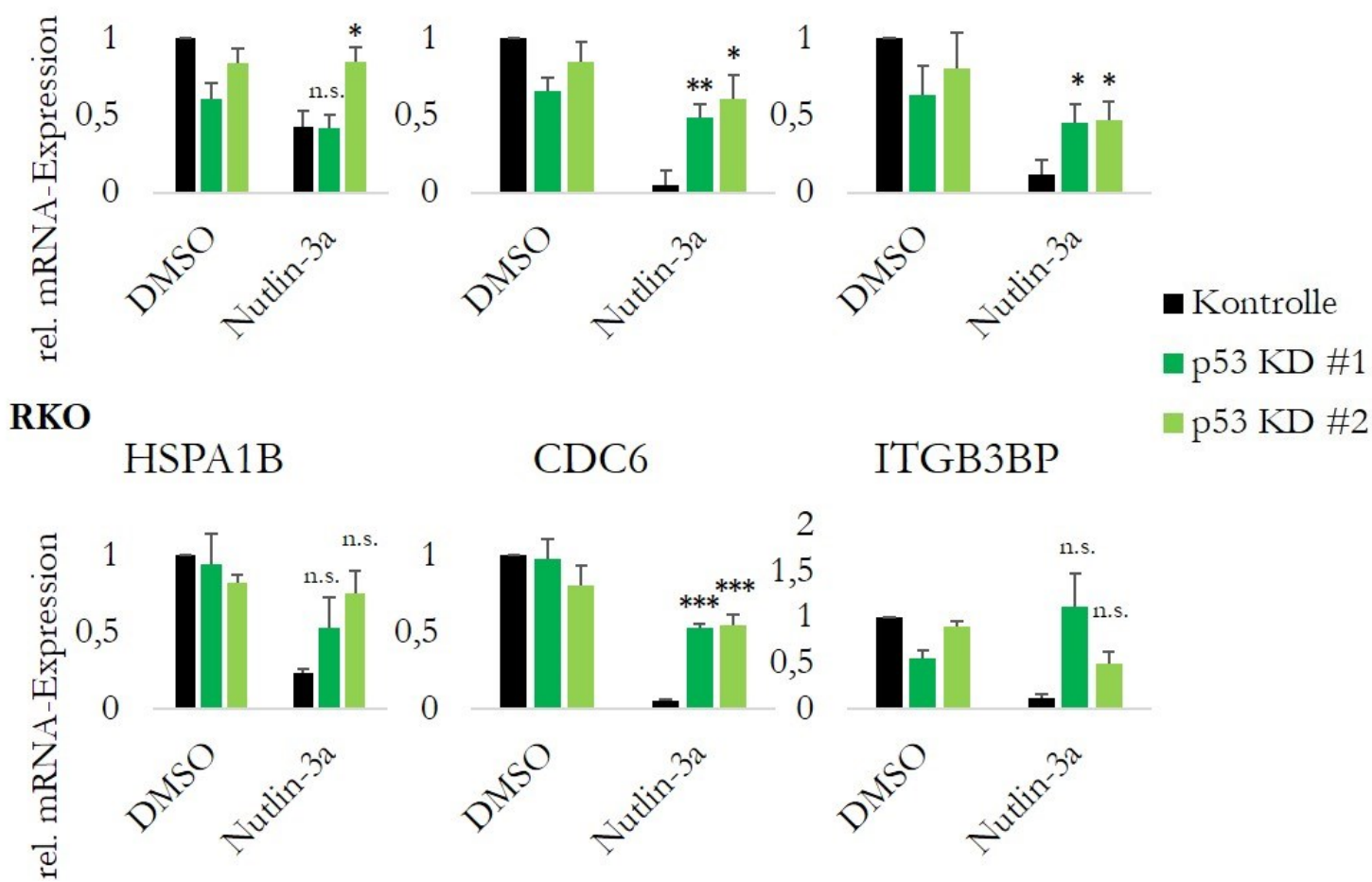

Abbildung 14: Die Nutlin-3a-vermittelte Repression von HSF1 ist abhängig von wildtypischem p53. HCT116- und RKO-Zellen wurden mit Kontrol-siRNA oder mit zwei siRNAs gegen TP53 für $72 \mathrm{~h}$ behandelt. Für die finalen $24 \mathrm{~h}$ erfolgte eine Behandlung mit $20 \mu \mathrm{M}$ Nutlin-3a. Expression standardisiert zu RPLO. Unabhängige Experimente $\mathrm{n}=3$. Diagrammbalken zeigen Mittelwert \pm Standardfehler. Student $\mathrm{t}$-Test: ${ }^{*} \mathrm{p}<0,05 * * \mathrm{p}<0,01 * * * \mathrm{p}<0,001$ n.s. $=$ nicht signifikant. $\mathrm{KD}=$ knock-down.

\subsection{Eine CDK4/6-Inhibition reduziert pHSF1}

Nachdem ein reprimierender Effekt von p53 auf HSF1 im verwendeten Modell des kolorektalen Karzinoms in vitro nachgewiesen werden konnte, sollte Klarheit über einen möglichen Signalweg gewonnen werden.

Durch Aktivierung des Transkriptionsfaktors p53 wird das Gen CDKN1A, welches für den Zellzyklusinhibitor p21 kodiert, stark induziert. Der Zellzyklusinhibitor p21 inhibiert verschiedene CDKs und stoppt somit die Zellzyklusprogression. Diese Hochregulation von CDKN1A konnte in HCT116- und RKO-Zellen bestätigt werden (Abbildung 15). 
HCT116 RKO

CDKN1A

\section{CDKN1A}

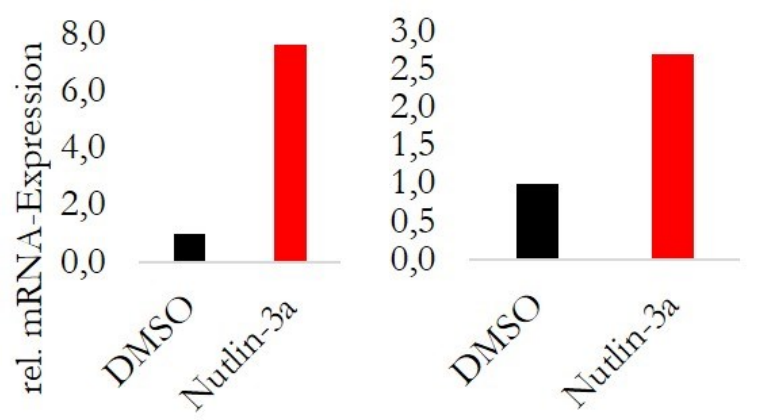

Abbildung 15: $C D K N 1 A$ wird durch p53-Aktivierung durch Nutlin-3a stark induziert. HCT116- und RKO-Zellen wurden für $24 \mathrm{~h}$ mit DMSO oder $20 \mu \mathrm{M}$ Nutlin-3a behandelt. $\mathrm{n}=1$.

Um eine Beteiligung von p21 an der p53-abhängigen HSF1-Repression nachzuweisen, wurden HCT116- und RKO-Zellen mit zwei siRNAs gegen CDKN1 $A$ transfiziert. Zudem wurde eine p53-Aktivierung durch Behandlung mit $20 \mu \mathrm{M}$ Nutlin-3a in den Zellen herbeigeführt. Eine p21-Depletion vermindert die Nutlin-3a-induzierte HSF1-Inhibition und bestätigt damit eine p53-p21-vermittelte HSF1-Inhibition (Abbildung 16). 
HCT116

HSPA1B

CDC6

ITGB3BO

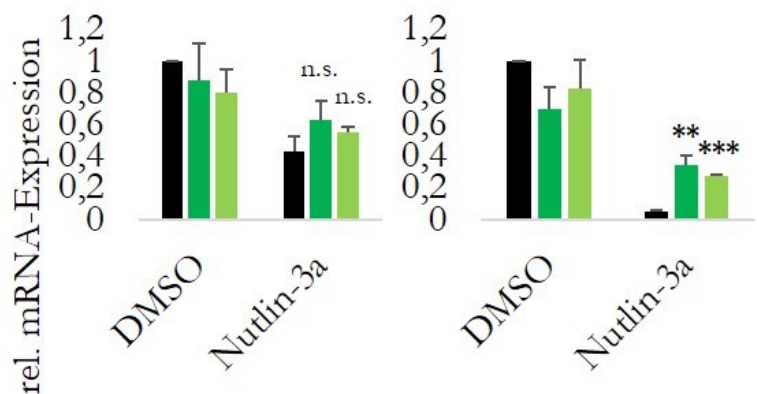

1,5

- Kontrolle

RKO

HSPA1B

CDC6

ITGB3BP

- $\mathrm{p} 21 \mathrm{KD} \# 1$
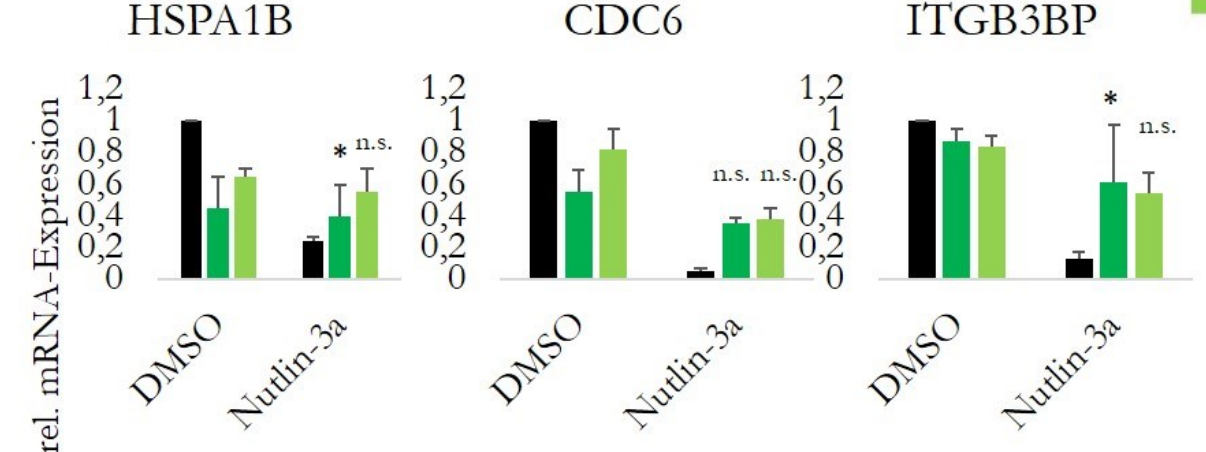

Abbildung 16: Die Nutlin-3a-vermittelte Repression von HSF1 ist abhängig von p21. HCT116- und RKO-Zellen wurden mit Kontrol-siRNA oder mit einer von zwei siRNAs gegen CDKN1 $A$ für $72 \mathrm{~h}$ behandelt. Für die finalen $24 \mathrm{~h}$ erfolgte eine Behandlung mit $20 \mu \mathrm{M}$ Nutlin-3a. Expression standardisiert zu RPLO. Unabhängige Experimente $\mathrm{n}=3$. Diagrammbalken zeigen Mittelwert \pm Standardfehler. Student $\mathrm{t}-$ Test: ${ }^{*} \mathrm{p}<$ $0,05^{* *} \mathrm{p}<0,01 * * * \mathrm{p}<0,001$ n.s. $=$ nicht signifikant.

Da CDKs durch p21 direkt gehemmt werden, stellen sie ein mögliches Bindeglied zwischen p53 und HSF1 dar. Für die weiteren Untersuchungen wurden daher zwei verschiedene Inhibitoren von CDKs (PD0332991 und RO3306) mit unterschiedlicher Spezifität ausgewählt. Zusätzlich wurde LY294002 als Inhibitor des PI3K-Signalwegs verwendet. HCT116-Zellen wurden mit den genannten Inhibitoren behandelt. Nach Abschluss der Behandlung wurden Proteinlysate erstellt und diese als Proben für einen Western Blot verwendet.

RO3306 inhibierte in hohen Konzentrationen pHSF1, was auf eine Rolle von CDK4 hindeutet. Der spezifische CDK4/6-Inhibitor PD0332991 zeigte ebenfalls eine Reduktion von pHSF1. Die Wirkung beider Inhibitoren zeigte sich vergleichbar mit Nutlin-3a. Die Behandlung mit LY294002 führte zu keiner Veränderung von pHSF1. In LS174T-Zellen, welche wildtypisches p53 exprimieren, zeigt sich die Reduktion von pHSF1 nach Behandlung mit PD0332991 (Abbildung 17). 


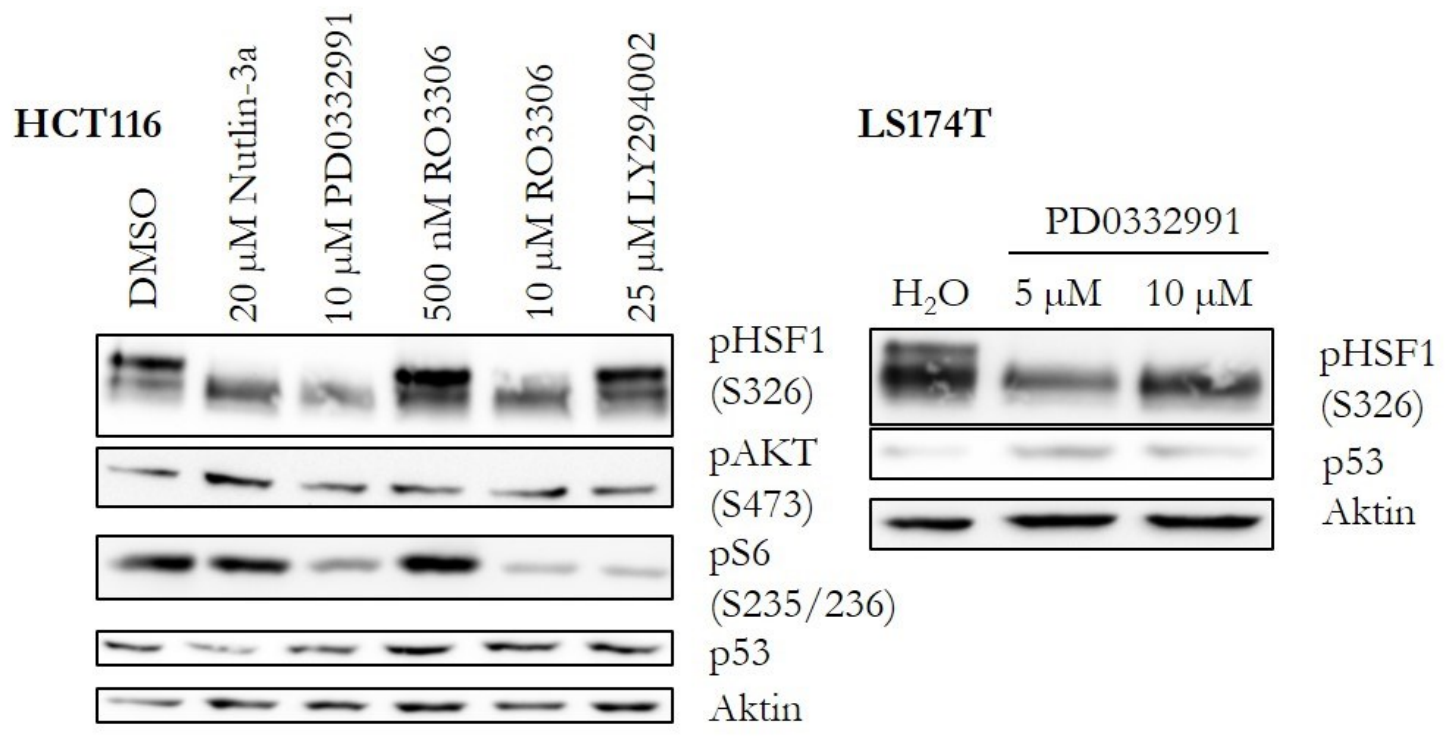

Abbildung 17: CDK4/6-Inhibition reduziert pHSF1. Zellbehandlung von HCT116-Zellen mit verschiedenen Inhibitoren in den angegebenen Konzentrationen für 24 h. n = 1. LS174T-Zellen wurden mit PD0332991 für 24 h behandelt. Unabhängige Experimente $n=2$. Repräsentative Western Blots.

Der Inhibitor PD0332991 wurde für weitere Experimente verwendet und p53-defiziente Zellen wurden behandelt. PD0332991 reduziert pHSF1 in p53-defizienten HCT116-Zellen und bestätigt somit, dass CDK4/ 6 downstream an der HSF1-Regulation beteiligt ist. HCT116Zellen, welche wildtypisches p53 exprimierten, wiesen die pHSF1-Reduktion auf und dienten als Kontrolle. Es kam dabei zu einer Veränderung des gesamten Intensitätsverhältnisses der Banden der pHSF1-Färbung. Eine Regulierung von pHSF1 wird durch die p53-p21CDK4/6-Achse vermittelt. Als funktionelle Kontrolle der CDK4/6-Inhibition wurde die Phosphorylierung von Rb gefärbt. Die Abnahme dieser Phosphorylierung bestätigt die Wirkung des CDK4/6-Inhibitors PD0332991 (Abbildung 18). 


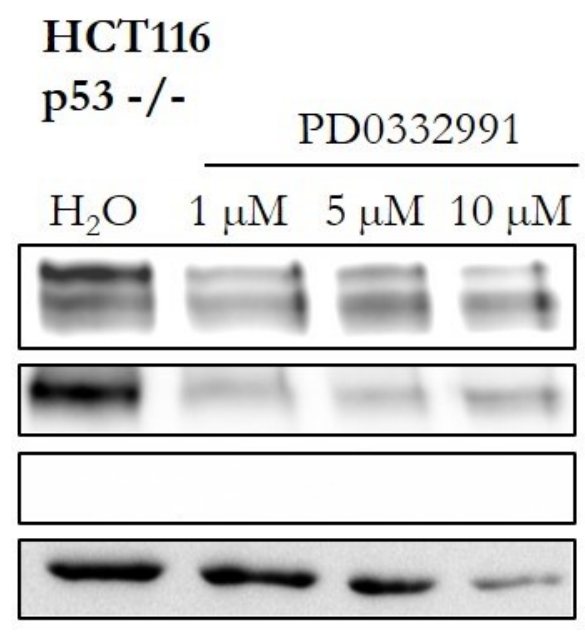

HCT116

p53 +/+ P53+/+ PD0332991

$\mathrm{H}_{2} \mathrm{O} \quad 1 \mu \mathrm{M} \quad 5 \mu \mathrm{M} \quad 10 \mu \mathrm{M}$

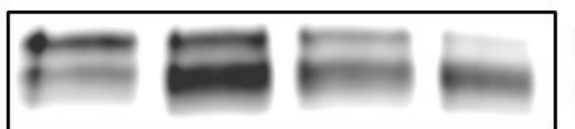

pHSF1

(S326)

$\mathrm{pRb}$

(S807/S811)

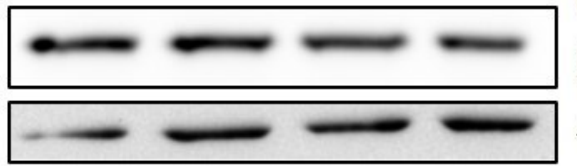

p53

Aktin

Abbildung 18: CDK4/6 vermittelt die p53-abhängige Reduktion von pHSF1. Zellen wurden mit PD0332991 in den angezeigten Konzentrationen für $24 \mathrm{~h}$ behandelt. Repräsentative Western Blots. Unabhängiger Experimente für HCT116 p53 +/+ n = 3, für HCT116 p53 -/- n = 2 .

Um den Einfluss von CDK4/6 auf HSF1 zu bestätigen, wurde ein zweiter CDK4/6Inhibitor (LEE011) ausgewählt. Zusätzlich wurde ein zweiter MDM2-Inhibitor (RG7112) überprüft. Die Behandlung mit 5 MM RG7112 zeigte den gleichen Effekt wie die Behandlung mit Nutlin-3a in den Darmkebszellen und bestätigt wildtypisches p53 als HSF1-Repressor. Demgegenüber hatte die Behandlung mit LEE011 keinen Effekt in HCT116-Zellen bzw. nur einen sehr schwachen Effekt in RKO-Zellen auf pHSF1. Die funktionelle Überprüfung der Färbung für phosphoryliertes Rb bestätigte, dass die CDK-Inhibition durch LEE011 nicht effizient funktioniert hat und damit auch keine HSF1-Reprimierung zu erwarten war (Abbildung 19). 


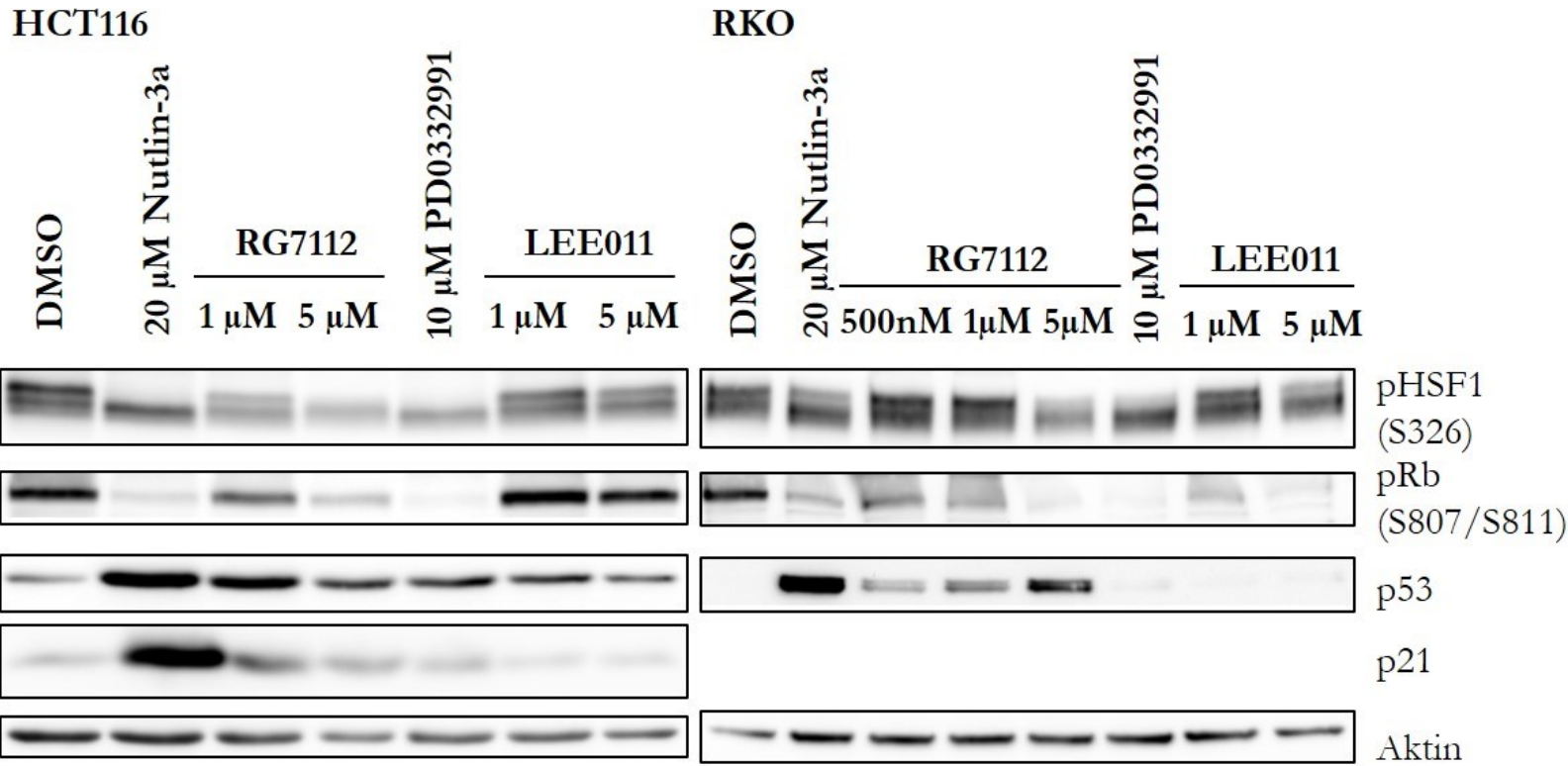

Abbildung 19: Eine p53-Aktivierung bzw. CDK4/6-Inhibition führen reproduzierbar zu einer Reduktion von pHSF1. Zellen wurden mit den angezeigten Inhibitoren in den genannten Konzentrationen für 24 h behandelt. Unabhängige Experimente $n=2$. Repräsentative Western Blots.

\subsection{Eine CDK4/6-Inhibition hemmt die Expression von HSF1- regulierten Genen}

Eine CDK4/6-Inhibition führte zu einer Reduktion von pHSF1 (Abbildung 17). Um zu klären, ob die Reduktion von pHSF1 durch CDK4/6-Inhibtion ebenfalls zu einer verminderten HSF1-Aktivität führt, wurde wiederum die Expression von HSF1-Zielgenen nach CDK4/6-Inhibition überprüft.

Die Behandlung mit dem CDK4/6-Inhibitor PD0332991 führte ebenfalls zum Rückgang der Expression von HSF1-regulierten Genen (Abbildung 20). Allerdings zeigte sich das Ergebnis weniger eindeutig als nach p53-Aktivierung. In HCT116-Zellen kam es teilweise zu einer Erhöhung der Expression von HSPA1B, HSP90AA1 und HSPB1. In RKO-Zellen zeigte sich mit Ausnahme von HSP90AA1 die Reduktion der Expression für alle betrachteten HSF1-regulierten Gene. 
HCT116

$\mathrm{RKO}$

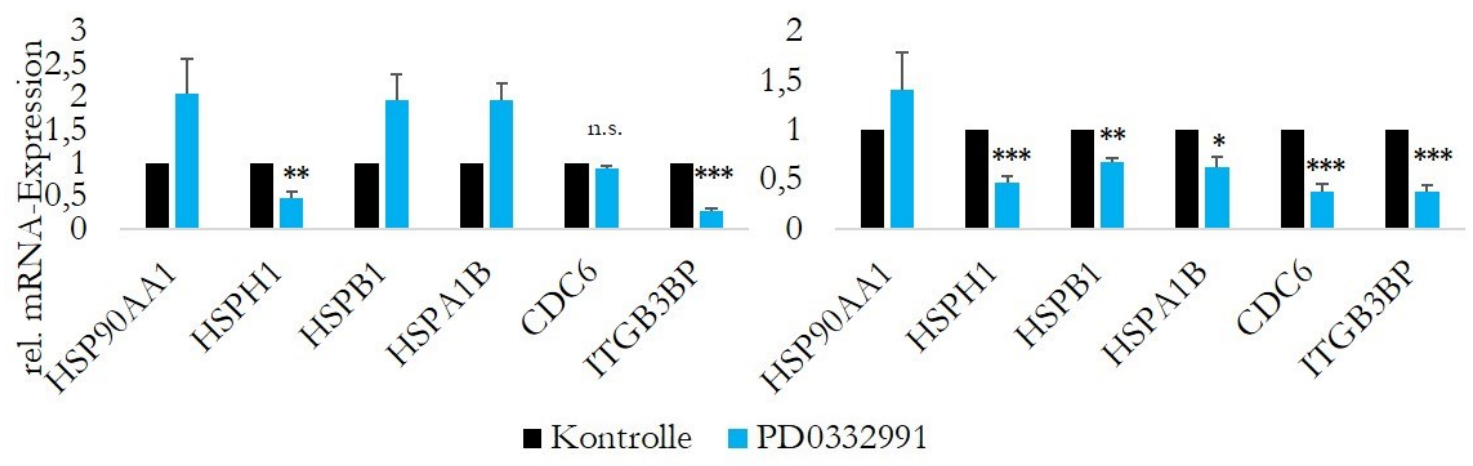

Abbildung 20: Expression von HSF1-reguliertern Zielgenen nach CDK4/6-Inhibition in HCT116- und RKO-Zellen. HCT116- und RKO-Zellen wurden mit $\mathrm{H}_{2} \mathrm{O}$ oder $10 \mu \mathrm{M}$ PD0332991 für 24 h behandelt. Expression standardisiert zu RPLO. Unabhängige Experimente $\mathrm{n}=3$. Die Diagrammbalken zeigen den Mittelwert \pm Standardfehler. Student t-Test: ${ }^{*} \mathrm{p}<0,05 * * \mathrm{p}<0,01 * * * \mathrm{p}<0,001$ n.s. $=$ nicht signifikant.

Die Ergebnisse der Expressionsanalyse von HSF1-regulierten Genen nach CDK4/6Inhibition sprechen für einen Einfluss von CDK4/6 auf die HSF1-Aktivität. Die p21vermittelte CDK4/6- Inhibition nach p53-Aktivierung führt zu einer verminderten HSF1Aktivität.

\section{5 Überprüfung der HSF1-Aktivität in einem dualen Luciferase- Assay}

Um die Wirkung einer p53-Aktivierung und CDK4/6-Inhibition auf die transkriptionelle Aktivität von HSF1 in einer zweiten Methode zu überprüfen, wurde ein dualer LuciferaseAssay durchgeführt. Dabei wurde die HSF1-regulierte Expression der Firefly-Luciferase in Relation zur konstitutiven Expression der Renilla-Luciferase gemessen.

Das verwendete Plasmid pG14.41-luc2P/HSE, welches nach Transfektion durch HSF1Bindung an HSEs zur Expression der Firefly-Luciferase führt, wurde in einem Vorversuch überprüft. In beiden Zelllinien kam es durch die Hitzeschockbehandlung zu einer starken Zunahme der relativen Luciferase-Aktivität (Abbildung 21). 


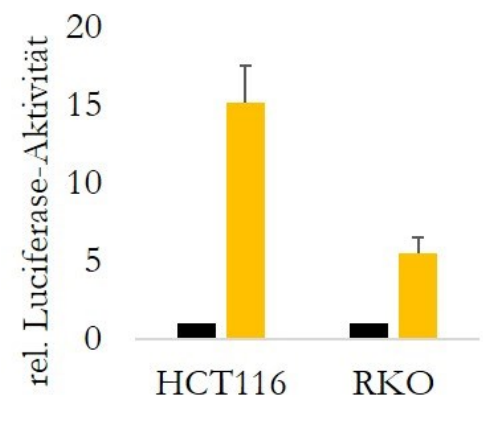

- Kontrolle $\mathrm{HS}$

Abbildung 21: Hitzeschockbehandlung führt zur Steigerung der transkriptionellen Aktivität von HSF1. HCT116- und RKO-Zellen wurden für einen dualen Luciferase-Assay verwendet. Zellen wurden für $24 \mathrm{~h}$ kultiviert. Zellen, die einer HS unterzogen wurden, sind abschließend für $1 \mathrm{~h}$ bei $42^{\circ} \mathrm{C}$ und dann für $2 \mathrm{~h}$ bei $37^{\circ} \mathrm{C}$ kultiviert worden. HS $=$ Hitzeschockbehandlung. Anzahl der unabhängigen Versuche $\mathrm{n}=3$. Diagrammbalken zeigen den Mittelwert \pm Standardfehler.

Das Plasmid pG14.41-luc2P/HSE wurde nun für weitere Versuche verwendet. Dabei wurden Zellen mit dem Inhibitor Nutlin-3a behandelt, die Expression von TP53 durch short hairpin ribonucleic acid (shRNA) mittels Transfektion mit dem Plasmid pSUPER-p53 gehemmt oder eine vermehrte Expression durch Transfektion mit dem Plasmid pcDNA-p53 erzeugt.

In HCT116- und RKO-Zellen führte eine p53-Aktivierung sowohl ohne als auch nach einer Hitzeschockbehandlung zu einer Reduktion der relativen Luciferase-Aktivität (Abbildung $22 \mathrm{~A}$, roter gegenüber schwarzem Balken). Eine p53-Depletion mittels shRNA führte hingegen jeweils zu einer Steigerung der relativen Luciferase-Aktivität (Abbildung 22A, grüner gegenüber schwarzem Balken). In HCT116-Zellen führte eine vermehrte p53Expression zu einer verminderten relativen Luciferase-Aktivität in Zellen, welche nicht einem Hitzeschock ausgesetzt wurden. Dies ließ sich in RKO-Zellen sowohl ohne als auch nach einem Hitzeschock demonstrieren (Abbildung 22A, blauer gegenüber schwarzem Balken).

In RKO-Zellen führte eine CDK4/6-Inhibition sowohl ohne als auch nach einer Hitzeschockbehandlung zu einer Reduktion der HSF1-abhängigen relativen LuciferaseAktivität (Abbildung 22B). 
A

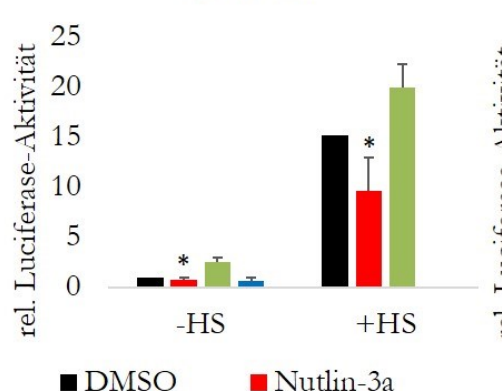

$\operatorname{shp} 53$

- pcDNA p53

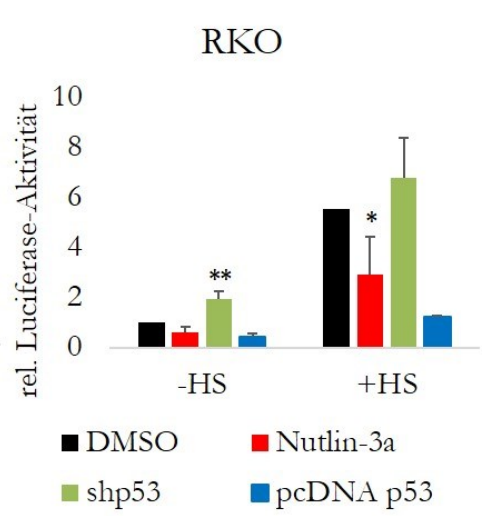

B

RKO

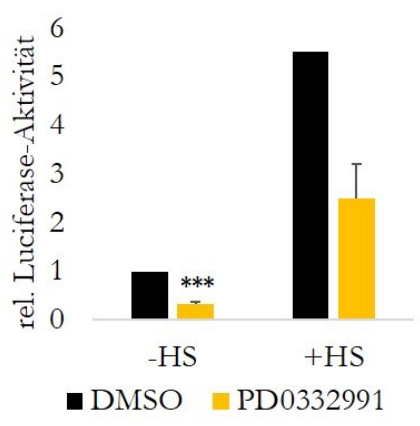

\begin{abstract}
Abbildung 22: Die HSF1-abhängige relative Luciferase-Aktivität wird durch p53 und CDK4/6 beeinflusst. (A) HCT116- bzw. RKO-Zellen wurden passagiert und für $24 \mathrm{~h}$ kultiviert. Anschließend erfolgte eine Transfektion mit $800 \mathrm{ng}$ Plasmid-DNA für $48 \mathrm{~h}$. Für die finalen $24 \mathrm{~h}$ wurden Zellen mit DMSO oder $20 \mu \mathrm{M}$ Nutlin-3a behandelt. Zellen, welche einer HS unterzogen wurden, wurden abschließend zunächst für $1 \mathrm{~h}$ bei $42^{\circ} \mathrm{C}$ und dann für $2 \mathrm{~h}$ bei $37^{\circ} \mathrm{C}$ kultiviert. (B) RKO-Zellen wurden passagiert und für $24 \mathrm{~h}$ kultiviert. Anschließend erfolgte eine Transfektion mit 800 ng Plasmid-DNA für 48 h. Für die finalen $24 \mathrm{~h}$ wurden Zellen mit $\mathrm{H}_{2} \mathrm{O}$ oder $10 \mu \mathrm{M}$ PD0332991 behandelt. Zellen, welche einer HS unterzogen wurden, wurden abschließend zunächst für $1 \mathrm{~h}$ bei $42^{\circ} \mathrm{C}$ und dann für $2 \mathrm{~h}$ bei $37^{\circ} \mathrm{C}$ kultiviert. HS = Hitzeschockbehandlung. Anzahl der unabhängigen Versuche $\mathrm{n}=3$. Diagrammbalken zeigen den Mittelwert \pm Standardfehler. Student t-test: ${ }^{*} \mathrm{p}<$ $0,05 * * \mathrm{p}<0,01 * * * \mathrm{p}<0,001$.
\end{abstract}

\title{
3.6 Die Untersuchung von HSF1-überexprimierenden HCT116- Zellen
}

Um den Einfluss von HSF1 besser zu verstehen, wurden HSF1-überexprimierende Zelllinien untersucht. Diese waren vor Beginn der Experimente in unserem Labor generiert worden, indem HCT116-Zellen mit einem lentiviralen HSF1-Konstrukt transduziert, selektioniert und einzelne Klone vervielfältigt wurden. Einzelne klonale Linien wurden per Western Blot auf ihre HSF1-Überexpression und den Effekt einer p53-Aktivierung kontrolliert. Zwei Klone HSF1c1 und HSF1c2 sowie zwei Kontrollen ORFc1 und ORFc2 wurden untersucht. Es zeigte sich eine deutliche Signalverstärkung der pHSF1 in den HSF1-überexprimierenden Zellen. Gegenüber ORFc1 zeigten die HSF1-überexprimierenden Klone mehr Banden bei der Färbung für pHSF1, was auf das Vorliegen einer Vielzahl unterschiedlich modifizierter HSF1-Fraktionen hindeutet. Die Zelllinien wurden mit Nutlin-3a behandelt und eine deutliche Abnahme von pHSF1 wurde sichtbar. Dies bestätigt erneut, dass eine p53Aktivierung auch hohe HSF1-Levels und eine starke HSF1-Aktivität hemmen kann (Abbildung 23). 


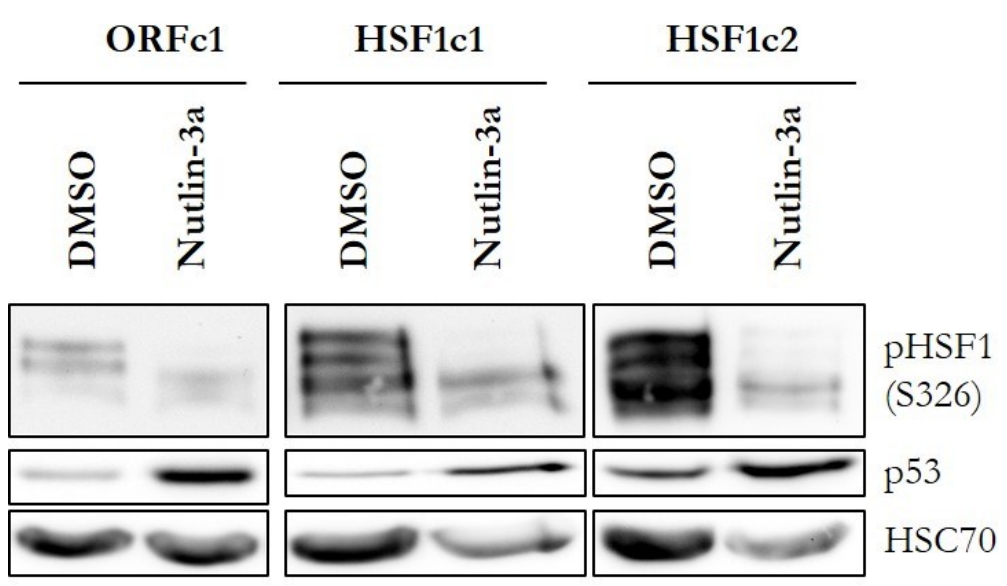

Abbildung 23: HSF1-überexprimierende Klone zeigen eine Reduktion von pHSF1 nach p53Aktivierung. ORFc1-, HSF1c1- und HSF1c2-Zellen wurden für 24 h mit DMSO oder $20 \mu \mathrm{M}$ Nutlin-3a behandelt. Repräsentative Western Blots. $\mathrm{n}=1$.

Anschließend wurde die Expression von HSF1-regulierten Genen nach p53-Aktivierung bzw. CDK4/6-Inhibition untersucht (Abbildung 24). In HSF1c1 zeigte sich eine Repression der Genexpression nach Behandlung mit Nutin-3a bzw. PD0332991. Die Ergebnisse waren mit den bisher untersuchten Zelllinien vergleichbar.

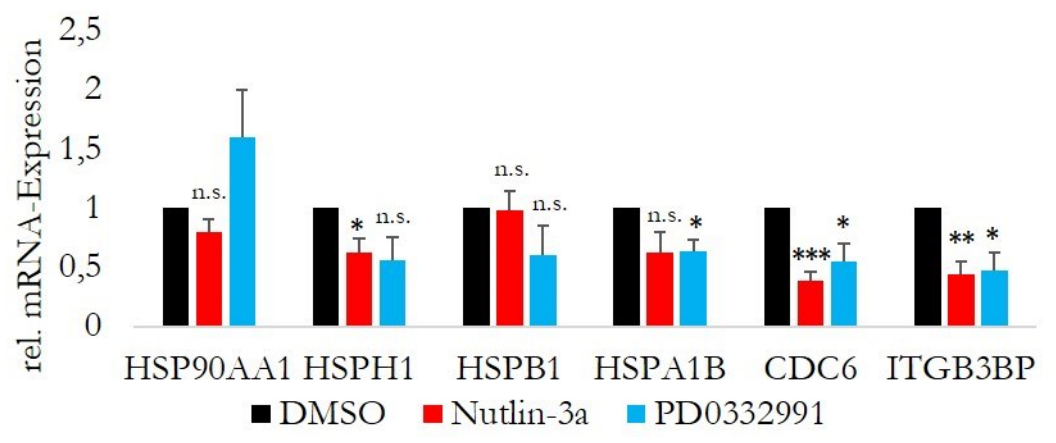

Abbildung 24: Expression HSF1-regulierter Zielgene in HSF1c1. HSF1c1-Zellen wurden für $24 \mathrm{~h}$ Stunden mit DMSO, $20 \mu \mathrm{M}$ Nutlin-3a oder $10 \mu \mathrm{M}$ PD0332991 behandelt. Expression standardisiert zu RPLO. Unabhängige Experimente $\mathrm{n}=3$. Die Diagrammbalken zeigen den Mittelwert \pm Standardfehler. Student $\mathrm{t}$ Test: ${ }^{*} \mathrm{p}<0,05 * * \mathrm{p}<0,01 * * * \mathrm{p}<0,001$ n.s. $=$ nicht signifikant.

Zudem wurde der Einfluss einer HSF1-Überexpression auf die Zellproliferation mit dem Celigo Cytometer erfasst. Alle Linien wiesen eine gleiche Proliferation über fünf Tage auf. Eine HSF1-Überexpression hatte keine proliferationsfördernde Wirkung (Abbildung 25). 
120

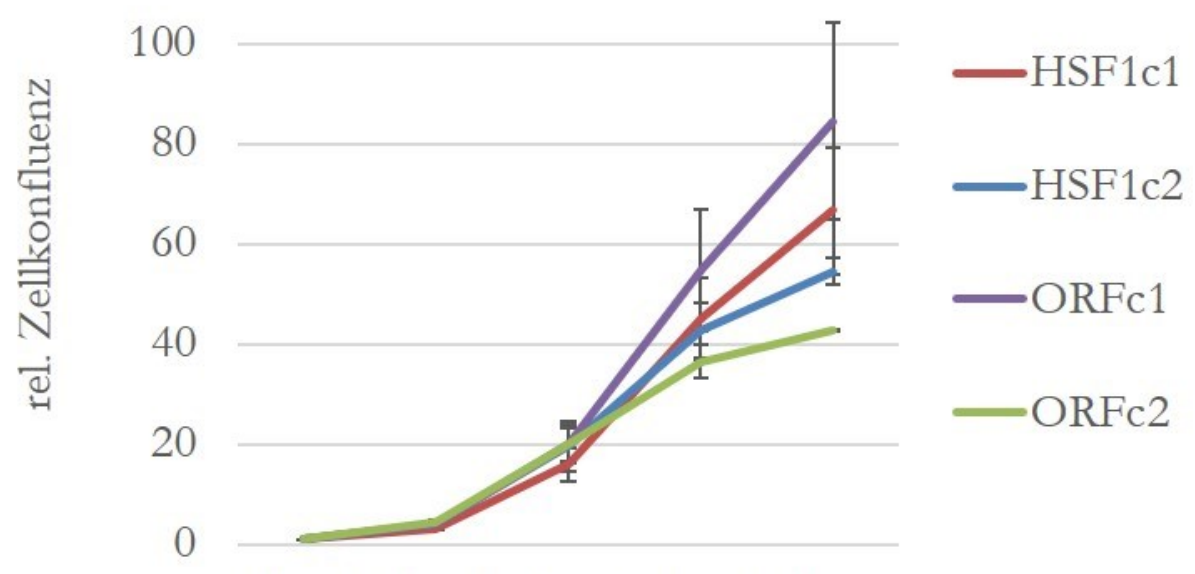

Tag 1 Tag 2 Tag 3 Tag 4 Tag 5

Abbildung 25: Eine HSF1-Überexpression hat keinen Einfluss auf die Zellproliferation. Vergleich der Zellproliferation mit dem Celigo Cytometer über fünf Tage. Die Zellkonfluenz wurde relativ zur Konfluenz am ersten Versuchstag dargestellt. HSF1c1 und HSF1c2 wurden mit ORFc1 und ORFc2 verglichen. Es zeigte sich kein Unterschied in der Proliferation. Anzahl der unabhängigen Versuche $\mathrm{n}=2$.

\subsection{Zwischen CDK4 und HSF1 findet keine Komplexbildung statt}

Zur Überprüfung, ob die posttranslationale Modifizierung von Ser326 direkt durch CDK4/6 reguliert ist, wurde eine CoIP von HSF1 oder CDK4 durchgeführt.

Für die CoIP wurden HCT116-Zellen verwendet. Zuerst wurden Zellen mit $20 \mu \mathrm{M}$ Nutlin3a für $24 \mathrm{~h}$ und für die abschließenden $6 \mathrm{~h}$ der Behandlung zusätzlich mit $10 \mu \mathrm{M}$ MG132 behandelt, um eine verbesserte Nachweisbarkeit von transienten Bindungen zu erreichen. Anschließend wurden die Zellen lysiert und eine CoIP durchgeführt. Als Primärantikörper wurde der für pHSF1-spezifische Antikörper verwendet bzw. ein CDK4-spezifischer Antikörper, als Kontrolle diente ein HA-Tag-Antikörper.

Es war eine Reduktion von pHSF1 nach Behandlung mit Nutlin-3a verglichen mit der DMSO-behandelten Kontrolle im Input sichtbar. Es zeigte sich eine starke Präzipitation von pHSF1. Beim spezifischen Nachweis von CDK4 zeigte sich ein starkes Signal im geschätzten Größenbereich von $30 \mathrm{kDa}$ im Input sowie in der CDK4-CoIP. Allerdings wurde keine CDK4-HSF1-Bindung sichtbar. Weder nach Präzipitation von pHSF1 noch nach CDK4Präzipitation zeigten sich die entsprechenden Banden auf der richtigen, angenommenen Höhe (Abbildung 26). 


\section{HCT116}

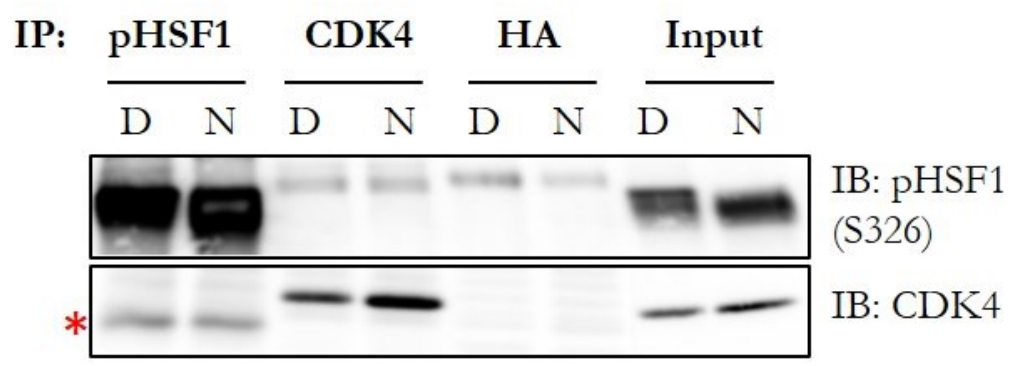

Abbildung 26: Eine Bindung von CDK4 und HSF1 ist nicht nachweisbar. HCT116-Zellen wurden für $24 \mathrm{~h}$ mit DMSO oder $20 \mu \mathrm{M}$ Nutlin-3a und für die abschließenden 6 h zusätzlich mit $10 \mu \mathrm{M}$ MG132 behandelt. Für die CoIP wurden ein für pHSF1-, CDK4- oder HA-Tag-Antikörper verwendet. D = DMSO, N $=20 \mu \mathrm{M}$ Nutlin-3a. Die mit * markierten Banden entspricht der leichten Immunglobulin-Kette.

Die CoIP wurde mehrmals mit geringfügig modifizierten Konditionen wiederholt. Es ließ sich keine Komplexbildung von CDK4 und HSF1 nachweisen. Ebenso wurde die CoIP mit HSF1c1 wiederholt, auch hierbei zeigte sich keine Bindung zwischen CDK4 und HSF1.

\subsection{Das Interaktom von HSF1}

Eine direkte Interaktion von CDK4 und HSF1 konnte mithilfe der CoIP nicht nachgewiesen werden. Um die Beziehung zwischen p53, CDK4 sowie HSF1 besser zu verstehen, wurde versucht das Interaktom von HSF1 zu ermitteln.

Dazu wurden bereits zuvor benutzte HSF1c1-Zellen verwendet. Wie in Kapitel 2.2.4 beschrieben, wurden die Zellen zuvor in drei Populationen geteilt und mit je einem SILACKonditionierungsmedium behandelt. Nach Abschluss des Konditionierungsprozesses wurden die Zellpopulationen, welche mit den Konditionierungsmedia light bzw. medium kultiviert wurden, für $24 \mathrm{~h}$ mit DMSO behandelt, die Zellpopulation, welche mit dem Konditionierungsmedium heavy kultiviert wurde, wurde mit $20 \mu \mathrm{M}$ Nutlin-3a behandelt. Die doppelte DMSO-Behandlung war notwendig, um spezifische Interaktionspartner von HSF1 später massenspektrometrisch identifizieren zu können und auch Veränderungen durch die Behandlung mit Nutlin-3a zu registrieren. Zur Überprüfung des Behandlungserfolges wurde zuvor ein Western Blot der Proteinproben durchgeführt. Es zeigte sich die Reduktion von pHSF1 nach Behandlung mit Nutlin-3a (Abbildung 27). 
DMSO Nutlin-3a

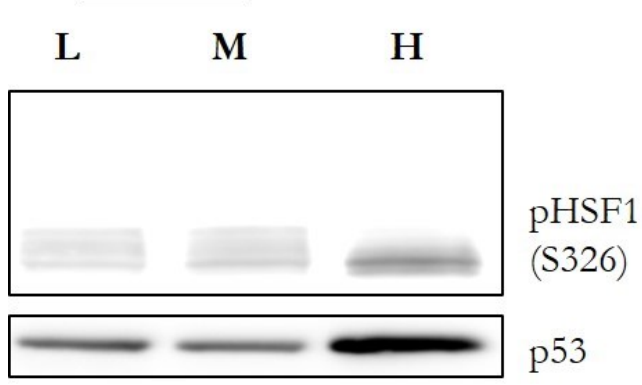

Abbildung 27: Überprüfung der Behandlung mit Nutlin-3a vor massenspektrometrischer Analyse des HSF1 Interaktoms. HSF1c1-Zellen wurden für $24 \mathrm{~h}$ mit DMSO oder $20 \mu \mathrm{M}$ Nutlin-3a behandelt. Die Behandlung mit Nutlin-3a zeigte den bekannten Effekt auf die Phosphorylierung von HSF1. L = light. M = medium. $\mathrm{H}=$ heavy.

Der Versuch wurde zusätzlich in einem zweiten Ansatz unter Verwendung von PD0332991 zur Behandlung der mit dem Konditionierungsmedium heavy kultivierten Zellpopulation durchgeführt, sodass in beiden Ansätzen jeweils die Populationen light bzw. medium mit DMSO und die Population heavy mit Nutlin-3a bzw. PD0332991 behandelt wurden.

Anschließend wurde mehrere CoIPs für die Proben durchgeführt. Als Primärantikörper wurde ein für total HSF1-spezifischer Antikörper verwendet. In einem Vorversuch wurde dieser im Vergleich zum bisher verwendeten, pHSF1-spezifischen Antikörper getestet. Bei der Färbung für pHSF1 zeigte sich eine vermehrte Anzahl von Banden durch Verwendung des total HSF1-Antikörpers zur CoIP (Abbildung 28). Aufgrund der höheren Effizienz bei der CoIP wurde der total HSF1-spezifische Antikörper weiterverwendet, um möglichst viele unterschiedlich modifizierte HSF1-Fraktionen für die massenspektrometrische Analyse zu präzipitieren.

\section{HSF1c1}

\section{IP: pHSF1 HSF1 Input}

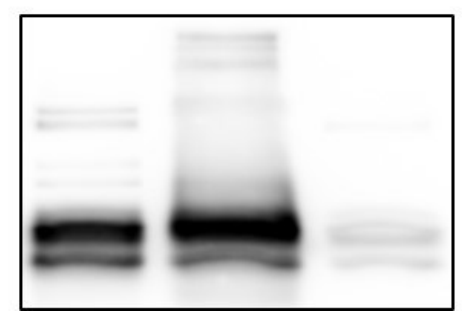

pHSF1

(S326)

Abbildung 28: Vergleich zweiter Antikörper zur CoIP. HSF1c1-Zellen wurden für 24 h mit DMSO behandelt. Anschließend wurde die CoIP angeschlossen.

Als Kontrollantikörper wurde in beiden Ansätzen ein für den HA-Tag-spezifischer Antikörper verwendet. Eine Übersicht über den Ablauf der Zellkultivierung und - 
behandlung sowie die Spezifität der verwendeten Primärantikörper wird in Tabelle 24 dargestellt.

Tabelle 24: Überblick über vorbereitende Schritte für die CoIPs zur massenspektrometrischen Analyse.

\begin{tabular}{|l|l|l|l|}
\hline CoIP-Ansatz & Kultivierungsmedium & Zellbehandlung & Primärantikörper \\
\hline \multirow{4}{*}{1} & light & DMSO & HA-Tag \\
\cline { 2 - 4 } & medium & DMSO & HSF1 \\
\cline { 2 - 4 } & heavy & Nutlin-3a & HSF1 \\
\hline \multirow{2}{*}{2} & light & DMSO & HA-Tag \\
\cline { 2 - 5 } & medium & DMSO & HSF1 \\
\cline { 2 - 5 } & heavy & PD0332991 & HSF1 \\
\hline
\end{tabular}

Die entstandenen Proben wurden gepoolt und bei $-80^{\circ} \mathrm{C}$ gelagert. Ebenso wurde ein Aliquot der verwendeten Zellen eingefroren und eingelagert.

Alle Proben wurden zur massenspektrometrischen Analyse $\mathrm{zu}$ unseren Kooperationspartnern in der Arbeitsgruppe von Dr. Petra Beli (Institute of Molecular Biology in Mainz) gesendet. Dort erfolgte die massenspektrometrische Auswertung der Proben sowie die statistische Analyse der Ergebnisse.

Es konnten zahlreiche Interaktionspartner von HSF1 identifiziert werden (Abbildung 29). Aufgrund der zuvor erfolgten SILAC-Behandlung der verschiedenen Zellpopulationen in zwei Ansätzen sowie der unterschiedlichen Behandlung der Zellen in beiden Ansätzen mit Nutlin-3a bzw. PD0332991 war eine vergleichende Analyse der Interaktionspartner von HSF1 zwischen verschiedenen Behandlungsmodalitäten möglich. Abbildung 29 zeigt im Allgemeinen Interaktionspartner von HSF1 im rechten oberen Quadranten, welche verglichen mit dem Kontrollantikörper in beiden Versuchen eine spezifische Bindung an HSF1 aufwiesen. Als cut-off wurde für beide Ansätze eine Anreicherung um den Faktor 2 in der CoIP gegenüber der Kontrolle gewählt. 


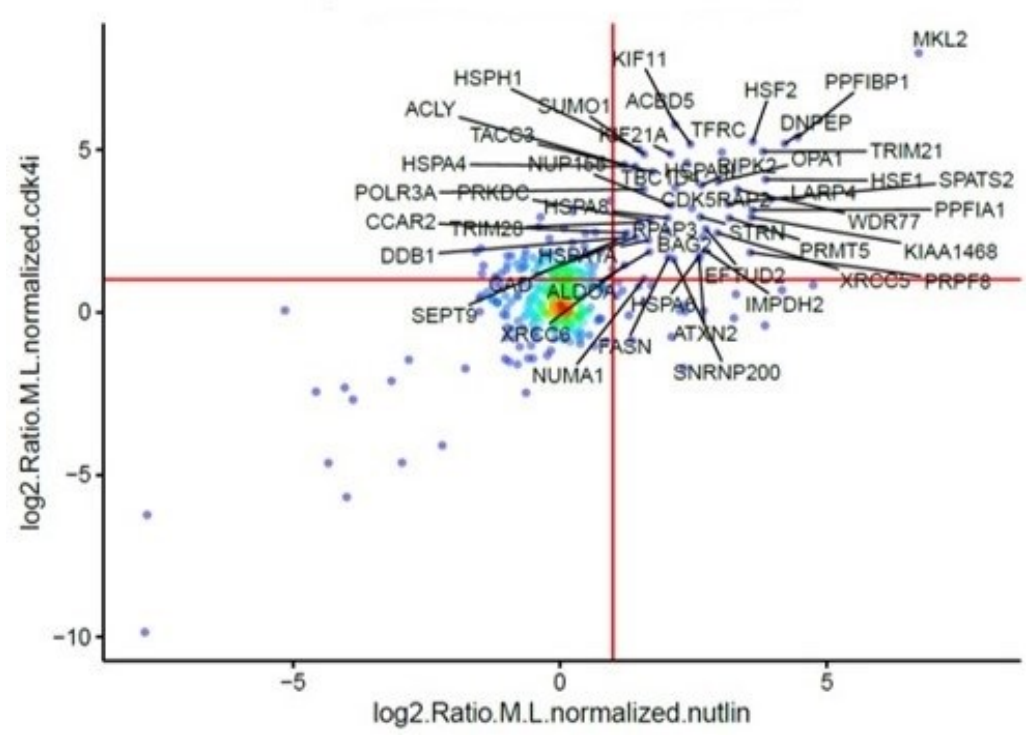

Abbildung 29: Darstellung des spezifischen HSF1-Interaktoms. Exemplarisch sind dabei Interaktionspartner dargestellt, die in beiden Ansätzen eine spezifische Bindung an HSF1 gegenüber der Kontrolle zeigten. Analyse und Darstellung erstellt durch Matthias Ostermeier, Institute of Molecular Biology, Mainz.

Anschließend wurde der Einfluss einer p53-Aktivierung bzw. CDK4/6-Inhibition auf die Bindung des HSF1-Interaktoms untersucht (Abbildung 30). Eine vermehrte Bindung durch p53-Aktivierung würde sich hier als Linksverschiebung darstellen. Eine vermehrte Bindung durch CDK4/6-Inhibition würde sich als Verschiebung nach oben darstellen. Von den identifizierten Bindungspartnern kam es nur für sehr wenige zu einer Regulierung durch die Zellbehandlung. 


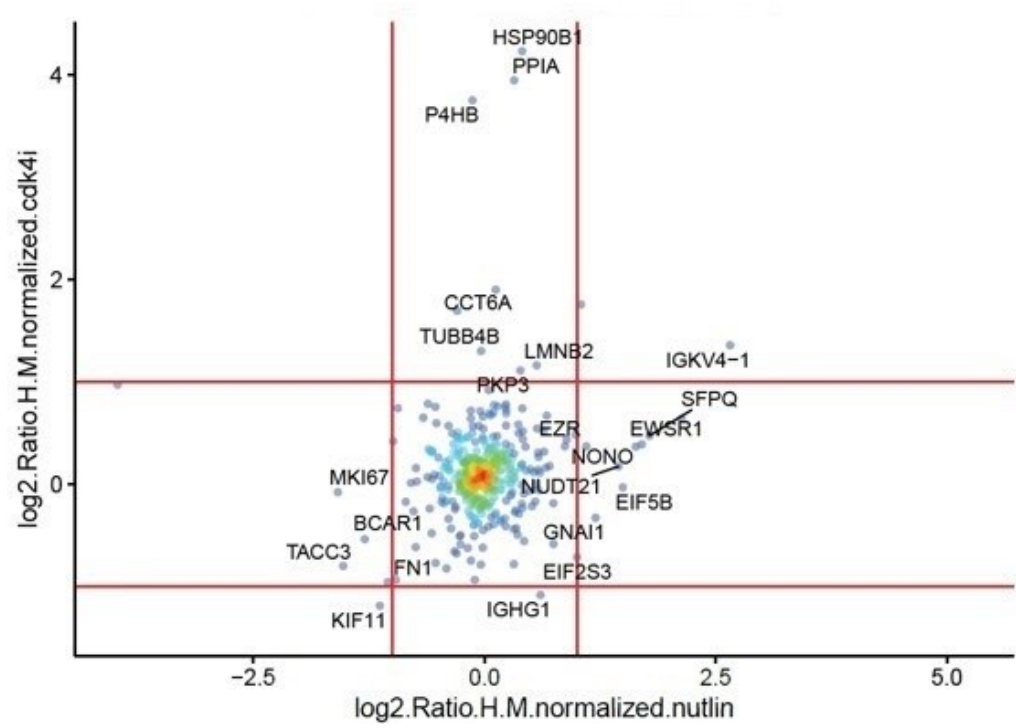

Abbildung 30: Darstellung des HSF1-Interaktoms nach Zellbehandlung. Dargestellt sind exemplarisch Interaktionspartner von HSF1 in Abhängigkeit der Zellbehandlung mit $20 \mu \mathrm{M}$ Nulin-3a bzw. $10 \mu \mathrm{M}$ PD0332991 für 24 h. Analyse und Darstellung erstellt durch Matthias Ostermeier, Institute of Molecular Biology, Mainz.

Die Validierung interessanter Bindungspartner soll in Zukunft erfolgen. Eine Regulation der Bindungsintensität nach p53-Aktivierung oder CDK4/6-Inhibition an HSF1 konnte nicht nachgewiesen werden. 


\section{Diskussion}

Ziel dieser Arbeit war es zu ermitteln, ob der Tumorsuppressor p53 einen regulierenden Einfluss auf den Transkriptionsfaktor HSF1 im Modell des kolorektalen Karzinoms ausübt. HSF1 hat starken Einfluss auf die Tumorentstehung und Progression, was bereits in verschiedenen Modellsystemen etabliert werden konnte (Dai et al. 2007; Santagata et al. 2011; Scott et al. 2011; Fang et al. 2012). An der Regulierung von HSF1 sind unterschiedliche Mechanismen beteiligt darunter auch ein komplexes Zusammenspiel verschiedener posttranslationaler Modifizierungen. Insbesondere der aktivierende Einfluss von pHSF1 auf die HSF1-Aktivität ist bekannt und konnte in malignen Zellen vermehrt nachgewiesen werden (Guettouche et al. 2005; Mendillo et al. 2012). Daher wurde als Maß der HSF1Aktivierung der Status dieser Modifizierung sowie die Expression HSF1-regulierter Gene untersucht.

Erstmals wurde in dieser Arbeit ein regulierender Einfluss des Tumorsuppressors p53 auf die Aktivität von HSF1 gezeigt. Dabei ging eine Aktivierung von wildtypischem p53 mit einer Reduktion von pHSF1 einher. Zudem zeigte sich eine verminderte Expression von HSF1regulierten Genen. Dies ist abhängig von p21 und CDK4/6. p53 übt somit einen spezifischen, regulatorisch inhibitorischen Effekt auf HSF1 aus. Die direkte Regulation von HSF1 durch CDK4/6 wurde jedoch experimentell ausgeschlossen.

\subsection{Identifizierung möglicher HSF1-Regulatoren}

pHSF1 wurde mittels spezifischer Antikörper im Western Blot untersucht. Dabei zeigten sich mehrere Banden bei der Färbung, von denen einige nach p53-Aktivierung in ihrer Intensivität abnahmen (Abbildung 10). Hierbei handelt es sich um mehrere HSF1Fraktionen, welche aufgrund verschiedener Modifizierungen zwar unterschiedliche Laufeigenschaften in der Gelelektrophorese aufzeigen, jedoch alle nachweislich durch Bindung des Antikörpers pHSF1 enthielten. Eine HSF1-Überexpression zeigte bei der Färbung für pHSF1 weitere Banden, die bei normaler Expression nicht detektierbar waren. Dies legt das Modell einer komplexen Regulierung von HSF1 durch verschiedene posttranslationale Modifizierungen nahe (Abbildung 8, Abbildung 23).

Nach p53-Aktivierung tritt ein Verlust einiger, oberer Banden der pHSF1-Färbung auf, wofür ein Verlust von pHSF1 in einer dieser HSF1-Fraktionen oder eine Veränderung anderer Modifizierungen als mögliche Ursache dienen könnten. In Zellen, welche mutiertes p53 exprimieren, ließ sich der beschriebene Effekt nicht nachweisen. Es kam in SW480Zellen nach Behandlung mit Nutlin-3a zu keiner Veränderung von pHSF1 (Abbildung 11B). Der regulatorische Effekt ist auf wildtypisches p53 beschränkt und geht mit dem Auftreten von p53-Mutationen verloren.

Verschiedene Kinasen sind an der Regulierung von pHSF1 beteiligt (Chou et al. 2012; Schulz et al. 2014; Tang et al. 2015). Hierfür sind bereits der Einfluss des MAPK- sowie des PI3K- 
Signalwegs beschrieben. Der Einfluss des PI3K-Signalwegs konnte in dieser Arbeit nicht nachgewiesen werden. Die pharmakologische Inhibition des PI3K-Signalwegs führte zu keiner Verminderung von pHSF1 (Abbildung 17). Allerdings muss hierbei das jeweils verwendete Zellmodell bedacht werden. Im Falle von Schulz (2014) wurde mit HER2positiven Brustkrebszellen gearbeitet. Eine HER2-Amplifizierung rekrutiert massiv den PI3K-Signalweg zur Zellerhaltung und führt hierüber zu einer HSF1-Überaktivierung. Es erscheint daher logisch, dass in diesem Zellmodell eine Inhibition des PI3K-Signalwegs zu einer HSF1-Inaktivierung führt (Schulz et al. 2014). Im Modell des kolorektalen Karzinoms ist der PI3K-Signalweg jedoch kein Hauptsignalweg der Zellerhaltung und auch nicht an der Regulierung von HSF1 beteiligt.

Der Einfluss des MAPK-Signalwegs wurde in dieser Arbeit nicht weiter überprüft, jedoch scheint der Mechanismus der HSF1-Regulierung über den MAPK-Signalweg durchaus interessant. Während MEK Ser326 direkt phosphoryliert, wird dies durch Phosphorylierung von Ser307 unterdrückt, sodass sich hieraus ein differenzierter Rückkopplungskreis ergibt. An dieser Inhibition ist ERK beteiligt, welche Ser307 phosphoryliert (Tang et al. 2015). Die Beteiligung des MAPK-Signalwegs an der Regulierung von HSF1 im Modell des kolorektalen Karzinoms stellt eine interessante Fragestellung dar.

Aufgrund der Vielzahl von Phosphorylierungen von HSF1 wurde das HSF1-Interaktom untersucht. Hierbei konnte ein Einblick in Interaktionspartner und modifizierende Kinasen von HSF1 gewonnen werden (Anckar und Sistonen 2011). Zahlreiche Interaktionspartner konnten identifiziert werden (Abbildung 29). Diese müssen in Zukunft validiert und ihr Einfluss untersucht werden. Weiterhin muss der Aktivitätsstatus von neu identifizierten Interaktionspartner geklärt werden. Bei der Überprüfung des HSF1-Interaktoms in Abhängigkeit einer p53-Aktivierung oder CDK4/6-Inhibition zeigten sich die meisten Bindungspartner in der Intensität der Bindung unverändert (Abbildung 30). Eine Regulierung des Aktivitätszustandes der Interaktionspartner statt der Intensität der Bindung an HSF1 kann dies erklären. Auch die mögliche Beteiligung weiterer Phosphorylierungen neben pHSF1 an der Regulierung von HSF1 durch den Tumorsuppressor p53 erfordert weitere Untersuchungen.

Neben Phosphorylierungen als Mediatoren der transkriptionellen Aktivität von HSF1 ist der Einfluss weiterer posttranslationaler Modifizierungen beschrieben. Abhängig von der Phosphorylierung von Ser303 kann es zu einer Sumoylation von HSF1 kommen (Hietakangas et al. 2003). Diese Proteinmodifizierung mit small ubiquitin-like modifier (SUMO) nimmt inhibitorischen Einfluss auf die transkriptionelle Aktivität von HSF1 (Hietakangas et al. 2006). Besonders interessant ist dies, da durch die kovalente Bindung von SUMO eine starke Veränderung des Laufverhaltens von HSF1 in der Gelelektrophorese zu erwarten ist.

Auch der Einfluss von Acetylierungen auf die HSF1-Aktivität ist beschrieben. Acetylierungen haben inhibitorischen Einfluss auf die transkriptionelle HSF1-Aktivität, jedoch besteht dieser Effekt insbesondere im Zusammenhang mit der zellulären 
Stressreaktion nach Hitzeschock. Eine Hemmung der Deacetylase Sirtuin 1 vermittelt eine verminderte Stressantwort und Expression von HSPs (Westerheide et al. 2009). Inwieweit ein solcher Mechanismus auf die Aktivität in malignen Zellen übertragen werden kann, welche nicht einem zusätzlichen Hitzeschock ausgesetzt wurden, bleibt fraglich.

Prinzipiell bestätigte sich bei der Untersuchung HSF1-überexprimierende Zellen, dass die tumorfördernde Wirkung von HSF1 nicht quantitativ von der HSF1-Expression abhängt, sondern vielmehr durch den Status der HSF1-Modifizierung. Eine alleinige HSF1Überexpression führte zu keiner Steigerung der Zellproliferation (Abbildung 25).

Eine p21-vermittelte Inhibition von CDK4/6 führte zur Reduktion von pHSF1 (Abbildung 17). Allerdings zeigte sich bei der Überprüfung des Einflusses einer CDK4/6-Inhibition diskrepante Ergebnisse (Abbildung 20). Gerade für HSP90AA1 erhöhte sich die Expression nach Behandlung mit PD0332991. Wodurch dieser Effekt auf die transkriptionelle Aktivität von HSF1 durch CDK4/6-Inhibition zustande kam, konnte nicht abschließend geklärt werden. Allerdings reguliert p53 viele Signalwege, von denen CDK4/6 nur einer ist. Daher sind weitere Signalwege neben CDKs für die Regulierung von HSF1 durch p53 denkbar. Dennoch wurde die Mehrzahl der ausgewählten HSF1-Zielgene nach CDK4/6-Inhibition deutlich reprimiert. Eine Komplexbildung von CDK4 und HSF1 wurde jedoch ausgeschlossen (Abbildung 26), obwohl eine proteomweite in silico Analyse möglicher Substrate von CDK4 HSF1 als Substrat identifizieren konnte (Anders et al. 2011). Daher scheint CDK4 nicht direkt HSF1 im Modell des kolorektalen Karzinoms zu modifizieren. Eine Interaktion von CDK6 und HSF1 wurde nicht überprüft.

Aufbauend auf diese Ergebnisse ist daher die Untersuchung der Rb-E2F-vermittelten G1-SPhasen-Transition interessant. Durch Phosphorylierung von Rb tragen CDK4/6 zur Freisetzung des Transkriptionsfaktors E2F aus dem Komplex mit Rb bei (Malumbres und Barbacid 2001). Dies ermöglicht die E2F-abhängige Expression von Genen, welche entscheidend an der Zellzyklusprogression sowie an weitere zelluläre Prozesse wie Mitose, DNA-Reparatur und auch Apoptose beteiligt sind (Polager und Ginsberg 2008) Unter den E2F-Zielgenen befinden sich eine Vielzahl von Kinasen und Phosphatasen z.B. CDK1, CDK2 oder PLK1, die HSF1 modifizieren könnten (Bracken et al. 2004).

\subsection{Der Einfluss von wildtypischem p53 auf das tumorfördernde HSF1-System}

HSF1 ist an der Regulierung der Chaperone-Aktivität, der Zellmigration und -proliferation beteiligt (Mendillo et al. 2012). Die Expression der untersuchten Gene zeigte sich nach p53Aktivierung vermindert (Abbildung 13). Im dualen Luciferase-Assay bestätigte sich ein inhibitorischer Effekt von p53 auf die HSF1-Aktivität (Abbildung 22). Die vermehrte Expression von p53 führte zu einer Minderung der relativen Luciferase-Aktivität, während eine p53-Depletion den gegenteiligen Effekt zeigte. HSF1 wird also durch p53 in seiner 
tumorfördernden Wirkung konstitutiv inhibiert. Die HSF1-regulierte Stressantwort wird zudem durch die p53-vermittelte Stressantwort gegenreguliert. Dabei scheint die p53vermittelte Stressantwort einen dominanten Effekt gegenüber einem Stress, wie z. B. Hitzeschock, zu haben (Abbildung 22). Dies zeigt deutlich, dass p53 einen Stressmodulator für Tumorzellen darstellt und verdeutlicht den Selektionsdruck für Tumorzellen, den Tumorsuppressor p53 auszuschalten (Mantovani et al. 2019).

Dies zeigt sich durch den Verlust von wildtypischen p53 beim Übergang vom kolorektalen Adenom zum Karzinom (Baker et al. 1990). Die in dieser Arbeit in vitro gewonnen Ergebnisse legen nahe, dass der Tumorsuppressor p53 das HSF1-System wie ein Schrittmacher begrenzen kann. Tumorzellen, welche wildtypisches p53 exprimieren, sind nicht vollumfänglich in der Lage tumorfördernde, HSF1-regulierte Gene zu exprimieren, wenn sie Zellstress durch die Behandlung mit Nutlin-3a ausgesetzt sind. Beim Verlust von wildtypischen p53 kommt es dann zum Wegfall dieser inhibitorischen Wirkung. Für Tumorzellen besteht eine Notwendigkeit die HSF1-Aktivität durch Eliminierung von p53 zu entgrenzen. Dies erklärt den vollständigen Verlust von p53, der sich in aggressiven Karzinomen zeigt (Alexandrova et al. 2017).

Die in diesem Zusammenhang bereits von mehreren Autoren geäußerte Vermutung, dass Kenntnisse über den p53-Status von soliden Tumoren für eine gerichtete molekulare Therapie genutzt werden könnten, kann durch Aufklärung der p53-vermittelten HSF1Inhibition um einen weiteren Aspekt ergänzt werden. Dabei ist nach Verlust von p53 eine HSF1-HSP90-abhängige vermehrte Stabilisierung von Tumorproteinen anzunehmen, welche durch den Einsatz von HSP90-Inhibitoren pharmakologisch gezielt inhibiert werden kann.

Interessanterweise wird mutiertes p53 selbst durch HSP90 stabilisiert (Li et al. 2011) Die HSP90-vermittelte Proteinstabilisierung von mutiertem p53 im Tiermodell des kolorektalen Karzinoms geht mit einer höheren Anzahl größerer sowie invasiver Tumore einher (SchulzHeddergott et al. 2018). Durch HSP90-Inhibition oder -Depletion kann die Proteinstabilisierung von Tumorproteinen beseitigt werden (Li et al. 2011). Daraus ergibt sich, dass eine Mutation von TP53 eine HSF1-Überaktivierung und HSP-Expression zusätzlich ermöglicht. Wenn es sich bei der Mutation von TP53 um eine Missense-Mutation handelt, kann HSP90 zusätzlich das mutierte p53 stabilisieren und zum gain-of-function beitragen. Hierdurch kommt es gleichzeitig zum Verlust von wildtypischem p53 und der Stabilisierung von mutiertem p53.

\subsection{Ausblick}

Eine regulatorische Verbindung zwischen p53 und HSF1 wurde nachgewiesen. Dabei hat wildtypisches p53 inhibitorische Wirkung auf die HSF1-Aktivität. Weiterhin wurde der Einfluss von p21 und CDK4/6 identifiziert, wobei eine Komplexbildung aus CDK4 und 
HSF1 ausgeschlossen wurde. Wie p53 Einfluss auf HSF1 nimmt, konnte nicht genau geklärt werden. Hierfür sind weitere Experimente notwendig. Aufgrund der überragenden Rolle von posttranslationalen Modifizierungen bei der Regulierung von HSF1 stellt die Identifizierung von p53-regulierten Modifizierungen eine der Hauptaufgaben dar. Außerdem bleibt der Einfluss downstream der p53-p21-CDK4/6-Achse gelegener Mediatoren offen.

Zusätzlich kann auch der Einfluss von HSF1 bei der Behandlung von Patienten eine Rolle spielen. Die Therapie des kolorektalen Karzinoms umfasst verschiedene Therapiesäulen. Von besonderer Bedeutung ist das chirurgische Vorgehen im Rahmen einer nach onkologischen Grundsätzen durchgeführten Resektion (Heald 1988; Hohenberger et al. 2009). Darüber hinaus unterliegt die systemische, medikamentöse Chemotherapie einer beständigen Weiterentwicklung und ist entscheidend für die Prognose (Abrams et al. 2014). Um den Einfluss von HSF1 auf die therapeutische Wirkung von DNA-schädigenden Chemotherapeutika besser zu verstehen, sollte die HSF1-Aktivität nach DNA-Schädigung untersucht werden. Sollte sich hierbei ein Einfluss von DNA-schädigenden Chemotherapeutika auf das HSF1-System bestätigen, könnte nachfolgend der Einfluss einer CDK4/6-Inhibition auf die therapeutische Wirkung untersucht werden. 


\section{$5 \quad$ Zusammenfassung}

Ziel dieser Arbeit war es, den Einfluss des Tumorsuppressors p53 auf den Transkriptionsfaktor heat-shock factor 1 (HSF1) zu ermitteln. HSF1 reguliert das Stressinduzierte Chaperone-System, von welchem Tumorzellen in ihrer Entwicklung stark abhängen. In kolorektalen Karzinomzelllinien konnte eine Regulation der posttranslationalen Modifizierung des Transkriptionsfaktors HSF1 durch Aktivierung des Tumorsuppressors p53 gezeigt werden. Es kam zu einer Reduktion der aktivierenden Phosphorylierung des Serinrests an Position 326 des HSF1. Im Western Blot zeigte sich ein komplexes Bandenmuster beim Nachweis der Phosphorylierung des Serinrests an Position 326 des HSF1, was auf eine insgesamt komplexe Regulierung des HSF1 hinweist.

Die Reduktion der Phosphorylierung des Serinrests an Position 326 des HSF1 durch p53Aktivierung hatte einen negativen Effekt auf die Aktivität des HSF1. Eine verminderte Expression von verschiedenen Zielgenen konnte nachgewiesen werden. Ebenso ließ sich dies in einem dualen Luciferase-Assay reproduzieren, wobei p53 auch die zelluläre Stressreaktion nach Hitzeschock inhibierte.

Die p53-vermittelte Regulierung des HSF1 zeigte sich abhängig vom Zellzyklusinhibitor p21. Nach p53-Aktivierung führt die Expression von p21 zu einer Inhibition von Cyclinabhängigen Kinasen. Die Inhibition der Cyclin-abhängigen Kinase 4 und 6 verursachte eine ähnliche Reduktion der Phosphorylierung des Serinrests an der Position 326 des HSF1 wie p53-Aktivierung. Der Einfluss der Inhibition der Cyclin-abhängigen Kinasen 4 und 6 auf die Aktivität des HSF1 wurde wie der Einfluss von p53 zuvor überprüft. Die Inhibition der Cyclin-abhängigen Kinasen 4 und 6 führte wie eine p53-Aktivierung zu einer Inhibition der Aktivität des HSF1 und einer verminderten Expression regulierter Zielgene.

Eine direkte Interaktion zwischen der Cyclin-abhängigen Kinase 4 und dem HSF1 wurde mittels Ko-Immunpräzipitation ausgeschlossen. Um Klarheit über den Zusammenhang von p53, dem HSF1 und den Cyclin-abhängigen Kinasen 4 und 6 zu erhalten und einen eventuellen Signalweg $\mathrm{zu}$ identifizieren, wurden vorbereitende Versuche zur Massenspektrometrie durchgeführt. Hierfür wurden HSF1-überexprimierende Zellen nach dem Verfahren des stable isotope labeling by amino acids in cell culture konditioniert und verschiedene Ko-Immunpräzipitationen durchgeführt. Massenspektrometrisch konnten zahlreiche Interaktionspartner des HSF1 identifiziert werden.

Bei der Untersuchung von HSF1-überexprimierenden Zellen zeigte sich der Einfluss von p53 auf den HSF1 erhalten. 


\section{$6 \quad$ Literaturverzeichnis}

Abrams TA, Meyer G, Schrag D, Meyerhardt JA, Moloney J, Fuchs CS (2014): Chemotherapy usage patterns in a US-wide cohort of patients with metastatic colorectal cancer. J Natl Cancer Inst 106, djt371

Alexandrova EM, Yallowitz AR, Li D, Xu S, Schulz R, Proia DA, Lozano G, Dobbelstein M, Moll UM (2015): Improving survival by exploiting tumour dependence on stabilized mutant p53 for treatment. Nature $\underline{523}, 352-356$

Alexandrova EM, Mirza SA, Xu S, Schulz-Heddergott R, Marchenko ND, Moll UM (2017): p53 lossof-heterozygosity is a necessary prerequisite for mutant p53 stabilization and gain-offunction in vivo. Cell Death Dis $\underline{8}$, e2661

Amend SR, Pienta KJ (2015): Ecology meets cancer biology: the cancer swamp promotes the lethal cancer phenotype. Oncotarget $\underline{6}, 9669-9678$

Anckar J, Sistonen L (2011): Regulation of HSF1 function in the heat stress response: implications in aging and disease. Annu Rev Biochem $\underline{80}, 1089-1115$

Anders L, Ke N, Hydbring P, Choi YJ, Widlund HR, Chick JM, Zhai H, Vidal M, Gygi SP, Braun P, Sicinski P (2011): A systematic screen for CDK4/6 substrates links FOXM1 phosphorylation to senescence suppression in cancer cells. Cancer Cell 20, 620-634

Baker SJ, Preisinger AC, Jessup JM, Paraskeva C, Markowitz S, Willson JK, Hamilton S, Vogelstein B (1990): p53 gene mutations occur in combination with 17p allelic deletions as late events in colorectal tumorigenesis. Cancer Res $\underline{50}, 7717-7722$

Boyd SD, Tsai KY, Jacks T (2000): An intact HDM2 RING-finger domain is required for nuclear exclusion of p53. Nat Cell Biol $\underline{2}, 563-568$

Bracken AP, Ciro M, Cocito A, Helin K (2004): E2F target genes: unraveling the biology. Trends Biochem Sci 29, 409-417

Brierley JD, Gospodarowicz MK, Wittekind C (Hrsg.): Digestive system tumours. In: TNM Classification of Malignant Tumours, 8. Auflage. John Wiley \& Sons, Ltd., Oxford 2017, 55104

Calderwood SK, Gong J (2016): Heat shock proteins promote cancer: It's a protection racket. Trends Biochem Sci $\underline{41}, 311-323$

Chou SD, Prince T, Gong J, Calderwood SK (2012): mTOR is essential for the proteotoxic stress response, HSF1 activation and heat shock protein synthesis. PloS One ㄱ, e39679

Christophorou MA, Ringshausen I, Finch AJ, Swigart LB, Evan GI (2006): The pathological response to DNA damage does not contribute to p53-mediated tumour suppression. Nature $\underline{443}, 214$ 217

Clevers H, Nusse R (2012): Wnt/ $\beta$-catenin signaling and disease. Cell $\underline{149}$, 1192-1205

Cunningham D, Humblet Y, Siena S, Khayat D, Bleiberg H, Santoro A, Bets D, Mueser M, Harstrick A, Verslype C et al. (2004): Cetuximab monotherapy and cetuximab plus irinotecan in irinotecan-refractory metastatic colorectal cancer. N Engl J Med $\underline{351}, 337-345$

Dai C, Whitesell L, Rogers AB, Lindquist S (2007): Heat shock factor 1 is a powerful multifaceted modifier of carcinogenesis. Cell $\underline{130}, 1005-1018$ 
Dai C, Santagata S, Tang Z, Shi J, Cao J, Kwon H, Bronson RT, Whitesell L, Lindquist S (2012): Loss of tumor suppressor NF1 activates HSF1 to promote carcinogenesis. J Clin Invest 122, 3742-3754

Donehower LA, Harvey M, Slagle BL, McArthur MJ, Montgomery CA, Butel JS, Bradley A (1992): Mice deficient for p53 are developmentally normal but susceptible to spontaneous tumours. Nature $\underline{356}, 215-221$

Eaden JA, Abrams KR, Mayberry JF (2001): The risk of colorectal cancer in ulcerative colitis: a metaanalysis. Gut $\underline{48}, 526-535$

el-Deiry WS, Tokino T, Velculescu VE, Levy DB, Parsons R, Trent JM, Lin D, Mercer WE, Kinzler KW, Vogelstein B (1993): WAF1, a potential mediator of p53 tumor suppression. Cell $\underline{75}$, $817-825$

Fang F, Chang R, Yang L (2012): Heat shock factor 1 promotes invasion and metastasis of hepatocellular carcinoma in vitro and in vivo. Cancer $\underline{118}, 1782-1794$

Fang S, Jensen JP, Ludwig RL, Vousden KH, Weissman AM (2000): Mdm2 is a RING fingerdependent ubiquitin protein ligase for itself and p53. J Biol Chem $\underline{275}, 8945-8951$

Fearon ER (2011): Molecular genetics of colorectal cancer. Annu Rev Pathol $\underline{6}$, 479-507

Feng L, Hong S, Gao J, Li J (2019): Whole-exome sequencing characterized the landscape of somatic mutations and pathways in colorectal cancer liver metastasis. J Oncol 2019, 2684075

Finn RS, Dering J, Conklin D, Kalous O, Cohen DJ, Desai AJ, Ginther C, Atefi M, Chen I, Fowst C et al. (2009): PD 0332991, a selective cyclin D kinase 4/6 inhibitor, preferentially inhibits proliferation of luminal estrogen receptor-positive human breast cancer cell lines in vitro. Breast Cancer Res BCR 11, R77

Gharbi SI, Zvelebil MJ, Shuttleworth SJ, Hancox T, Saghir N, Timms JF, Waterfield MD (2007): Exploring the specificity of the PI3K family inhibitor LY294002. Biochem J 404, 15-21

Giannakis M, Mu XJ, Shukla SA, Qian ZR, Cohen O, Nishihara R, Bahl S, Cao Y, Amin-Mansour A, Yamauchi $M$ et al. (2016): Genomic correlates of immune-cell infiltrates in colorectal carcinoma. Cell Rep 15, 857-865

Guettouche T, Boellmann F, Lane WS, Voellmy R (2005): Analysis of phosphorylation of human heat shock factor 1 in cells experiencing a stress. BMC Biochem $\underline{6}, 4$

Hahn JS, Hu Z, Thiele DJ, Iyer VR (2004): Genome-wide analysis of the biology of stress responses through heat shock transcription factor. Mol Cell Biol 24, 5249-5256

Hanel W, Marchenko N, Xu S, Yu SX, Weng W, Moll U (2013): Two hot spot mutant p53 mouse models display differential gain of function in tumorigenesis. Cell Death Differ 20, 898-909

Harper JW, Adami GR, Wei N, Keyomarsi K, Elledge SJ (1993): The p21 Cdk-interacting protein Cip1 is a potent inhibitor of G1 cyclin-dependent kinases. Cell $\underline{75}, 805-816$

Heald RJ (1988): The „Holy Plane“ of rectal surgery. J R Soc Med 1, 503-508

Hietakangas V, Ahlskog JK, Jakobsson AM, Hellesuo M, Sahlberg NM, Holmberg CI, Mikhailov A, Palvimo JJ, Pirkkala L, Sistonen L (2003): Phosphorylation of serine 303 is a prerequisite for the stress-inducible SUMO modification of heat shock factor 1. Mol Cell Biol 23, 2953-2968 
Hietakangas V, Anckar J, Blomster HA, Fujimoto M, Palvimo JJ, Nakai A, Sistonen L (2006): PDSM, a motif for phosphorylation-dependent SUMO modification. Proc Natl Acad Sci U S A $\underline{103}$, $45-50$

Hinkal G, Parikh N, Donehower LA (2009): Timed somatic deletion of p53 in mice reveals ageassociated differences in tumor progression. PloS One $\underline{4}$, e6654

Hohenberger W, Weber K, Matzel K, Papadopoulos T, Merkel S (2009): Standardized surgery for colonic cancer: complete mesocolic excision and central ligation--technical notes and outcome. Colorectal Dis Off J Assoc Coloproctology G B Irel 11, 354-364

Hong TS, Clark JW, Haigis KM (2012): Cancers of the colon and rectum: Identical or fraternal twins? Cancer Discov $2,117-121$

Hu Y, Gaedcke J, Emons G, Beissbarth T, Grade M, Jo P, Yeager M, Chanock SJ, Wolff H, Camps $\mathrm{J}$ et al. (2018): Colorectal cancer susceptibility loci as predictive markers of rectal cancer prognosis after surgery. Genes Chromosomes Cancer 푸, 140-149

Hurwitz H, Fehrenbacher L, Novotny W, Cartwright T, Hainsworth J, Heim W, Berlin J, Baron A, Griffing S, Holmgren E et al. (2004): Bevacizumab plus irinotecan, fluorouracil, and leucovorin for metastatic colorectal cancer. N Engl J Med $\underline{350}$, 2335-2342

Imperiale TF, Wagner DR, Lin CY, Larkin GN, Rogge JD, Ransohoff DF (2002): Results of screening colonoscopy among persons 40 to 49 years of age. N Engl J Med $\underline{346}, 1781-1785$

Jasperson KW, Tuohy TM, Neklason DW, Burt RW (2010): Hereditary and familial colon cancer. Gastroenterology 138, 2044-2058

Jess T, Gamborg M, Matzen P, Munkholm P, Sørensen TIA (2005): Increased risk of intestinal cancer in Crohn's disease: a meta-analysis of population-based cohort studies. Am J Gastroenterol $\underline{100}, 2724-2729$

Jin X, Moskophidis D, Mivechi NF (2011): Heat shock transcription factor 1 is a key determinant of HCC development by regulating hepatic steatosis and metabolic syndrome. Cell Metab $\underline{14}$, 91-103

Jolly C, Morimoto R, Robert-Nicoud M, Vourc'h C (1997): HSF1 transcription factor concentrates in nuclear foci during heat shock: relationship with transcription sites. J Cell Sci 110, 29352941

Kaiser AM, Attardi LD (2018): Deconstructing networks of p53-mediated tumor suppression in vivo. Cell Death Differ 25, 93-103

Kamal A, Thao L, Sensintaffar J, Zhang L, Boehm MF, Fritz LC, Burrows FJ (2003): A high-affinity conformation of Hsp90 confers tumour selectivity on Hsp90 inhibitors. Nature 425 , $407-$ 410

Kastan MB, Onyekwere O, Sidransky D, Vogelstein B, Craig RW (1991): Participation of p53 Protein in the Cellular Response to DNA Damage. Cancer Res $\underline{51}$, 6304-6311

Khosravi R, Maya R, Gottlieb T, Oren M, Shiloh Y, Shkedy D (1999): Rapid ATM-dependent phosphorylation of MDM2 precedes p53 accumulation in response to DNA damage. Proc Natl Acad Sci U S A $\underline{96}, 14973-14977$

Kirkegaard H, Johnsen NF, Christensen J, Frederiksen K, Overvad K, Tjønneland A (2010): Association of adherence to lifestyle recommendations and risk of colorectal cancer: a prospective Danish cohort study. BMJ $\underline{341}$, c5504 
Kline MP, Morimoto RI (1997): Repression of the heat shock factor 1 transcriptional activation domain is modulated by constitutive phosphorylation. Mol Cell Biol 17, 2107-2115

Laemmli UK (1970): Cleavage of structural proteins during the assembly of the head of bacteriophage T4. Nature 227, 680-685

Li D, Marchenko ND, Schulz R, Fischer V, Velasco-Hernandez T, Talos F, Moll UM (2011): Functional inactivation of endogenous MDM2 and CHIP by HSP90 causes aberrant stabilization of mutant p53 in human cancer cells. Mol Cancer Res MCR 9, 577-588

Li D, Yallowitz A, Ozog L, Marchenko N (2014): A gain-of-function mutant p53-HSF1 feed forward circuit governs adaptation of cancer cells to proteotoxic stress. Cell Death Dis $\underline{5}$, e1194

Liersch T, Grade M, Gaedcke J, Varma S, Difilippantonio MJ, Langer C, Hess CF, Becker H, Ried T, Ghadimi BM (2009): Preoperative chemoradiotherapy in locally advanced rectal cancer: correlation of a gene expression-based response signature with recurrence. Cancer Genet Cytogenet 190, 57-65

Lièvre A, Bachet J-B, Le Corre D, Boige V, Landi B, Emile J-F, Côté J-F, Tomasic G, Penna C, Ducreux $\mathrm{M}$ et al. (2006): KRAS mutation status is predictive of response to cetuximab therapy in colorectal cancer. Cancer Res $\underline{66}$, 3992-3995

Malkin D, Li FP, Strong LC, Fraumeni JF, Nelson CE, Kim DH, Kassel J, Gryka MA, Bischoff FZ, Tainsky MA (1990): Germ line p53 mutations in a familial syndrome of breast cancer, sarcomas, and other neoplasms. Science 250, 1233-1238

Malumbres M (2014): Cyclin-dependent kinases. Genome Biol 15, 122

Malumbres M, Barbacid M (2001): To cycle or not to cycle: a critical decision in cancer. Nat Rev Cancer 1, 222-231

Mantovani F, Collavin L, Sal GD (2019): Mutant p53 as a guardian of the cancer cell. Cell Death Differ $\underline{26}, 199-212$

McMillan DR, Xiao X, Shao L, Graves K, Benjamin IJ (1998): Targeted distuption of heat shock transcription factor 1 abolishes thermotolerance and protection against heat-inducible apoptosis. J Biol Chem $\underline{273}, 7523-7528$

Mendillo ML, Santagata S, Koeva M, Bell GW, Hu R, Tamimi RM, Fraenkel E, Ince TA, Whitesell L, Lindquist S (2012): HSF1 drives a transcriptional program distinct from heat shock to support highly malignant human cancers. Cell $\underline{150}, 549-562$

Min JN, Huang L, Zimonjic DB, Moskophidis D, Mivechi NF (2007): Selective suppression of lymphomas by functional loss of Hsf1 in a p53-deficient mouse model for spontaneous tumors. Oncogene 26, 5086-5097

Momand J, Zambetti GP, Olson DC, George D, Levine AJ (1992): The mdm-2 oncogene product forms a complex with the p53 protein and inhibits p53-mediated transactivation. Cell $\underline{69}$, $1237-1245$

Muto T, Bussey HJ, Morson BC (1975): The evolution of cancer of the colon and rectum. Cancer $\underline{36}, 2251-2270$

Neckers L, Workman P (2012): Hsp90 molecular chaperone inhibitors: are we there yet? Clin Cancer Res Off J Am Assoc Cancer Res 18, 64-76 
Olive KP, Tuveson DA, Ruhe ZC, Yin B, Willis NA, Bronson RT, Crowley D, Jacks T (2004): Mutant p53 gain of function in two mouse models of Li-Fraumeni syndrome. Cell $\underline{119}, 847-860$

Olivier M, Hollstein M, Hainaut P (2010): TP53 mutations in human cancers: origins, consequences, and clinical use. Cold Spring Harb Perspect Biol 2, a001008

Ong S-E, Blagoev B, Kratchmarova I, Kristensen DB, Steen H, Pandey A, Mann M (2002): Stable isotope labeling by amino acids in cell culture, SILAC, as a simple and accurate approach to expression proteomics. Mol Cell Proteomics 1, 376-386

Oromendia AB, Dodgson SE, Amon A (2012): Aneuploidy causes proteotoxic stress in yeast. Genes Dev 26, 2696-2708

Parikh N, Hilsenbeck S, Creighton CJ, Dayaram T, Shuck R, Shinbrot E, Xi L, Gibbs RA, Wheeler DA, Donehower LA (2014): Effects of TP53 mutational status on gene expression patterns across 10 human cancer types. J Pathol 232, 522-533

Polager S, Ginsberg D (2008): E2F - at the crossroads of life and death. Trends Cell Biol 18, 528535

Riihimäki M, Hemminki A, Sundquist J, Hemminki K (2016): Patterns of metastasis in colon and rectal cancer. Sci Rep $\underline{6}, 1-9$

Ritossa F (1962): A new puffing pattern induced by temperature shock and DNP in drosophila. Experientia 18, 571-573

Sandqvist A, Björk JK, Akerfelt M, Chitikova Z, Grichine A, Vourc'h C, Jolly C, Salminen TA, Nymalm Y, Sistonen L (2009): Heterotrimerization of heat-shock factors 1 and 2 provides a transcriptional switch in response to distinct stimuli. Mol Biol Cell 20, 1340-1347

Santagata S, Hu R, Lin NU, Mendillo ML, Collins LC, Hankinson SE, Schnitt SJ, Whitesell L, Tamimi RM, Lindquist S, Ince TA (2011): High levels of nuclear heat-shock factor 1 (HSF1) are associated with poor prognosis in breast cancer. Proc Natl Acad Sci U S A $\underline{108}, 18378-18383$

Sarge KD, Murphy SP, Morimoto RI (1993): Activation of heat shock gene transcription by heat shock factor 1 involves oligomerization, acquisition of DNA-binding activity, and nuclear localization and can occur in the absence of stress. Mol Cell Biol 13, 1392-1407

Sauer R, Becker H, Hohenberger W, Rödel C, Wittekind C, Fietkau R, Martus P, Tschmelitsch J, Hager E, Hess CF et al. (2004): Preoperative versus postoperative chemoradiotherapy for rectal cancer. N Engl J Med 351, 1731-1740

Schulz R, Streller F, Scheel AH, Rüschoff J, Reinert M-C, Dobbelstein M, Marchenko ND, Moll UM (2014): HER2/ErbB2 activates HSF1 and thereby controls HSP90 clients including MIF in HER2-overexpressing breast cancer. Cell Death Dis $\underline{5}$, e980

Schulz-Heddergott R, Stark N, Edmunds SJ, Li J, Conradi L-C, Bohnenberger H, Ceteci F, Greten FR, Dobbelstein M, Moll UM (2018): Therapeutic ablation of gain-of-function mutant p53 in colorectal cancer inhibits Stat3-mediated tumor growth and invasion. Cancer Cell $\underline{34}, 298$ 314

Schwitalla S, Ziegler PK, Horst D, Becker V, Kerle I, Begus-Nahrmann Y, Lechel A, Rudolph KL, Langer R, Slotta-Huspenina J et al. (2013): Loss of p53 in enterocytes generates an inflammatory microenvironment enabling invasion and lymph node metastasis of carcinogen-induced colorectal tumors. Cancer Cell 23, $93-106$ 
Scott KL, Nogueira C, Heffernan TP, van Doorn R, Dhakal S, Hanna JA, Min C, Jaskelioff M, Xiao Y, Wu C-J et al. (2011): Proinvasion metastasis drivers in early-stage melanoma are oncogenes. Cancer Cell 므, 92-103

Shieh SY, Ikeda M, Taya Y, Prives C (1997): DNA damage-induced phosphorylation of p53 alleviates inhibition by MDM2. Cell $191,325-334$

Siegel RL, Miller KD, Jemal A (2018): Cancer statistics, 2018. CA Cancer J Clin 요, 7-30

Smith DF, Whitesell L, Nair SC, Chen S, Prapapanich V, Rimerman RA (1995): Progesterone receptor structure and function altered by geldanamycin, an hsp90-binding agent. Mol Cell Biol 15, 6804-6812

Solimini NL, Luo J, Elledge SJ (2007): Non-oncogene addiction and the stress phenotype of cancer cells. Cell $\underline{130}$, 986-988

Sottoriva A, Kang H, Ma Z, Graham TA, Salomon MP, Zhao J, Marjoram P, Siegmund K, Press MF, Shibata D, Curtis C (2015): A Big Bang model of human colorectal tumor growth. Nat Genet 47, 209-216

Tang Z, Dai S, He Y, Doty RA, Shultz LD, Sampson SB, Dai C (2015): MEK guards proteome stability and inhibits tumor-suppressive amyloidogenesis via HSF1. Cell 160, 729-744

Tibbetts RS, Brumbaugh KM, Williams JM, Sarkaria JN, Cliby WA, Shieh SY, Taya Y, Prives C, Abraham RT (1999): A role for ATR in the DNA damage-induced phosphorylation of p53. Genes Dev 13, 152-157

Tomasetti C, Marchionni L, Nowak MA, Parmigiani G, Vogelstein B (2015): Only three driver gene mutations are required for the development of lung and colorectal cancers. Proc Natl Acad Sci U S A $\underline{112}, 118-123$

Tripathy D, Bardia A, Sellers WR (2017): Ribociclib (LEE011): Mechanism of action and clinical impact of this selective cyclin-dependent kinase 4/6 inhibitor in various solid tumors. Clin Cancer Res Off J Am Assoc Cancer Res $\underline{23}$, 3251-3262

van der Sijp MPL, Bastiaannet E, Mesker WE, van der Geest LGM, Breugom AJ, Steup WH, Marinelli AWKS, Tseng LNL, Tollenaar RAEM, van de Velde CJH, Dekker JWT (2016): Differences between colon and rectal cancer in complications, short-term survival and recurrences. Int J Colorectal Dis $\underline{31}, 1683-1691$

Vassilev LT (2006): Cell cycle synchronization at the G2/M phase border by reversible inhibition of CDK1. Cell Cycle Georget Tex $\underline{5}$, 2555-2556

Vassilev LT, Vu BT, Graves B, Carvajal D, Podlaski F, Filipovic Z, Kong N, Kammlott U, Lukacs C, Klein C et al. (2004): In vivo activation of the p53 pathway by small-molecule antagonists of MDM2. Science $\underline{303}, 844-848$

Vogelstein B, Fearon ER, Hamilton SR, Kern SE, Preisinger AC, Leppert M, Nakamura Y, White R, Smits AM, Bos JL (1988): Genetic alterations during colorectal-tumor development. N Engl J Med $\underline{319}, 525-532$

Vu B, Wovkulich P, Pizzolato G, Lovey A, Ding Q, Jiang N, Liu J-J, Zhao C, Glenn K, Wen Y et al. (2013): Discovery of RG7112: A small-molecule MDM2 inhibitor in clinical development. ACS Med Chem Lett $\underline{4}, 466-469$

Westerheide SD, Anckar J, Stevens SM, Sistonen L, Morimoto RI (2009): Stress-inducible regulation of heat shock factor 1 by the deacetylase SIRT1. Science $\underline{323}, 1063-1066$ 
Whitesell L, Lindquist SL (2005): HSP90 and the chaperoning of cancer. Nat Rev Cancer $\underline{5}, 761-772$

Winawer SJ, Zauber AG, Ho MN, O’Brien MJ, Gottlieb LS, Sternberg SS, Waye JD, Schapiro M, Bond JH, Panish JF (1993): Prevention of colorectal cancer by colonoscopic polypectomy. The National Polyp Study Workgroup. N Engl J Med 329, 1977-1981

Wu X, Bayle JH, Olson D, Levine AJ (1993): The p53-mdm-2 autoregulatory feedback loop. Genes Dev 7, 1126-1132

Yang L, Wang S, Lee JJ-K, Lee S, Lee E, Shinbrot E, Wheeler DA, Kucherlapati R, Park PJ (2019): An enhanced genetic model of colorectal cancer progression history. Genome Biol 20, 168

Zauber AG, Winawer SJ, O’Brien MJ, Lansdorp-Vogelaar I, van Ballegooijen M, Hankey BF, Shi W, Bond JH, Schapiro M, Panish JF et al. (2012): Colonoscopic polypectomy and long-term prevention of colorectal-cancer deaths. N Engl J Med $\underline{366}$, 687-696

Zentrum für Krebsregisterdaten im Robert Koch-Institut (Hrsg.): Bericht zum Krebsgeschehen in Deutschland 2016. Robert Koch-Institut, Berlin 2019

Zou J, Guo Y, Guettouche T, Smith DF, Voellmy R (1998): Repression of heat shock transcription factor HSF1 activation by HSP90 (HSP90 complex) that forms a stress-sensitive complex with HSF1. Cell $\underline{94}$, 471-480 


\section{Danksagung}

Ich möchte mich besonders bei Dr. Ramona Schulz-Heddergott für ihre Betreuung, Anleitung und Hilfe bei der praktischen Arbeit im Labor und der gesamten Umsetzung meines Promotionsprojektes bedanken. Ebenso möchte ich mich bei ihr für die Überlassung des Themas meiner Doktorarbeit bedanken.

Mein Dank gilt auch Prof. Dr. Matthias Dobbelstein für die Möglichkeit, dieses Projekt in seiner Arbeitsgruppe bearbeiten zu dürfen.

Alle Teammitglieder der Molekularen Onkologie haben mich während meiner Arbeit im Labor unterstützt und zum Gelingen dieser Arbeit beigetragen.

Ich danke der Universitätsmedizin Göttingen für die Förderung im Rahmen des JacobHenle-Programms für experimentelle Medizin. 